\title{
BIONOMICS OF THE POOR-COD (GADUS MINUTUS L.) IN THE PLYMOUTH AREA
}

\author{
By M. Devidas Menon, B.Sc., M.A. \\ Assistant Director of Fisheries, Madras \\ From the Plymouth Laboratory
}

(Plates I and II and Text-figs. I-I6)

\section{CONTENTS}

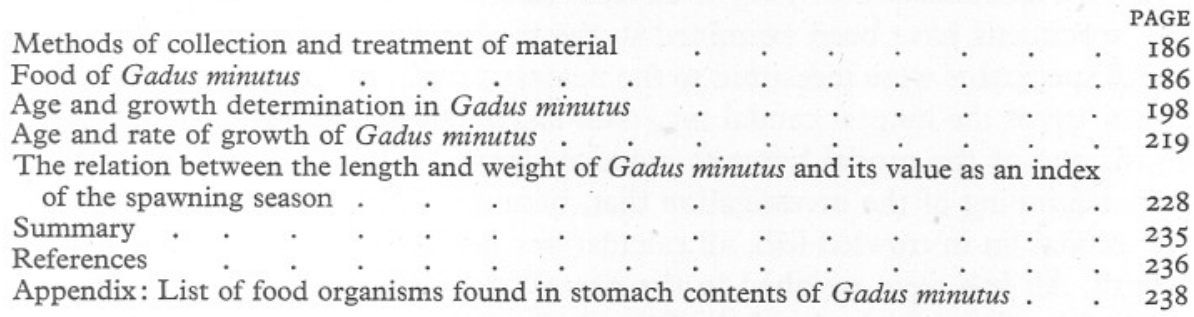

The Poor-Cod, Gadus minutus L., is a very common gadoid off Plymouth, 'probably the commonest gadoid in the trawling grounds' (Mar. Biol. Assoc., I93I). McIntosh \& Masterman (I897) and Ehrenbaum(I9OI-IO) have described its development, and Schmidt (1902-07) has given a very detailed description of its larvae and post-larvae. Barring these, and a few other scattered works on its systematics, no detailed study has been made so far on the general lifehistory of G. minutus. The scope of this work is limited to the food, age and rate of growth, the length-weight relation and the spawning period of the Plymouth poor-cod population. The great availability of this fish in the Plymouth area has made the problem of collection of material for this study quite easy.

I am greatly indebted to Mr F. S. Russell and Mr E. Ford for suggesting this problem to me and for giving me much help and criticism in my work. I am extremely grateful to $\mathrm{Mr}$ G. A. Steven for kindly going through the manuscript of this paper and for offering valuable criticisms and suggestions for its improvement. My thanks are especially due to Dr T. J. Hart who encouraged and helped me most generously throughout my work. I am grateful to Mr P. G. Corbin for lending me several post-larval specimens of Gadus minutus from his collections and to Mr G. M. Spooner for kindly identifying the amphipods ${ }^{1}$ contained in the food of the fish. I am grateful to Dr M. V. Lebour and Dr D. P. Wilson for helping me in the identification of some of the crustaceans and polychaetes in the qualitative analysis of the food of the fish. To Mr F. G. C. Ryder my thanks are due for making the otolith measuring scale and the vertical projector. Finally my thanks are due to the

1 See also p. I93 of this fournal. 
entire technical staff of the laboratory and the crew of the laboratory vessels for their help in collecting the specimens.

The work described here was undertaken while I was holding the Madras Government Scholarship.

\section{Methods of Collection and Treatment of Material}

The whole material for this study has been collected from the Plymouth area outside the breakwater and around the Eddystone grounds by trawling from the Laboratory research vessels Sabella and Sula. The total number of fish thus collected and analysed is 5003 of all sizes ranging from 5 to $25 \mathrm{~cm}$. Nearly all the specimens have been examined in the fresh state.

All specimens were measured to the nearest $5 \mathrm{~mm}$., from the tip of the snout to the tip of the longest caudal ray (total length) and from the tip of the snout to the end of the caudal hypural (standard length). ${ }^{1}$ It was apparent from the very beginning of the investigation that, because of the tearing and fraying of the caudal fin in trawled fish, all calculations had to be based on the standard length. All fish were weighed to the nearest gram in a Salter spring balance. The scales from the body of the fish which still retained them after trawling were removed by a scalpel and preserved in tissue-paper envelopes for later study. After measurements the specimens were dissected, the sexes were noted and the stomachs were then cut out and preserved in $5 \%$ sea-water formalin, sorted in $5 \mathrm{~cm}$. body-length groups. A few random samples of specimens were boiled in toto. With other samples only the heads were boiled, for collecting the supra-occipital crest, which is the index that has been used for determination of age and rate of growth in this fish. During the early period of this study the specimens were collected by the ordinary otter trawl, and naturally a great amount of selective sampling by the gear has occurred. Towards the later period of the study Mr P. G. Corbin collected for me a fair number of O-group and I-group specimens of $G$. minutus by means of the otter trawl with attached sprat-net cod-end. The otoliths were collected by incising the skull dorsally behind the orbits and also by boiling the heads. All the otoliths were preserved in tissue-paper envelopes. A few specimens of the O-group from random samples were preserved in $5 \%$ sea-water formalin for later alizarine staining.

\section{Food OF GADUS MINUTUS}

The food has been analysed qualitatively and volumetrically. The stomachs of each $5 \mathrm{~cm}$. length group of fish were kept separate as they were collected. Each stomach was subsequently dissected and the contents washed out into a Petri dish. The different organisms were sorted and their volumes measured. The volumes were determined by the displacement method in a measuring cylinder graduated to O.I c.c. The organisms were identified to species whenever possible. But the effect of digestion often rendered only the generic or family

1 All the lengths of the fish given in this paper are standard lengths, unless otherwise stated. 
characters recognizable. G. minutus, like several other gadoids, sometimes everts its stomach and disgorges its contents during the course of trawling. But this occurred only in $0.8 \%$ of the stomachs analysed, and so could be assumed to have not interfered with the general conclusions. Another factor which also has to be taken into account in the analysis of the food organisms is the fortuitous snatching of other organisms while the fish are in the trawl. When the stomachs contained a few organisms which were quite fresh in appearance and showed no evidence of action of the digestive juices, their presence must be disregarded because of this habit, which is well known among many other fishes.

In the first few months of the study, the fish were grouped into $5 \mathrm{~cm}$. groups for food analysis. It was soon found that there was virtually no apparent difference in the food ingested by the various adolescent year groups and so the work was done on two separate groups only; O-group and all the rest together.

In counting the food organisms several precautions had to be taken to avoid the numerical difficulties arising out of the pieces and fragments resulting from the different stages of digestion. The method suggested by Brown \& Cheng (I946) was followed. For amphipods and polychaetes the heads were counted and only recognizable specimens of other organisms were counted, the residue being treated as 'Galathea remains', 'Processa remains, Fish remains', etc. Volumetric analysis helps to tide over this difficulty to a great extent.

\section{Food of the I- to V-Year Groups}

G. minutus of year-groups I to $\mathrm{V}$ is primarily a crustacean feeder, feeding on the bottom Crustacea. Day (I880-84) found that 'they live on small crustaceous animals...' Thompson (I856) noticed chiefly Crustacea in their stomachs: 'In one was a full grown Pagurus bernhardus and fragments of marine plants also have occurred.' Fries et al. (I892) also make a more or less similar statement that 'it lives on small victims, consisting chiefly of crustaceans and mollusks'. In studying the food of the North Sea fishes, Franz (I9I0) found that the food of Gadus minutus consisted of fish (Drepanopsetta), crustaceans (Pandalus and Eupagurus bernhardii) and echinoderms.

In the analysis of the 3909 stomachs of Plymouth Gadus minutus (I to V yeargroups) it was found that crustaceans form by far the greater part of the food consumed. Nine types of organisms form the principal food material of this fish in the Plymouth area. In the volumetric analysis (Tables I and II) these have been treated separately, and all the rest have been lumped together as 'others'. These nine principal organisms and their proportions of the total volume of food during the period under survey were as follows:

$\begin{array}{lrll}\text { Processa canaliculata } & 21 \% & \text { Porcellana spp. } & 6 \% \\ \text { Fish } & 20 \% & \text { Crangonidae } & 6 \% \\ \text { Polychaeta } & 8 \% & \text { Amphipoda } & 3 \% \\ \text { Portunus spp. } & 8 \% & \text { Mysidacea and Euphausiacea } & 3 \% \\ \text { Galathea spp. } & 7 \% & & \end{array}$


Of the remaining $18 \%$ constituting the 'others', crustaceans formed $13 \%$. Thus the total percentage of crustaceans consumed by the fish is 67 by volume.

When the number of fish that ingested particular organisms is considered, a different picture is obtained (Table III). Processa canaliculata occurs in more stomachs than any of the other food organisms, whose percentage frequency of occurrence is shown in the following list. Amphipods come second on the list, although as we have seen, they formed only a small percentage of the total volume of food. Conversely, Crangonidae and Porcellana spp., though forming a fair amount of the total volume of food, were found in a few fishes only. The reason is, of course, that whereas one Porcellana measured some 0.2 c.c., it requires 5-7 Ampelisca spinipes or 30-50 Apherusa henneguyi to make up the same volume.

\begin{tabular}{|c|c|c|c|}
\hline \multicolumn{4}{|c|}{$29 \%$ of the stomachs contained Process a canaliculata } \\
\hline $23 \%$ & ” & " & Amphipoda \\
\hline $16 \%$ & 川 & ” & Fish \\
\hline $16 \%$ & " & " & Galathea spp. \\
\hline $14 \%$ & " & " & Polychaeta \\
\hline $10 \%$ & ” & " & Portunus spp. \\
\hline $9 \%$ & ” & \% & Porcellana spp. \\
\hline $8 \%$ & " & " & Mysidacea and Euphausiacea \\
\hline $8 \%$ & " & , & Crangonidae \\
\hline
\end{tabular}

The average volume of food per stomach for the period of investigation was 0.5 c.c. The percentage of empty stomachs (without taking the number of everted stomachs into consideration) was I0.5. The average volume of food per stomach in the respective months during the period of study was as follows:

$\begin{array}{llll}\text { I948 } & \text { c.c. } & \text { I949 } & \text { c.c. } \\ \text { Apr. } & 0.57 & \text { Jan. } & 0.34 \\ \text { May } & 0.59 & \text { Feb. } & 0.43 \\ \text { June } & 0.54 & \text { Mar. } & 0.42 \\ \text { July } & 0.73 & \text { Apr. } & 0.69 \\ \text { Aug. } & 0.46 & \text { May } & 0.77 \\ \text { Sept. } & 0.49 & \text { June } & 0.59 \\ \text { Oct. } & 0.47 & & \\ \text { Nov. } & 0.42 & & \\ \text { Dec. } & 0.46 & & \end{array}$

Because the fish were collected at about the same time of the day throughout the investigation, it is probable that most of the food in their stomachs had undergone the same amount of digestion. The volume of food in the stomachs does not represent the volume consumed during feeding, because different food organisms will be digested at different rates. But on the general assumption that the food in most stomachs had reached the same state of digestion the results can roughly be treated as a fair guide to the feeding activity of the fish. On this basis three definite phases of feeding activity could be distinguished. 
Table I. Volumetric Analysis of the Stomach Contents Per ioo Stomachs (Volumes in c.c.)

\begin{tabular}{|c|c|c|c|c|c|c|c|c|c|c|c|c|c|c|c|}
\hline \multirow[b]{2}{*}{ Food organisms } & \multicolumn{9}{|c|}{1948} & \multicolumn{6}{|c|}{ I949 } \\
\hline & Apr. & May & June & July & Aug. & Sept. & Oct. & Nov. & Dec. & Jan. & Feb. & Mar. & Apr. & May & June \\
\hline Fish & $2 \cdot 4$ & 24.0 & 28.0 & $36 \cdot 1$ & $2 \cdot 6$ & $3 \cdot 1$ & $4 \cdot 7$ & $3 \cdot 2$ & $5 \cdot 8$ & $2 \cdot 8$ & $8 \cdot 6$ & $6 \cdot 9$ & $9 \cdot 8$ & $I 2 \cdot I$ & $19 \cdot 3$ \\
\hline Amphipoda & $2 \cdot 0$ & $2 \cdot 6$ & $3 \cdot 2$ & $2 \cdot 0$ & $1 \cdot 7$ & $\mathrm{I} \cdot 4$ & 0.7 & $\mathrm{I} \cdot 7$ & $1 \cdot 5$ & 0.6 & 0.5 & $\mathrm{I} \cdot 0$ & I. 4 & I. 4 & I. 7 \\
\hline Polychaeta & $16 \cdot 0$ & $4 \cdot 6$ & $\mathrm{I} \cdot 3$ & $I \cdot 5$ & $I \cdot 0$ & $6 \cdot 7$ & $2 \cdot I$ & $\mathrm{I} \cdot 9$ & 2.5 & $4 \cdot I$ & $5 \cdot 3$ & $5 \cdot 5$ & $2 \cdot 4$ & $2 \cdot 9$ & $I \cdot 2$ \\
\hline Schizopoda (sens, lat.) & $2 \cdot 4$ & 3.0 & $2 \cdot 8$ & $1 \cdot 0$ & $I \cdot O$ & $I \cdot 0$ & $I \cdot O$ & $\mathrm{I} \cdot 0$ & $I \cdot 0$ & $1 \cdot 0$ & 0.5 & 0.4 & 0.8 & $\mathrm{I} \cdot 4$ & $2 \cdot 2$ \\
\hline Processa canaliculata & $6 \cdot 2$ & I 4.0 & $7 \cdot 4$ & II 5 & $16 \cdot 7$ & $14 \cdot 2$ & $15 \cdot 7$ & $10 \cdot 8$ & $9 \cdot 6$ & $5 \cdot 5$ & $7 \cdot 6$ & II 6 & $5 \cdot 6$ & $5 \cdot 6$ & $16 \cdot 3$ \\
\hline Crangonidae & $8 \cdot I$ & $2 \cdot 2$ & $2 \cdot 0$ & $3 \cdot 0$ & $2 \cdot 9$ & $2 \cdot 1$ & $\mathbf{I} \cdot \mathbf{I}$ & $4 \cdot 5$ & $5 \cdot 6$ & $3 \cdot 3$ & $\mathrm{I} \cdot 8$ & 0.7 & $\mathrm{I} \cdot \mathrm{O}$ & $2 \cdot 6$ & $I \cdot I$ \\
\hline Galathea spp. & $2 \cdot 4$ & $3 \cdot 6$ & $4 \cdot 0$ & $4 \cdot 3$ & $3 \cdot 8$ & $2 \cdot 2$ & $3 \cdot I$ & $\mathrm{I} \cdot 3$ & 3.5 & $I \cdot 9$ & $3 \cdot 2$ & 3.8 & $14 \cdot 2$ & $4 \cdot 6$ & $4 \cdot 8$ \\
\hline Porcellana spp. & $I \cdot I$ & 0.5 & $2 \cdot 1$ & $8 \cdot 3$ & $2 \cdot 5$ & $2 \cdot 3$ & 0.7 & $5 \cdot \mathrm{I}$ & 5.0 & $I \cdot 4$ & 2.5 & $3 \cdot 6$ & 3.4 & $3 \cdot 8$ & $2 \cdot 0$ \\
\hline Portunus spp. & 3.9 & $2 \cdot 2$ & I. 5 & $3 \cdot 4$ & $5 \cdot 4$ & $5 \cdot 7$ & $4 \cdot \mathrm{I}$ & $2 \cdot 9$ & $3 \cdot I$ & 3.4 & $3 \cdot I$ & 2.9 & $6 \cdot 5$ & $5 \cdot 2$ & $6 \cdot 1$ \\
\hline Others & $12 \cdot 0$ & $2 \cdot 0$ & $I \cdot 6$ & $1 \cdot 6$ & $8 \cdot 4$ & $9 \cdot 9$ & I3.9 & $9 \cdot 9$ & $8 \cdot 2$ & $9 \cdot 7$ & $9 \cdot 4$ & $5 \cdot 5$ & $24 \cdot 2$ & $36 \cdot 9$ & $4 \cdot 6$ \\
\hline Total volume & $56 \cdot 5$ & $58 \cdot 7$ & 53.9 & $72 \cdot 7$ & $46 \cdot 0$ & $48 \cdot 6$ & $47 \cdot I$ & $42 \cdot 3$ & $45^{\cdot 8}$ & $33 \cdot 7$ & $42 \cdot 5$ & $4 I \cdot 9$ & $69 \cdot 3$ & $76 \cdot 5$ & $59 \cdot 3$ \\
\hline No. of stomachs examined & 160 & 486 & 470 & 195 & 242 & 266 & 189 & 215 & 155 & 189 & 308 & 330 & 302 & 252 & 150 \\
\hline No. of empty stomachs & 20 & 54 & $6 \mathrm{I}$ & 21 & 18 & I4 & 15 & I0 & 16 & 24 & 52 & 40 & 26 & 18 & 16 \\
\hline
\end{tabular}

Table II. Percentage Composition of the Stomach Contents

\begin{tabular}{|c|c|c|c|c|c|c|c|c|c|c|c|c|c|c|c|}
\hline \multirow{3}{*}{$\begin{array}{l}\text { Food organism } \\
\text { Fish }\end{array}$} & \multicolumn{9}{|c|}{ I948 } & \multicolumn{6}{|c|}{ I949 } \\
\hline & Apr. & May & June & July & Aug. & Sept. & Oct. & Nov. & Dec. & Jan. & Feb. & Mar. & Apr. & May & June \\
\hline & $4 \cdot 2$ & $40 \cdot 9$ & $5 \mathrm{I} \cdot 9$ & $49 \cdot 7$ & 5 & $6 \cdot 4$ & $10 \cdot 0$ & $7 \cdot 5$ & $12 \cdot 7$ & $8 \cdot 3$ & $20 \cdot 2$ & 16.5 & $14 \cdot I$ & I5.8 & $3 I \cdot 6$ \\
\hline Amphipoda & 0 & 4.4 & $5 \cdot 9$ & 3 & & $2 \cdot 9$ & I. 5 & 4 & 3 & I & $I \cdot 2$ & $2 \cdot 4$ & $2 \cdot 0$ & & $2 \cdot 9$ \\
\hline Polychaeta & 28 & 4. & 2 . & $2 \cdot I$ & $2 \cdot 2$ & 13.8 & $4 \cdot 5$ & 4.5 & 5 & $12 \cdot 2$ & 12.5 & I3. I & 3.5 & & $2 \cdot 0$ \\
\hline oda (sens. lat.) & $4 \cdot 2$ & $5: 1$ & $5 \cdot 2$ & I. 4 & $2 \cdot 2$ & $2 \cdot I$ & $2 \cdot 1$ & 2 . & 2 & $2 \cdot 9$ & $I \cdot 2$ & $\mathrm{I} \cdot \mathrm{O}$ & I. & $\mathbf{I}$ & $4 \cdot I$ \\
\hline analiculata & II. & 23.9 & 13.7 & 15.8 & $36 \cdot 3$ & $29 \cdot 2$ & $33 \cdot 3$ & 25.5 & $2 \mathrm{I}$ & I6. 4 & 17.9 & $27 \cdot 7$ & $8 \cdot I$ & 7 & 27.5 \\
\hline onidae & 14.2 & 3.7 & 3.7 & $4 \cdot 2$ & $6 \cdot 3$ & $4 \cdot 3$ & & 10 & & 9.9 & $4 \cdot 2$ & I. 7 & & & $\mathrm{I} \cdot 9$ \\
\hline Galathea & $4 \cdot 2$ & $6 \cdot 1$ & $7 \cdot 4$ & 5.9 & $8 \cdot 3$ & 4.5 & $6 \cdot 6$ & $3 \cdot I$ & $7 \cdot 6$ & $5 \cdot 6$ & $7 \cdot 5$ & $9 \cdot \mathrm{I}$ & 20.5 & 6.0 & $8 \cdot I$ \\
\hline Porcellana & $\mathrm{I} \cdot 8$ & 0.9 & 3.9 & II 4 & $5 \cdot 4$ & 4.7 & I. 5 & $12 \cdot I$ & ro & $4 \cdot 2$ & 5.9 & 8.6 & 4.9 & $5 \cdot 0$ & 3.4 \\
\hline Ports & $7 \cdot I$ & $3 \cdot 6$ & $2 \cdot 8$ & 4.7 & & II. 7 & $8 \cdot 7$ & 6.9 & 6 & $10 \cdot 2$ & & $6 \cdot 9$ & $9 \cdot 4$ & $6 \cdot 8$ & 10.3 \\
\hline Others & $2 \mathrm{I} \cdot 3$ & 3.4 & 3.0 & $2 \cdot 2$ & $18 \cdot 2$ & $20 \cdot 4$ & 29.5 & $23 \cdot 4$ & 17.9 & $29 \cdot I$ & $22 \cdot \mathrm{I}$ & $13 \cdot I$ & 34.9 & $48 \cdot 2$ & $7 \cdot 8$ \\
\hline
\end{tabular}

Table III. Percentage of Prevalence of the Food Organisms in the Stomachs Examined

I948

Food organism
Fish
Amphipoda
Polychaeta
Schizopoda (sens. lat.)
Processa
Crangonidae
Galathea
Porcellana
Portunus

\begin{tabular}{|c|c|c|c|c|c|c|c|c|}
\hline Apr. & May & June & July & Aug. & Sept. & Oct. & Nov. & Dec. \\
\hline $\begin{array}{l}9 \cdot 4 \\
9 \cdot 4\end{array}$ & $\begin{array}{l}27 \cdot 2 \\
39 \cdot 5\end{array}$ & $\begin{array}{l}35.0 \\
36.6\end{array}$ & $\begin{array}{l}61 \cdot 5 \\
27 \cdot 7\end{array}$ & $\begin{array}{r}5.4 \\
20 \cdot 7\end{array}$ & $\begin{array}{r}3.8 \\
15.0\end{array}$ & $\begin{array}{l}9.0 \\
8.5\end{array}$ & $\begin{array}{l}\text { II } \cdot 7 \\
23 \cdot 3\end{array}$ & $\begin{array}{r}11 \cdot 6 \\
9.0\end{array}$ \\
\hline $43 \cdot 8$ & I9. I & 4.7 & $6 \cdot 2$ & $4 \cdot I$ & $23 \cdot 3$ & $5 \cdot 8$ & 14.0 & 10.3 \\
\hline 12.5 & $30 \cdot 3$ & II $\cdot I$ & $\begin{array}{r}8.7 \\
\end{array}$ & $\begin{array}{r}9 \cdot \mathrm{I} \\
9.9 .\end{array}$ & 6.0 & 4.2 & 9.3 & $5 \cdot 2$ \\
\hline $28 \cdot I$ & 34.6 & $43 \cdot 8$ & $24 \cdot 6$ & $48 \cdot 8$ & $45^{\circ} \mathrm{I}$ & 26.5 & 34.9 & $22 \cdot 6$ \\
\hline 12.5 & $7 \cdot 8$ & $7 \cdot 2$ & II. 8 & 9.9 & $8 \cdot 3$ & $3 \cdot 7$ & $9 \cdot 3$ & $7 \cdot 7$ \\
\hline $9 \cdot 4$ & I6.7 & I2. I & I3.8 & 14.5 & 15.8 & $12 \cdot 2$ & 14.0 & 13.5 \\
\hline $3 \cdot I$ & 2.9 & $2 \cdot 3$ & $7 \cdot 7$ & $4 \cdot I$ & 6.0 & $4 \cdot 2$ & 16.3 & 12.3 \\
\hline $9 \cdot 4$ & $8 \cdot 8$ & 6.6 & 10.8 & I6.8 & $5 \cdot 3$ & $9 \cdot 0$ & $7 \cdot 0$ & II 6 \\
\hline
\end{tabular}

I949

\begin{tabular}{|c|c|c|c|c|c|}
\hline Jan. & Feb. & Mar. & Apr. & May & Jun \\
\hline $\begin{array}{l}6 \cdot 3 \\
0.5\end{array}$ & $\begin{array}{r}15.6 \\
5.8\end{array}$ & 13.3 & 9.4 & $\begin{array}{r}6.0 \\
16.3\end{array}$ & $\begin{array}{l}14 \cdot 6 \\
27 \cdot 0\end{array}$ \\
\hline $\begin{array}{r}9.5 \\
23.8\end{array}$ & $\begin{array}{r}5.8 \\
12.3\end{array}$ & $\begin{array}{r}10.9 \\
9.7\end{array}$ & $\begin{array}{r}8.7 \\
10.3\end{array}$ & $\begin{array}{l}16 \cdot 3 \\
18 \cdot 3\end{array}$ & $7 \cdot 2$ \\
\hline $4 \cdot 2$ & 5 & $3 \cdot 6$ & I. 7 & $I \cdot 2$ & $9 \cdot 3$ \\
\hline $20 \cdot 6$ & II $\cdot 7$ & I9.4 & $13 \cdot 2$ & $20 \cdot 6$ & 38.5 \\
\hline $6 \cdot 3$ & 3.9 & $4 \cdot 8$ & 5.0 & $\mathrm{I} 2 \cdot 3$ & $8 \cdot 2$ \\
\hline 7.9 & $7 \cdot 1$ & $3 \mathrm{I} \cdot 5$ & 33.7 & $24 \cdot 2$ & I0.7 \\
\hline $7 \cdot$ & II $\cdot 0$ & $18 \cdot 2$ & $16 \cdot 2$ & I 4.7 & $5 \cdot 6$ \\
\hline 15.9 & 4.5 & $4 \cdot 8$ & I $2 \cdot 3$ & 10.7 & $9 \cdot 3$ \\
\hline
\end{tabular}


The average volume of food per stomach has been plotted against the respective months as a curve (Text-fig. I). The spawning period of the fish is from February to May. Text-fig I makes clear that there was a period of very active feeding from April to July, synchronizing with the end of spawning and the period just after spawning when the fish was recovering from the strain. This was followed by a period, from August to December, when the average volume of food per stomach was more or less the same as the annual average volume per stomach. For practical purposes this period could be

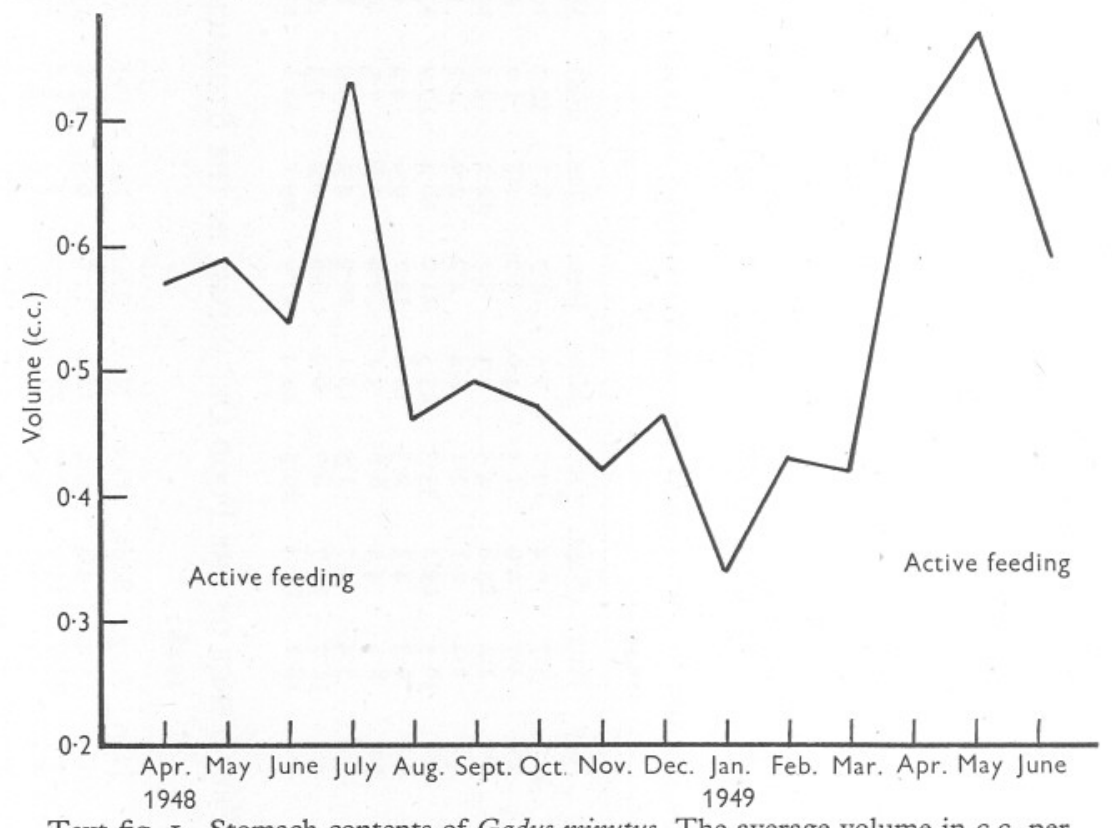

Text-fig. I. Stomach contents of Gadus minutus. The average volume in c.c. per stomach in successive months.

distinguished as 'the period of average feeding', and it coincided with the latter part of summer, autumn and early part of winter. This period was succeeded by a period of 'low feeding'. During the months just prior to spawning and during the earlier part of the spawning period, i.e. from the latter part of December to early part of March, the abdominal cavity of the fish is very much distended and filled by the gonads. At this time the fish shows a much reduced feeding activity. Just after spawning the fish feeds voraciously. Newly spawned and fully spent specimens with their stomachs gorged with food were common in the April and May samples. In May 1949 two specimens, measuring 19.5 and $20 \mathrm{~cm}$., had ingested 6 and 5 c.c. of food material respectively. Both were emaciated and completely spent, and in each of them the supra-occipital stood out like a skin-covered crest on the top of the head. Such specimens were frequent in April and May. 
This conclusion is substantiated further by the number of empty stomachs occurring in the various months. The percentage of empty stomachs that occurred in the respective months are given below:

$\begin{array}{lrlr}\text { I948 } & \% & \text { I949 } & \% \\ \text { Apr. } & \text { I0.0 } & \text { Jan. } & \text { I2.7 } \\ \text { May } & \text { II. } & \text { Feb. } & \text { I7.5 } \\ \text { June } & 13 \cdot 0 & \text { Mar. } & \text { I2.1 } \\ \text { July } & 10 \cdot 5 & \text { Apr. } & 8 \cdot 6 \\ \text { Aug. } & 7 \cdot 5 & \text { May } & 7 \cdot 1 \\ \text { Sept. } & 5 \cdot 3 & \text { June } & \text { I0.6 } \\ \text { Oct. } & 7 \cdot 5 & & \\ \text { Nov. } & 5 \cdot 0 & & \\ \text { Dec. } & 10 \cdot 0 & & \end{array}$

The percentage of fish with empty stomachs was greatest just prior to, and during, the spawning period. During the period of growth, i.e. from August to November, the percentage was small. Almost all the fish which had empty stomachs during the spawning months were fully mature specimens with ripe and enlarged gonads about to spawn.

The percentage of empty stomachs, if calculated for the three different periods of feeding activity, can be seen to average 10. I \% during the period of active feeding from April to July, $7 \cdot 1 \%$ during the period of 'average feeding' from August to December, and I4.I \% during the period of low feeding from January to March.

Considering the part that each of the principal food organisms plays in the food and feeding of the poor-cod, we find that Processa canaliculata is the commonest organism, forming a very large proportion of the food throughout the year. It is most predominant in the months following spawning, especially from August to November (Text-fig. 2A).

In August and September I 948 as many as $46 \%$, or nearly half the number of fish analysed, had ingested Processa. Only a few had this organism in their stomachs during the spawning period.

Fish. Fish forms an important portion of the'diet of the poor-cod during May, June and July (Text-fig. 2B). Owing to advanced digestion it was not possible to identify the species of fish consumed in some stomachs. The otoliths were the best aid to identification. The fish found in the stomachs of the poor-cod were:

Crystallogobius nillsoni May, June, July 1948

Callionymus sp.

Trigla sp.

Ctenolabrus sp.

February, March, April 1949

Gadus minutus?

In July I948 as many as 6I \% of the stomachs analysed had fish in them. In June of the same year about $35 \%$ had ingested fish. 

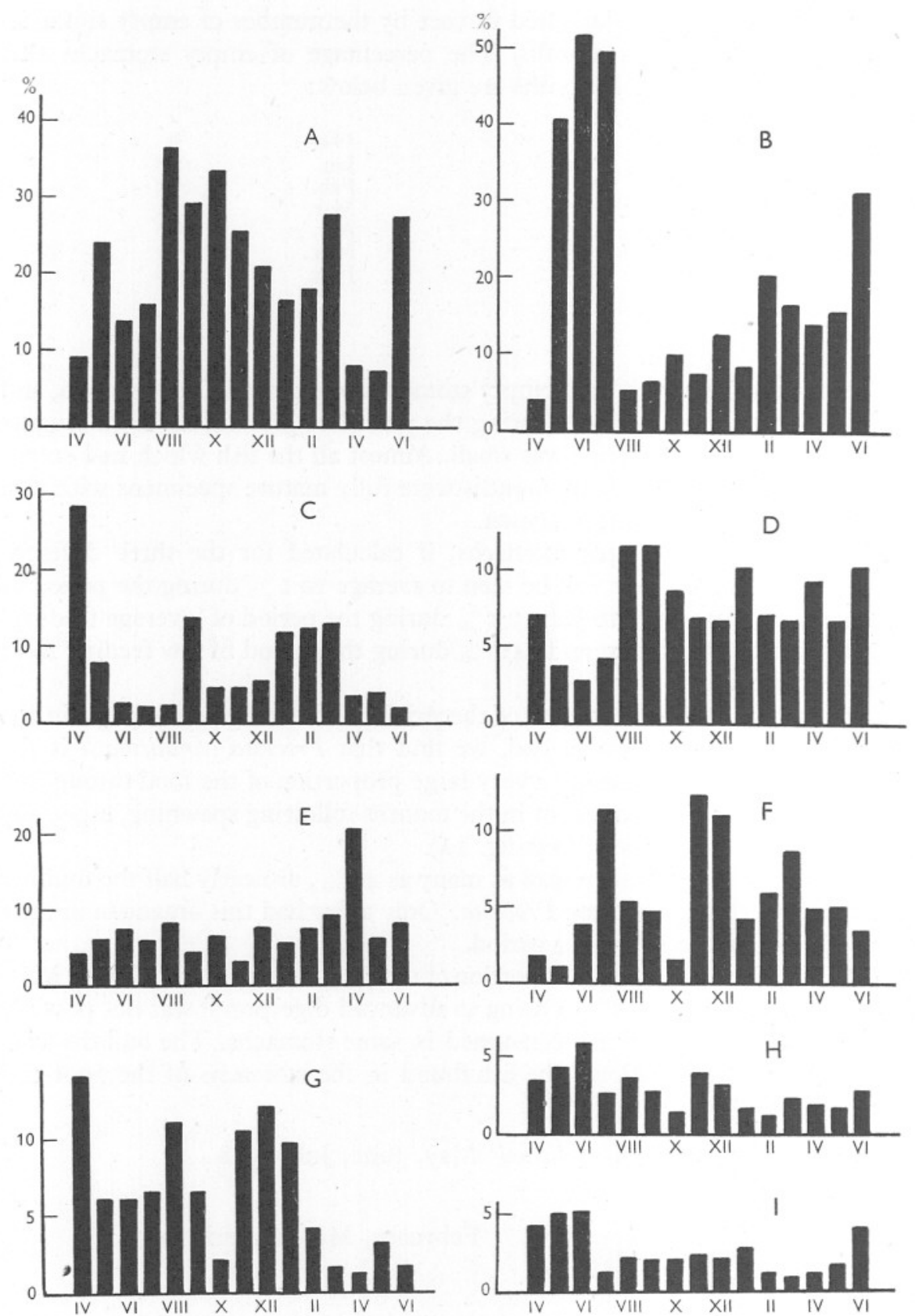

Text-fig. 2. Histograms showing the relative percentage composition of the nine principal food organisms taken by Gadus minutus in the different months during 1948-49. For comparison all values are expressed as the percentage in volume of Ioo c.c. of food material. A, Processa canaliculata; B, fish; C, Polychaeta; D, Portunus sp.; E, Galathea sp.; F, Porcellana sp.; G, Crangonidae; H, Amphipoda; I, mysids and euphausiids. 
Polychaeta. Polychaetes have presented considerable difficulty in identification as they were in an advanced state of digestion in most of the stomachs. They were largely present in the food during the spawning months (Text-fig. 2 C). Amphitrite sp. and Goniada sp. formed the commonest of the identifiable worms in the food. In September 1948 there was one stomach which contained a Pallasia murata with a portion of the worm in a part of the tube. In April I 948 nearly $40 \%$ of the stomachs examined had polychaetes in them.

Portunus sp. Portunidae were present in the food throughout, forming a fairly consistent proportion of it (Text-fig. 2D). In August and September I 948 they formed nearly I2 \% of the food in the stomachs analysed. The common species were $P$. pusillus and $P$. depurator. In August 1948 about $17 \%$ of the stomachs analysed had Portunidae.

Galathea sp. Galatheids form an important element of the crustacean part of the food, especially during the latter part of the spawning period, from March to May (Text-fig. 2E). Many of the spent fish in April I949 had their stomachs distended and gorged with nothing but Galathea. G. intermedia was the commonest species, $G$. dispersa was also found fairly often, while Munida bamffica occurred twice. In March and April I949 as many as $30 \%$ of the stomachs examined had Galathea in them.

Porcellana sp. Porcellana forms a small yet consistent part of the food, being most common in the months just prior to spawning (Text-fig. 2F). $P$. longicornis is the common species found in the stomachs of Gadus minutus, though occasionally Porcellana platycheles has been observed in fish of the younger year groups in April and May 1949. In November 1948 Porcellana was found in about $16 \%$ of the stomachs examined.

Crangonidae. Crangon vulgaris and Philocheras bispinosus were the two species usually found in the food. Crangonidae were especially common just before and after spawning (Text-fig. 2 G). In April I948 and May I949 nearly I2 \% of the fish had ingested Crangonidae.

Amphipoda. Caprellidea (mainly Phtisica marina) were found in the stomachs more often in the months of April, May and June than in the other months, but Gammaridea formed a larger proportion of the amphipods consumed. The Gammaridea commonly found in the food were Apherusa ovalipes, A. henneguyi, Ampelisca spinipes and A. diadema. Mr G. M. Spooner informs me that Phtisica marina lives exclusively amongst hydroids and sponges and Ampelisca spp. are burrowers, usually lying buried under a surface layer of sand or gravel.

The occurrence of these amphipods in such large numbers in the stomachs of the poor-cod suggests a deliberate search on the part of the fish to ingest these forms and it further emphasizes the bottom-feeding nature of the fish.

Big specimens of $A$. spinipes measuring between 8 and $18 \mathrm{~mm}$. in length were common in the stomachs in August and September 1948 and in March and April I949. In August 1948 two specimens had in their stomachs 
I52 and I3I Apherusa spp. respectively. The proportion of amphipods in the total volume of food in the stomachs was comparatively small; yet a large number of fish had fed on them. In the latter part of the spawning season and in the months just following spawning the proportion of amphipods was larger than in other months (Text-fig. $2 \mathrm{H}$ ). Gammaridea were most common in July, August and September 1948. In May 1948 amphipods were found in about $40 \%$ of the stomachs examined.

Mysidacea and Euphausiacea. Schizopods form only a small proportion of the food of the fish, but were fairly consistent in their occurrence in the stomachs (Text-fig. $2 \mathrm{I}$ ). Leptomysis gracilis was the species most commonly ingested, and a few Anchialina were occasionally observed. In April and May 1948 a fairly large number of stomachs contained mysids and euphausiids ( $13 \%$ in April and $30 \%$ in May).

Others. Of the other organisms special mention should be made of Upogebia sp. and small Paguridae (mainly Eupagurus bernhardus). In May I949 Upogebia formed as much as $36 \%$ of the total volume of food, and about $10 \%$ of the fish had them in their stomachs. Paguridae also formed a large proportion in the food ( $26 \%$ of the total volume) in April 1949 and as many as $15 \%$ of the fish had ingested them.

Isopoda, Mollusca and Echinodermata formed only a negligible proportion of the food throughout the year. Occasionally they formed a large proportion in the food of a few individual stomachs. But such instances were very rare.

The various organisms that were found in the analysis of the food of the poor-cod of the adolescent years are given in the Appendix (p. 238).

Thus Gadus minutus in its adolescent and adult stages is primarily a crustacean feeder, feeding on the bottom-living forms and showing differential feeding activity depending on spawning and growth.

\section{Food of the O-Group of Gadus minutus}

Comparatively few specimens of the O-group were available for study of the food and they have been obtained during seven months only, viz.:

$\begin{array}{lclc} & \text { Specimens } & & \text { Specimens } \\ \text { Oct. I948 } & 5 & \text { March I949 } & 22 \\ \text { Nov. I948 } & \text { I59 } & \text { Apr. I949 } & 3 \\ \text { Jan. } 1949 & 21 & \text { May I949 } & 55 \\ \text { Feb. } \text { 1949 } & 364 & & \end{array}$

All these specimens were between 7 and $9 \mathrm{~cm}$. long (standard length). The numbers for October 1948 and April 1949 are negligible. The February 1949 and November 1948 collections alone are of any comparative value. The analyses of the food of $\mathrm{O}$-group in the different months are not therefore strictly comparable. This food analysis is therefore restricted to an enumeration of the food organisms and a comparison with the food of the older age groups. 
The poor-cod of the O-group also is primarily a crustacean feeder. Copepods, small Galathea intermedia, small Porcellana longicornis, and amphipods formed a large proportion of the food in all the seven months. Lebour (I9I9) also noted that the food of the poor-cod of a length from 40 to $160 \mathrm{~mm}$. 'is chiefly crustacea-copepods, especially Calanus and Temora, Podon, decapods and their larvae...' But the earlier post-larval stages are evidently still plankton feeders.

The average volume of food per stomach was 0. I2 c.c., compared with 0. 5 c.c. in the older fish. Empty stomachs were found only in November 1948 and February 1949, and their percentages were only $3 \%$ in November and $5 \%$ in February.

The majority of the stomachs contained fine sandy gravel mixed with empty shells of very small Natica sp. and Nucula sp.

The volumetric analysis of the food and the percentage composition of the stomachs containing the respective food organisms have been tabulated in Tables IV and V.

The various organisms that were found in the food of the O-group are given in the Appendix (p. 239).

Copepods were taken in all the 7 months. About $90 \%$ of the stomachs examined had copepods in them. Calanus finmarchicus and Acartia clausi were the commonest. The others were Temora sp., Pseudocalanus elongatus, and Centropages typicus. When the stomachs had a large copepod content they usually presented a reddish colour. Copepods were especially noticeable in November I948, February, March and May 1949.

Amphipods formed a great proportion of the food in November I948, February and May 1949. Caprellidea were very rare. They were found only in $\mathrm{I} \cdot 9 \%$ of the stomachs examined in the 7 months. Gammaridea formed almost the whole of the amphipodan element in the food. The species found were Apherusa sp. and juvenile forms of Ampelisca diadema and A. spinipes.

Galathea intermedia formed the greatest proportion of the food in January, February and March I949. In January and March 1949 as many as $60 \%$ of the stomachs examined had $G$. intermedia in them. All the $G$. intermedia were small and juvenile forms. The other decapod crustacea found in the food were Pandalina brevirostris, Philocheras bispinosus, Crangon vulgaris, small Porcellana longicornis, small Portunus spp., Eupagurus bernhardus and small Processa canaliculata.

Mysids and euphausiids were found mainly in January 1949, when as many as $55 \%$ of the stomachs contained them. Leptomysis gracilis and Nyctiphanes couch $i$ were the species taken.

In January 1949 many stomachs contained polychaetes mostly unrecognizable. The only identified species was Goniada sp.

Among Isopoda, Conilera cylindracea was taken from a few stomachs in November 1948 and February, March and May 1949. 


\section{Table IV. Volumetric Analysis of the Stomach Contents PER IOO STOMACHS (VOLUME IN C.C.)}

\begin{tabular}{|c|c|c|c|c|c|c|c|}
\hline \multicolumn{8}{|c|}{ O-group } \\
\hline Food organism & Oct. & Nov. & Jan. & Feb. & Mar. & Apr. & May \\
\hline Polychaeta & .. & 0.2 & I. 5 & $2 \cdot 4$ & 0.5 & $3 \cdot 3$ & \\
\hline Mollusca & .. & $0 . \mathrm{I}$ & $0 . \mathrm{I}$ & $0 \cdot 1$ & $0 . \mathrm{I}$ & .. & 0.2 \\
\hline Isopoda & .. & 0.4 & & $0 \cdot 2$ & 0.4 & . & 0.4 \\
\hline Amphipoda & $2 \cdot 0$ & $2 \cdot 4$ & 0.8 & $\mathrm{I} \cdot 4$ & 0.8 & .. & $\mathrm{I} \cdot 8$ \\
\hline Processa & 4.0 & 0.4 & 0.8 & 0.4 & I.O & . & 0.4 \\
\hline Crangonidae & 3.0 & 0.6 & $\mathrm{I} \cdot \mathrm{O}$ & $0 \cdot 1$ & .. & & 0.2 \\
\hline Galathea & 6.0 & $2 \cdot 8$ & $5 \cdot 0$ & $4 \cdot I$ & 3.0 & $6 \cdot 6$ & I. 0 \\
\hline Portunus & .. & & 0.4 & 0.6 & & .. & 0.6 \\
\hline Porcellana & .. & 0.2 & $2 \cdot \mathrm{I}$ & $\mathrm{I} \cdot 9$ & 0.7 & .. & 0.8 \\
\hline Baguridae & .. & & .. & 0.2 & & .. & \\
\hline Copepoda & 0.2 & 0.2 & $0 . I$ & 0.4 & 0.2 & $O \cdot I$ & 0.2 \\
\hline Schizopoda (sens. lat.) & & 0.4 & 0.4 & 0.3 & 0.2 & & 0.2 \\
\hline $\begin{array}{l}\text { Sandy gravel } \\
\text { and stone }\end{array}$ & 0.8 & 0.2 & 0.5 & 0.1 & 0.4 & 0.6 & 0.2 \\
\hline Others & 0.4 & 0.8 & 0.9 & I.O & I.7 & .. & 0.7 \\
\hline $\begin{array}{l}\text { Total volume } \\
\text { in c.c. }\end{array}$ & I $6 \cdot 4$ & $8 \cdot 7$ & 13.6 & $13 \cdot 2$ & $9 \cdot 0$ & $10 \cdot 6$ & $7 \cdot 3$ \\
\hline $\begin{array}{l}\text { No. of stomachs } \\
\text { examined }\end{array}$ & 5 & 150 & $2 \mathrm{I}$ & 350 & 22 & 3 & 55 \\
\hline
\end{tabular}

Table V. Percentage of Prevalence of the Food Organisms IN THE STOMACHS EXAMINED

\begin{tabular}{|c|c|c|c|c|c|c|c|}
\hline & \multirow[b]{2}{*}{ Oct. } & \multicolumn{2}{|c|}{ O-group } & \multirow[b]{2}{*}{ Feb. } & \multirow[b]{2}{*}{ Mar. } & \multirow{3}{*}{$\begin{array}{c}\text { Apr. } \\
66\end{array}$} & \multirow{3}{*}{ May } \\
\hline Food organism & & Nov. & Jan. & & & & \\
\hline Polychaeta & .. & 2 & 55 & 12 & 23 & & \\
\hline Mollusca & .. & 10 & 20 & 3 & 23 & .. & 46 \\
\hline Isopoda & .. & 3 & .. & I & 20 & .. & \\
\hline Amphipoda & 100 & I6 & 75 & I8 & 70 & . & 32 \\
\hline Processa & 20 & 3 & Io & I & I5 & $\cdots$ & 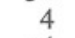 \\
\hline Crangonidae & 20 & 3 & Io & 2 & & & \\
\hline Galathea & 60 & 28 & 60 & 40 & 65 & 100 & Io \\
\hline Portunus & .. & . & 5 & 4 & $\ldots$ & .. & 4 \\
\hline Porcellana & .. & 2 & 20 & 10 & 25 & .. & 6 \\
\hline Paguridae & . & $\cdots$ & .. & I & & .. & \\
\hline Copepoda & 100 & 72 & 100 & 92 & 95 & 100 & 76 \\
\hline Schizopoda (sens. lat.) & $\ldots$ & 12 & 55 & 6 & 20 & & 0 \\
\hline Sandy gravel & 100 & 66 & 80 & 29 & 85 & 66 & 62 \\
\hline
\end{tabular}

Lebour (1917, I919) examined the food of I44 post-larvae measuring 6-I4 mm., and fifty-three specimens of the O-group of Gadus minutus in I9I7 and I919. The records of her analysis of the food of these fish were as follows:

I40 specimens of G. minutus post-larvae measuring 6-I4 mm., from the Young Fish Trawl of 1914, were examined (Lebour, I9I7, p. 455). Of these 4 stomachs were empty, I contained ova, I contained Dinophysis, I34 contained Pseudocalanus elongatus, with Acartia, Euterpina, Metrida and Podon each occurring once.

In I919, 4 specimens of 6-13 mm. long post-larvae and 53 specimens of the Oand I-groups of Gadus minutus were examined (Lebour, I9I9, pp. 283-5).

Analysis of the post-larvae: one empty, two contained copepod remains, one contained I Pseudocalanus and one young Temora. 
Analysis of the O-group and I-group:

\begin{tabular}{|c|c|c|}
\hline $\begin{array}{l}\text { No. of } \\
\text { specimens }\end{array}$ & $\begin{array}{l}\text { Length } \\
\text { in } \mathrm{mm} \text {. }\end{array}$ & Food \\
\hline I & 40 & $\begin{array}{l}\text { Crystallogobius, many Podon, Calanus, Temora, remains of } \\
\text { decapod larvae }\end{array}$ \\
\hline 3 & $60-70$ & $\begin{array}{l}\text { Crustacean remains, many Acartia, Candacia, Temora, de- } \\
\text { capod larvae, young amphipods and isopods }\end{array}$ \\
\hline 5 & $70-80$ & $\begin{array}{l}\text { Temora, Candacia, decapod larvae remains, Calanus and one } \\
\text { empty }\end{array}$ \\
\hline 5 & $80-90$ & $\begin{array}{l}\text { Copepod remains, Calanus, Pseudocalanus, decapod larvae, } \\
\text { Candacia and Eupagurus larvae. }\end{array}$ \\
\hline 8 & $90-105$ & $\begin{array}{l}\text { Copepod remains, annelid remains, Pandalus montagui and } \\
\text { decapod remains }\end{array}$ \\
\hline 19 & $73-105$ & Indistinguishable \\
\hline 5 & $69-110$ & Crangon remains \\
\hline I & 135 & Labidocera wollastoni, many Calanus \\
\hline I & I43 & 4 Crystallogobius, mysid, and many Calanus \\
\hline 5 & $83-160$ & Decapod remains (Leander?) \\
\hline
\end{tabular}

Only three post-larvae of Gadus minutus occurred in the present material and all of them contained Pseudocalanus in their stomachs. Lebour's analysis of the food of I44 post-larvae quoted above showed that the great majority contained copepods, amongst which Pseudocalamus elongatus was always present. Other species each occurred once only. It is quite evident, as Lebour emphasizes, that Pseudocalanus is the favourite food of Gadus minutus in its post-larval stages.

Lebour's analysis revealed that the food of $G$. minutus contained fish and crustacea at the respective stages as follows:

6-I4 mm. (total length)

Copepods, ova,

Dinophysis

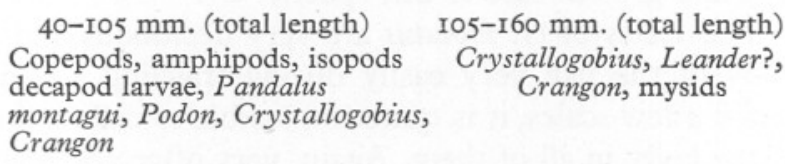

Lebour further stated that Gadus minutus 'in their young stages eat Pseudocalanus more than anything else, Acartia and other small copepods also being taken, probably when Pseudocalanus is not so abundant. Calanus is taken by the larger but rarely by the smaller fish.'

The present analysis also reveals this fact well. The O-group $(7-9 \mathrm{~cm}$. standard length) contained copepods, amphipods and small decapods like Galathea intermedia, Porcellana longicornis and small Portunus spp. besides occasional inclusions of polychaetes, mysids, and isopods. There was a complete absence of fish in the food analysed. Even Lebour found fish in only two specimens of the sample, one of which was $14.3 \mathrm{~cm}$. in total length and therefore belonged to the I-group. Thus copepods, amphipods and Galathea formed the bulk of the food of the poor-cod of the O-group.

In the food of the I-V groups the bigger decapods like Processa canaliculata, Portunus sp. and Galathea spp., and fish like Callionymus sp., Trigla sp. and Crystallogobius sp., and polychaetes formed the major portion throughout the year. Copepods were observed only in four stomachs in the food analysis of 
these age groups. It is quite evident that copepods do not play any important part in the food and feeding of the fish at this adolescent and adult period of its life.

The food of $G$. minutus can thus be divided into three categories depending on the three phases of its life cycle, as follows:

\begin{tabular}{|c|c|c|}
\hline Stage & $\begin{array}{l}\text { Length in mm. } \\
\text { (Standard length) }\end{array}$ & Food \\
\hline Post-larval & $6-I_{4}$ & Copepods, mostly Pseudocalanus elongatus \\
\hline O-group & $40-80$ & $\begin{array}{l}\text { Copepods, mostly Calanus finmarchicus, Acartia and Temora; } \\
\text { small decapods like Galathea intermedia, Porcellana } \\
\text { longicornis, etc.; amphipods, mostly Gammaridea; iso- } \\
\text { pods and polychaetes }\end{array}$ \\
\hline $\left.\begin{array}{c}\text { Adolescent } \\
\text { and adult } \\
\text { stages }\end{array}\right\}$ & $80-230$ & $\begin{array}{l}\text { Decapods, mostly the larger like Processa canaliculata, } \\
\text { Galathea sp., Portunus sp., Porcellana sp., Upogebia; } \\
\text { fish like Crystallogobius and Callionymus sp.; poly- } \\
\text { chaetes, mostly Amphitrite and Goniada, amphipods like } \\
\text { large Ampelisca spp., Apherusa spp. and Phtisica marina }\end{array}$ \\
\hline
\end{tabular}

\section{Age and Growth Determination in GadUS MINUTUS}

In his studies of the rate of growth of Plymouth fishes Cunningham (I89I) made some observations on the growth rate of Gadus minutus from length measurements. He examined 246 specimens collected between I 889 and I89I. After that J. S. Thomson (1904) used the scales of G. minutus in his investigation on the validity of scales as an index of age in Gadidae. Apart from these two early investigations there is no other reported work on the age determination and growth rate of this species.

The scales of $G$. minutus are very deciduous and get scraped off from the body of the fish very easily during trawling. Even with specimens which retain a few scales, it is quite impossible to collect them from the same region of the body in all of them. Again, very often the retained scales turned out to be the minute scales which Stuart Thomson (1904) has described in his paper. Harold Thompson (1922) has shown in his treatise on haddock scales how essential it is to collect the largest scales, and that too from one and the same region in all the specimens, if any assessment of age and if any valid and reasonable comparison between the several specimens can be made. In the present work the scales were used for deciphering the age only in the relatively few specimens where this was possible. They could not be used for any assessment of back-calculation and growth rate. For age determination in G. minutus, the otoliths at first were used. The otoliths are very massive and thick structures, and to reveal the 'year rings' they had to be broken transversely and sometimes even sectioned before the rings could be distinguished. Though the zones were quite clear in most of them there was no uniformity in the width of the zones, and it was not practically possible to make sections at the same sagittal plane in all the otoliths. For these reasons it was impossible to utilize the otolith for critical comparisons and for purposes of backcalculation. Therefore some other structure had to be selected for a satisfactory 
estimation of the age and growth rate, possessing all these necessary traits of an 'age index'. The supra-occipital crest was selected with this in view.

Bones have rarely been used for age determination of marine fishes and even when they have, there have been differences of opinion on the validity of the zones, as is clear from a survey of the literature (Menon, I950). The main objection against utilizing bones for age assessment has been that the zones are ill-defined. This difficulty can usually be overcome by finding out the optimum temperature for cooking the specimens when collecting the bones. Overcooking always blurs the zones. When the bones are prepared without overcooking it is found that age assessments can be based on them with at least as much confidence as on scales or otoliths.

\section{Growth rate from scales}

Scales were collected from all specimens in which they were available. Only those scales which were firmly lodged in the scale pockets were collected as, being extremely deciduous, there was a possibility of scales from different specimens getting intermingled on the fishes when they came up in the trawl. These scales were removed with a scalpel and stored in labelled envelopes. Altogether scales were collected from 294 specimens, from whichever region of the fish they were remaining in their pockets. The scale of $G$. minutus has a thin shining dermal tissue covering it, often with big stellate chromatophores. These obscure the sclerites and it is necessary to clean the scale before it can be read under the microscope clearly. The best method of cleaning the scale is to put it in a solution of $10 \%$ caustic potash for $5 \mathrm{~min}$. and then to scrape it in water in a watch-glass with a forceps and a needle. All the dermal tissues and chromatophores can easily be removed by this method. The scale is then mounted on a slide. The treatment with caustic potash imparts a deep black tinge to the sclerites, which thus become clearly defined and visible in the general field of the scale. Alizarine stain also enhanced the clarity of the sclerites and 'rings'. After removal of its chromatophores and dermal tissues the scale is placed in alizarine staining solution for $5 \mathrm{~min} .{ }^{1}$ The excess stain is washed off by leaching the scale in $2 \%$ caustic potash solution, and then the scale is mounted in glycerine. The 'annual rings' become very clearly defined. This method was better, easier and quicker than that suggested by Graham (I929a).

The scale of G. minutus, like the scales of most Gadidae, is oval in shape, with several sclerites arranged around a central nucleus (Pl. II, fig. I). The sclerites are arranged in alternating bands of widely separated ones, which constitute the so-called 'summer zone' and of closely approximated ones, which constitute the 'winter zone or ring'.

\footnotetext{
1 Alizarine staining solution: $5 \%$ caustic potash, rooo c.c.; alizarine dye solution, I c.c. Alizarine dye solution: glacial acetic acid, 0.5 c.c.; glycerine, 3 c.c.; chloral hydrate ro c.c. and alizarine sulphonate $0.1 \mathrm{~g}$.
} 
The difficulty of getting scales from the same region of the fish in all specimens has been explained in the preceding paragraphs. They are therefore not comparable in size. The measurements of these scales made with a micrometer scale verified that there is no regularity in the measurements of scales from the different specimens. The zones are very clearly defined in stained scales and fairly distinguishable in unstained ones. Unfortunately, no data of blank scales were kept and so a probable or approximate percentage of them

\section{Table VI. Analysis of the Scales of Gadus minutus ACCORDING TO THE LENGTH- AND AgE-GROUPS}

\begin{tabular}{|c|c|c|c|c|c|c|c|c|c|c|c|c|}
\hline \multirow{3}{*}{$\begin{array}{l}\text { Length } \\
\text { in } \mathrm{cm} .\end{array}$} & \multicolumn{11}{|c|}{ Year groups } & \multirow[b]{3}{*}{ Total } \\
\hline & \multicolumn{5}{|c|}{ Male } & \multicolumn{6}{|c|}{ Female } & \\
\hline & I- & $I+$ & $2+$ & $3+$ & $4+$ & I- & $\mathrm{I}+$ & $2+$ & $3+$ & $4+$ & $5+$ & \\
\hline $7 \cdot 5$ & 3 & . & .. & .. & .. & 3 & .. & .. & .. & .. & .. & 6 \\
\hline $8 \cdot 0$ & 3 & 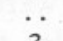 & .. & . & .. & 4 & .. & .. & . & .. & . & 7 \\
\hline $8 \cdot 5$ & 5 & 2 & .. & .. & .. & 4 & 3 & .. & .. & . & .. & I4 \\
\hline $9 \cdot 0$ & I & 5 & .. & .. & .. & I & 4 & .. & .. & .. & . & II \\
\hline $9 \cdot 5$ & .. & 4 & .. & .. & .. & . & 5 & .. & .. & $\ldots$ & $\ldots$ & 9 \\
\hline 10.0 & .. & 5 & .. & .. & .. & I & 2 & .. & .. & .. & $\ldots$ & 8 \\
\hline 10.5 & .. & 3 & .. & .. & .. & $\cdots$ & 2 & .. & .. & .. & .. & 5 \\
\hline II 0 & $\ldots$ & I & .. & .. & .. & $\ldots$ & 3 & .. & $\ldots$ & $\ldots$ & $\ldots$ & 4 \\
\hline II 5 & .. & .. & .. & $\ldots$ & .. & .. & .. & .. & .. & .. & .. & $0_{0}^{+}$ \\
\hline 12.0 & $\ldots$ & I & .. & .. & $\ldots$ & .. & I & .. & .. & $\ldots$ & .. & 2 \\
\hline 12.5 & $\ldots$ & 5 & 3 & .. & .. & .. & .. & .. & .. & $\ldots$ & $\ldots$ & 8 \\
\hline 13.0 & .. & 2 & 4 & .. & .. & .. & 2 & .. & .. & .. & $\ldots$ & 8 \\
\hline 13.5 & .. & 3 & 8 & .. & .. & .. & 4 & 4 & .. & .. & $\ldots$ & 19 \\
\hline 14.0 & $\ldots$ & 3 & 15 & I & .. & . & 3 & 2 & .. & .. & $\ldots$ & 24 \\
\hline 14.5 & .. & I & 9 & I & .. & . & 4 & 8 & I & .. & $\ldots$ & 24 \\
\hline 15.0 & .. & .. & 3 & 3 & I & $\ldots$ & 4 & I8 & 5 & .. & $\ldots$ & 34 \\
\hline 15.5 & .. & .. & .. & 3 & .. & .. & 2 & 9 & I & .. & $\ldots$ & 15 \\
\hline 16.0 & $\ldots$ & $\ldots$ & $\ldots$ & I & I & $\ldots$ & $\ldots$ & I7 & 4 & .. & .. & 23 \\
\hline 16.5 & $\ldots$ & $\ldots$ & $\ldots$ & 2 & I & $\ldots$ & $\ldots$ & $\mathrm{I} 4$ & 3 & .. & $\ldots$ & 20 \\
\hline 17.0 & $\ldots$ & $\ldots$ & $\ldots$ & $\ldots$ & I. & $\ldots$ & $\ldots$ & 5 & 4 & .. & $\ldots$ & Io \\
\hline 17.5 & $\ldots$ & $\therefore$ & $\ldots$ & $\ldots$ & $\ldots$ & $\ldots$ & $\ldots$ & 2 & 7 & I & .. & IO \\
\hline 18.0 & $\ldots$ & $\ldots$ & $\ldots$ & $\ldots$ & $\ldots$ & $\ldots$ & $\ldots$ & 2 & 6 & .. & .. & 8 \\
\hline $18 \cdot 5$ & .. & $\ldots$ & $\ldots$ & $\ldots$ & $\ldots$ & . & $\ldots$ & $\ldots$ & 5 & .. & $\ldots$ & 5 \\
\hline 19.0 & .. & $\ldots$ & $\ldots$ & $\ldots$ & . & .. & $\ldots$ & $\ldots$ & 7 & 2 & $\ldots$ & 9 \\
\hline I9.5 & .. & .. & $\ldots$ & $\ldots$ & $\ldots$ & $\ldots$ & $\ldots$ & $\ldots$ & 4 & 3 & $\ldots$ & 7 \\
\hline 20.0 & $\ldots$ & .. & $\ldots$ & $\ldots$ & .. & . & $\ldots$ & $\ldots$ & I & 2 & $\mathrm{I}$ & 4 \\
\hline \multirow[t]{2}{*}{ Totals } & 12 & 35 & 42 & II & 4 & I3 & 39 & $8 \mathrm{I}$ & 48 & 8 & I & 294 \\
\hline & \multicolumn{5}{|c|}{ IO4 } & & \\
\hline
\end{tabular}

in the specimens examined cannot be given, but their proportion was high. There were several instances of false rings in the scales and with all these the age had to be checked by reference to the otoliths and supraoccipital.

The data of measurements of the scales are not given since they are not comparable. In Table VI are shown the various $5 \mathrm{~mm}$. groups, the two sexes separately, divided up according to the number of 'closely arranged sclerite zones' or 'annual rings' in the scales that have been examined.

From Table VI it is quite evident that there is a different rate of growth in the two sexes. The majority of male G. minutus are more than I year old 
when they reach a length of $9 \mathrm{~cm}$., past 2 years at a length of $\mathrm{I}_{3} \mathrm{~cm}$., past 3 years when they reach a length of $15.5 \mathrm{~cm}$. and past 4 years at a length of $16.5 \mathrm{~cm}$. In the same way the majority of females are past I year at $9 \mathrm{~cm}$., past 2 years at $14.5 \mathrm{~cm}$., past 3 years at $17.5 \mathrm{~cm}$., and past 4 years at $20 \mathrm{~cm}$. Thus at the end of the Ist, 2nd, 3 rd and 4 th years the fish reaches approximate lengths of $8.5-9,12 \cdot 5-13, \mathrm{I} 5-15.5$, and $16.5-17 \mathrm{~cm}$. in the male and $8.5-9$, $\mathrm{I} 4-\mathrm{I} 4.5, \mathrm{I} 7-\mathrm{I} 7.5$ and $19.5-20 \mathrm{~cm}$. in the female respectively. If we take the mean of each year's length range as the nearest approximation to the actual length, the average fish reaches the lengths shown in Table VII at the end of each year in the male and female respectively.

These average or 'mean' lengths are equivalent to the 'calculated lengths' given on p. 219.

Stuart Thomson examined the scales of fifty-six specimens ranging from 3.3 to $19.5 \mathrm{~cm}$. (total length). He counted the number of sclerites in each zone and found the width of each annual zone by measuring along the long axis the distance from the centre of the scale of 'the nucleus' to the outer edge of

Table VII. Average Lengths (CM.) at Different Ages

$\begin{array}{ccc}\text { At the end of } & \text { Male } & \text { Female } \\ \text { Ist year } & 8 \cdot 75 & 8.75 \\ \text { 2nd year } & 12.75 & 14.25 \\ \text { 3rd year } & 15.25 & 17 \cdot 25 \\ \text { 4th year } & 16.75 & 19 \cdot 75\end{array}$

each 'ring'. The results have been given as a correlation curve in Text-fig. 3 . In the graph the distance from the centre of the scale to its outer edge is plotted as curve $E$. The line $R^{\mathrm{I}}$ and the points $R^{\mathrm{II}}$ are the distances from the centre of the scale to the first and second rings, i.e. the annual growth of the scale in the Ist and 2nd years. Thomson did not separate the sexes, and his data cannot be analysed from that aspect. Also he measured no scales of fish between lengths of 6.8 and IO, I4.3 and 18.8 and above $19.5 \mathrm{~cm}$. Yet his data reveal certain interesting details. It can be seen from the graph that $G$. minutus is past I year when it reaches a length of $\mathrm{IO} \mathrm{cm}$. (total length) and just past 2 years when it is $15.87 \mathrm{~cm}$. (total length). Thomson noted that a fish of $19.36 \mathrm{~cm}$. (total length) is just past 3 years. Converting these lengths into standard lengths for comparing them with the writer's observations, they become 9, I4 and $17 \cdot 2 \mathrm{~cm}$. approximately. Thomson examined scales from the median region of the flanks slightly posterior to the pectoral fin and either slightly above or below the lateral line. His data for the fish above $19.36 \mathrm{~cm}$. (total length) give very conflicting results, as all these fish are said to be above 2 and below 3 years. That fish of 23.5 and of $19.36 \mathrm{~cm}$. (total length) are not of the same year class is clear-because, while the growth in the Ist, 2nd and $3^{\text {rd }}$ year is IO, 5.87 and $3.49 \mathrm{~cm}$. (total lengths) respectively, decreasing systematically every year, if the group $19 \cdot 36-23 \cdot 5 \mathrm{~cm}$. belongs to the same year group, viz. the 4 th year group, it means that the growth in the 4 th year is greater 


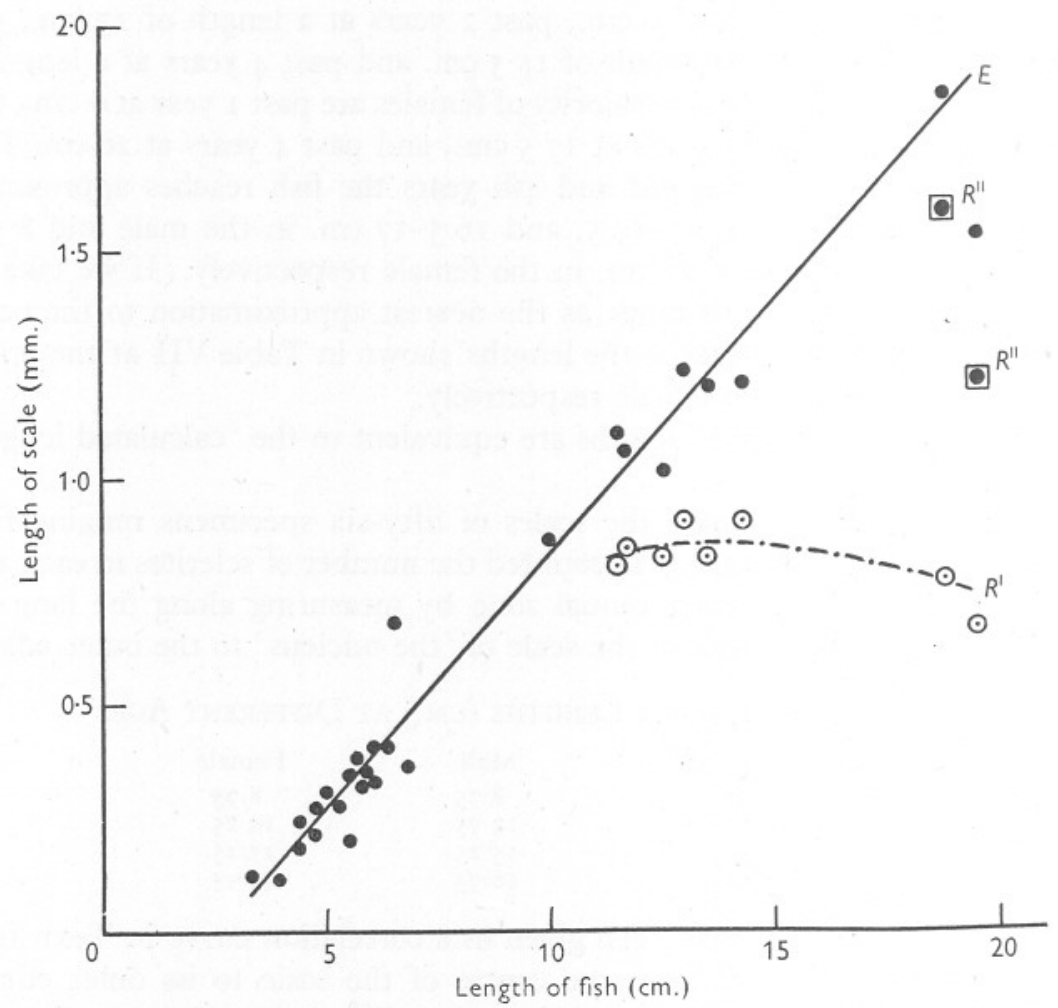

Text-fig. 3. The length in $\mathrm{mm}$. of the scale from its 'centre' to its 'edge' at the different lengths of fish (data from J. S. Thomson, I904). $\bullet$, measurements of the scale from the centre to the edge $(E)$; $\odot$ measurements of the scale from the centre to the first ring $\left(R^{\mathrm{I}}\right)$; $\emptyset$, measurements of the scale from the centre to the second ring $\left(R^{\mathrm{II}}\right)$.

\section{Table VIII. Thomson's Measurements of Gadus minutus Scales}

\begin{tabular}{|c|c|c|c|c|c|}
\hline \multirow{2}{*}{$\begin{array}{l}\text { Total length } \\
\text { in } \mathrm{cm} .\end{array}$} & \multirow{2}{*}{$\begin{array}{l}\text { Average length of } \\
\text { scale in mm. from } \\
\text { centre to growing edge }\end{array}$} & \multicolumn{3}{|c|}{ Average no. of sclerites } & \multirow[b]{2}{*}{ Approximate age } \\
\hline & & I & 2 & 3 & \\
\hline $3 \cdot 3$ & 0.12 & 0 & . & . & 3 months \\
\hline $3 \cdot 9$ & $0.2 \mathrm{I}$ & 4 & . & . & 3 months \\
\hline $5 \cdot 0-5 \cdot 9$ & 0.34 & 7 & . & . & 3 months \\
\hline $6 \cdot 0-6 \cdot 8$ & 0.47 & 8 & . & $\cdots$ & 3 months \\
\hline 10.0 & 0.86 & 23 & .. & . & I yr. I month \\
\hline $\mathrm{II} \cdot 5-\mathrm{II} \cdot 7$ & 1.07 & 30 & 9 & $\cdots$ & I yr. 3-4 months \\
\hline$I 2.5-I 4.3$ & $\mathrm{I} \cdot \mathrm{I} 8$ & 29 & II & . & I yr. $3-4$ months \\
\hline I5.87 & Not taken & $\therefore$ & . & . & 2 yrs. I month \\
\hline I7.I4-I8.09 & Not taken & . & . & $\cdots$ & 2 yr. 7 months approx. \\
\hline I 8.80 & $I \cdot 84$ & 26 & 25 & II & 2 yr. $3-4$ months \\
\hline $19 \cdot 36$ & Not taken & . & $\therefore$ & $\cdots$ & 3 yr. I month \\
\hline 19.50 & $I \cdot 53$ & I9 & $2 I$ & I6 & About 3 yr. \\
\hline 19.68 & Not taken & . & . & $\ldots$ & Under 3 yr. \\
\hline $20 \cdot 32$ & Not taken & . & . & . & 2 yr. I month \\
\hline $22 \cdot 22$ & Not taken & .. & .. & $\cdots$ & I yr. II months \\
\hline 23.75 & Not taken & . & . & $\ldots$ & 2 yr. II months \\
\hline
\end{tabular}


than the 3 rd year. This evidently suggests that the $19 \cdot 36-23.5 \mathrm{~cm}$. length group must have really consisted of more than one year group. This conflicting result in the data of Thomson must have arisen from the difficulty of reading the scales of older age groups. Thomson's data are summarized in Table VIII.

Thus from Thomson's data one finds that the length-groups 3.3-10 and IO-I5.87 cm. belong to O- and I-groups respectively. Above $15.87 \mathrm{~cm}$. the results are not very definite. As far as the O- and I-groups are concerned, Thomson's values agree quite well with the present results. In the writer's experience, above the I-group the sclerites become very close and crowded, and in the few scales that were examined there was great difficulty in identifying the rings. In most of them the rings could not be satisfactorily discerned without the previous knowledge of the probable age of the fish from the supra-occipital or the otolith. It must have been this evident overcrowding and narrowing of the sclerites that forced Thomson to overlook the rings after the first 2 years.

\section{Growth rate from the otolith}

The otoliths were collected by making a vertical cut in the skull behind the orbit and bending the front portion of the skull as suggested by Hickling (I933). When the heads alone were boiled they were collected after boiling and removing the supra-occipital. No change, or difficulty in reading the otoliths,

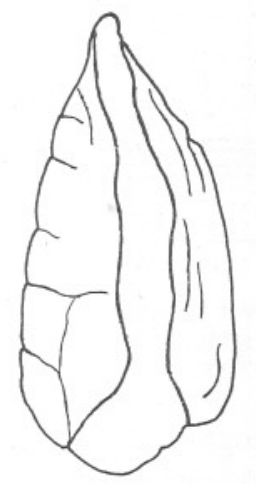

A

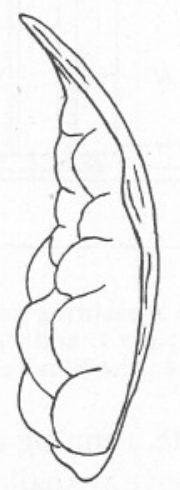

B

Text-fig. 4. Diagram of the otolith of Gadus minutus showing (A) its dorsal aspect and (B) its sagittal aspect.

of boiled specimens was found. The otolith of G. minutus is roughly dropshaped with a slight concavity on its ventral side (Text-fig. 4). The posterior end of the otolith is bulbous and the anterior end tapers to a blunt point which bends downwards in the natural position.

On the dorsal surface there is a fairly broad but shallow acoustic canal. The ventral surface is rugose and has several thick and massive bulbous excrescences. These bulbous swellings are especially massive towards the middle and 
posterior end of the otolith. They contribute to the thickness and mass of otolith, and make it impossible to read the otolith without cutting it. For age determination the otolith is cut transversely at about its widest and thickest region. The cut surfaces are then moistened with water, or glycerine, or even better with saliva, when they show the opaque and translucent bands clearly. With several it was found necessary to make ground sections, as in rock-sectioning, to read the zones clearly and satisfactorily (Plate II, figs. 2, 3). The method of grinding employed was much as suggested by Johnston (1938), with the only difference that the grinding was performed by hand with the aid of carborundum and a ground-glass plate.

The length and greatest thickness of the otolith were measured with a scale made for the purpose (Text-fig. 5). This consists of two small rectangular blocks of wood attached at right angles to one another. Each block has

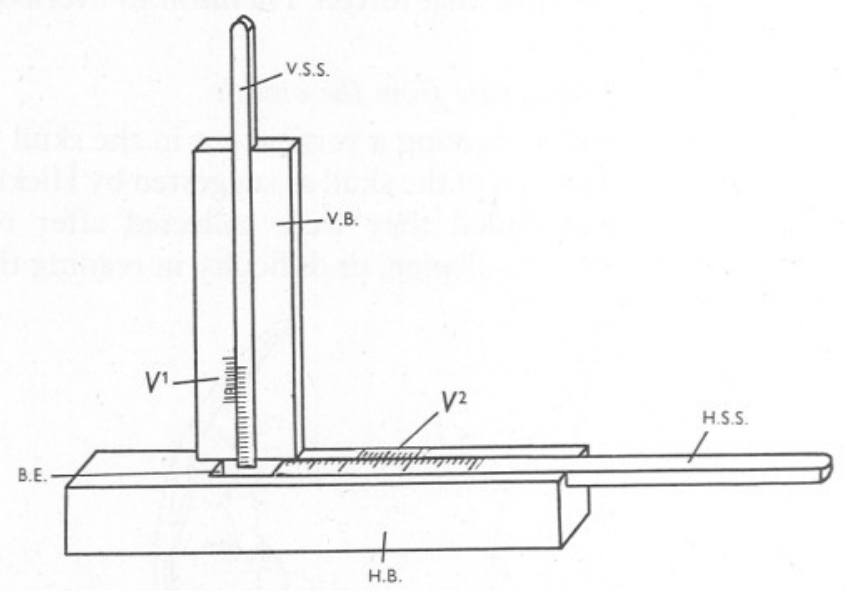

Text-fig. 5. The otolith measuring scale (not drawn to scale). H.B. and v.B., the horizontal and vertical blocks; H.S.S. and v.S.S., the horizontal and vertical sliding scales; $V^{1}$ and $V^{2}$, the verniers; B.E., the blind end of the groove.

a groove, $7 \mathrm{~mm}$. wide, running along its length up to the junction between the two blocks. The groove is shallow and wide enough to receive the widest and thickest otolith of $G$. minutus. Sliding wooden scales as wide and high as the grooves work in each. These scales may be called the 'vertical' and 'horizontal' scales. The blocks are so fixed to each other that the end of the vertical scale dips and fits into the horizontal groove at its blind end. The zero end of each scale is towards its outer end. Towards the zero end of each scale there is a vernier scale on the border of the groove. The otolith, when being measured, is placed at the blind end of the horizontal groove with its rugose side upwards. The horizontal scale is then moved towards the blind end until it holds the otolith firmly and straight. The length of the otolith can then be read on the horizontal scale and its vernier. To measure the thickness of the otolith, the 
horizontal scale is released and the otolith is so adjusted, lying in the same position, as to place its thickest portion just beneath the 'dipping end' of the vertical scale. The vertical scale is then moved down to hold the otolith rigidly and the thickness is read on the vertical scale and its vernier.

The whole procedure is easy and rapid. It avoids the difficulties one encounters with an ordinary metal screw-guage or vernier, where there is the possibility of the blunt end of the otolith breaking and of not taking the measurements at the longest axis. The readings with the scale just described are as accurate as those with a screw-guage or vernier since it is possible to measure in mm. up to two decimal places.

As many as 600 otoliths were measured with this scale and the data revealed certain interesting points.

There is virtually no correlation (i) between the length of the fish and the length of the otolith, or (ii) between the length of the fish and the thickness of the otolith. There is no correlation (iii) between the length and thickness of the otolith, or (iv) between the otolith measurements and the sex or age of the fish.

There is no particular rule for the calcium accumulations of the otolith. An otolith of a 2-year-old fish may be as long and thick as that of a 3- or even 4-year-old one. Again, the otoliths of fish of the same age may show very different dimensions, the range of variation being quite big. This makes it difficult to compare the otoliths of fish of the same age or the same length or the same sex.

This fact was again revealed by the few measurements made of the width of the zones of the otolith. These are not published, because several sources of error seemed unavoidable. For example, it is not possible to cut the sections in precisely the same sagittal plane in all the otoliths, so that the measurements are not strictly comparable with one another. Instead the fish have been tabulated in $5 \mathrm{~mm}$. length groups, against their age as assessed by the number of annual zones in the otoliths only, and treated in the same way as with the data relating to the scale readings (Table IX). From this it appears that the majority of male fish are past their first year when they reach a length of $10 \mathrm{~cm}$., past 2 years at $13.5 \mathrm{~cm}$., past 3 years at $16 \mathrm{~cm}$., and past 4 years at $17.5 \mathrm{~cm}$. The corresponding lengths for females were $10,15,18$ and $19.5 \mathrm{~cm}$. If the means are then calculated as with the data for scale readings, we get the 'calculated lengths' of the fish shown in Table X.

The zones in the otolith become very crowded at the periphery of the sections in the older age groups and it becomes a difficult problem to differentiate the various zones. False zones and 'doubled zones' are very prevalent. The massive nature of the otoliths and the lack of correlation in their measurements leave them useful only for direct age reading (even this is trustworthy only for the first two year-groups). Their zonations cannot be used for back-calculation. 
Table IX. Analysis of the Otoliths of Gadus minutus According To THE LENGTH AND AGE OF THE Fish

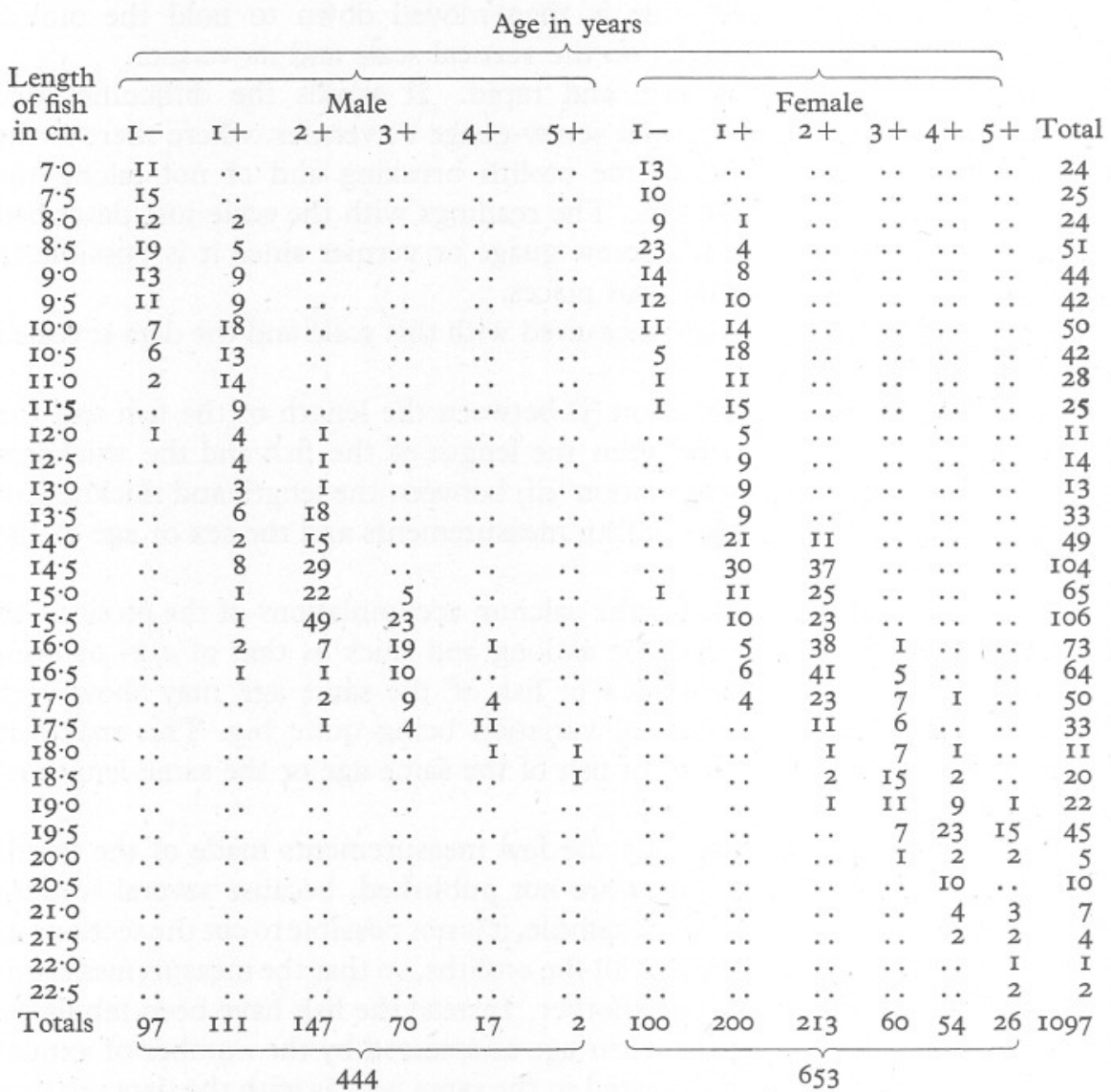

Table X. Calculated Lengths from Otoliths

Calculated lengths in $\mathrm{cm}$.

At the end of
Ist year
2nd year
3rd year
4th year

$\begin{array}{rc}\text { Male } & \text { Female } \\ 9.75 & 9.75 \\ 13.25 & 14.75 \\ 15.75 & 17.75 \\ 17.25 & 19.25\end{array}$

Growth rate from the Supra-Occipital Crest

The supra-occipital crest or spine is a thin flat piece of bone projecting from the posterior part of the skull like a triangular crest in the median line. The crest is made up of two parts, a frontal portion and a supra-occipital portion. The anterior frontal portion forms only a small part in the total crest. It starts 
roughly in the anterior one-third of the frontal in the median line and rises from the skull at an angle of $45^{\circ}$ (approx.). Immediately after passing the anterior one-third of the frontal, the crest bends back at an angle of $30^{\circ}$ (approx.) to the plane of rise of the bone, and runs back to join the supraoccipital portion of the crest. The posterior edge of the frontal portion of the crest is split mesially, and the anterior edge of the supra-occipital portion of the crest is lodged in this split like the blade of a pen-knife when closed. It is a sort of interlocking joint which is more or less in the shape of an isosceles triangle. At the apex of this triangle, at the junction of the two portions of the crest, there is a slight depression of the border.

\section{Method of Preparation}

The method of collection of the supra-occipital was as follows. The fish was measured, its stomach removed and the sex determined. Then a small tape with the serial number of the fish written on it with chinese black ink or marking ink was pinned through its lower jaw and through the orbit on the opposite side. This enabled the pin to pass in between the roof of the skull and the palatine bridge and thus ensured the safety of the label in subsequent boiling. Brass safety pins were used as there was no chance of their rusting and corroding, and the same pins could be used over again for several samples. After the specimens had been labelled the heads were cut out behind the pectoral axil. These heads were then placed in a water-bath and cooked up to $80^{\circ} \mathrm{C}$. The temperature at which the heads are cooked is a very important factor in the utilization of bones for age determination. If the heads are overcooked the bones assume an opaque consistency and their structure is blurred. It is always best to find out the optimum temperature for the cooking or, if that is not possible, to undercook rather than overcook. This is especially important when dealing with the heads of specimens of $\mathrm{O}$ - and I-year groups. After cooking, the flesh and other tissues from the skull were removed by washing the skull with a powerful jet of water. In that wet state all the bones are loose and disarticulated. The supra-occipital crest can be easily pulled out of the skull and it comes off with the supra-occipital bone attached to it like a narrow sloping base on either side of the crest. With sharp scissors this base of the supra-occipital bone was cut out from both sides of the base of the crest. The supra-occipital appears then as a clean, thin, flat piece of bone with no protuberances. The bone was then placed in a labelled envelope and exposed to the air on a wooden tray. It became dry in $24 \mathrm{hr}$. This is the best way of drying the bones. If the bones are dried in the heat of an electric bulb or over a warm plate, the zones become extraordinarily clear, but such artificial heat is apt to warp the bones in such a way as to interfere with the later measurements. When these bones are stored in the envelopes in a warm place the zones become quite clear and defined. The clarity of the zones increased with storage and drying. Rarely bones from 
the older females contained a little fat. If this was not removed the bones took on a murky brown colour which blurred the zones to some extent during storage. The fat was removed by treatment with a mixture of equal amounts of benzene and ether, which yielded fine preparations within $24 \mathrm{hr}$. No difference was noticed in the nature and clarity of the zones due to refrigeration.

It is difficult to prepare the supra-occipital crests from formalin-preserved specimens. A few that had been collected in the early period of this work were washed in running water for $48 \mathrm{hr}$. and some of them were stained in alizarine according to the method of Tåning (1944). The other formalin-preserved heads were cut out behind the axil of the pectoral fins and boiled one by one in $2 \frac{1}{2} \%$ caustic soda for about $5 \mathrm{~min}$. With care and patience the supraoccipital spine could be removed from the skull, washed and air-dried. All these heads had to be cooked in boiling caustic soda or the bones of the skull never became disarticulated, and even then the results were not at all satisfactory. Usually, although the zones were quite clear, the bones showed the destructive effect of the caustic soda and were bent and curled. These bent bones did not give reliable measurements. As far as possible, therefore, a study of this type should be restricted to fresh or refrigerated specimens. If there is no choice and preserved specimens have to be dealt with, it is always best to use the alizarinestaining method. In the alizarine-stained specimens the opaque broad zones of the bone take a paler colour and rougher surface than the narrow transparent zones. Staining the bones with violet ink, indian ink and picrocarmine was tried. The inks stained the bones deeply and showed no differential shading in the staining. The picro-carmine staining was satisfactory only when the zones were clear and well defined. Dr Hart used violet ink for staining the vertebrae of Phycis blennoides and found it quite satisfactory (Menon, I950). But he is of the opinion that staining is not at all necessary if the bones can be prepared from fresh material.

The supra-occipital crest of Gadus minutus shows on its surface broad bands of opaque, white zones alternating with thin, narrow and very transparent zones. The transparent bands appear like narrow lines to the naked eye. All these bands run more or less parallel to the edge of the crest. Each opaque zone gradually passes into the next transparent zone, but each transparent zone is very abruptly succeeded by the next opaque zone. This abrupt ending of a transparent zone and beginning of the next opaque zone is marked by a well-defined line. The innermost opaque zone of the crest is paler in colour and less opaque than the other opaque zones.

Each supra-occipital has four borders: an anterior border which enters into the interlocking joint with the frontal portion of the crest, an ascending dorsal border, a descending posterior border and a ventral border by means of which it joins with the supra-occipital bone in the skull. The ventral border is not straight but is bent at about the middle to form an anterior ' ascending half' and a 'posterior descending' half. The anterior border is comparatively very 
small, so that the whole bone presents a triangular appearance with the base showing a median bend. Just behind the junction of the descending and ascending halves of the ventral border there is a point on the 'base-line' wherefrom arise several radiating lines and ridges which run towards the outer edge of the crest. In some bones these lines stand out as radiating rough ridges, but they do not interfere with the clarity of the zones or with the measurements. The posterior edge of the dorsal border is wavy or frilled in outline. This is the 'growing edge'. The point from which the radiating lines and ridges arise is the 'centre of growth' and the lines are the 'axes of growth' of the bone.

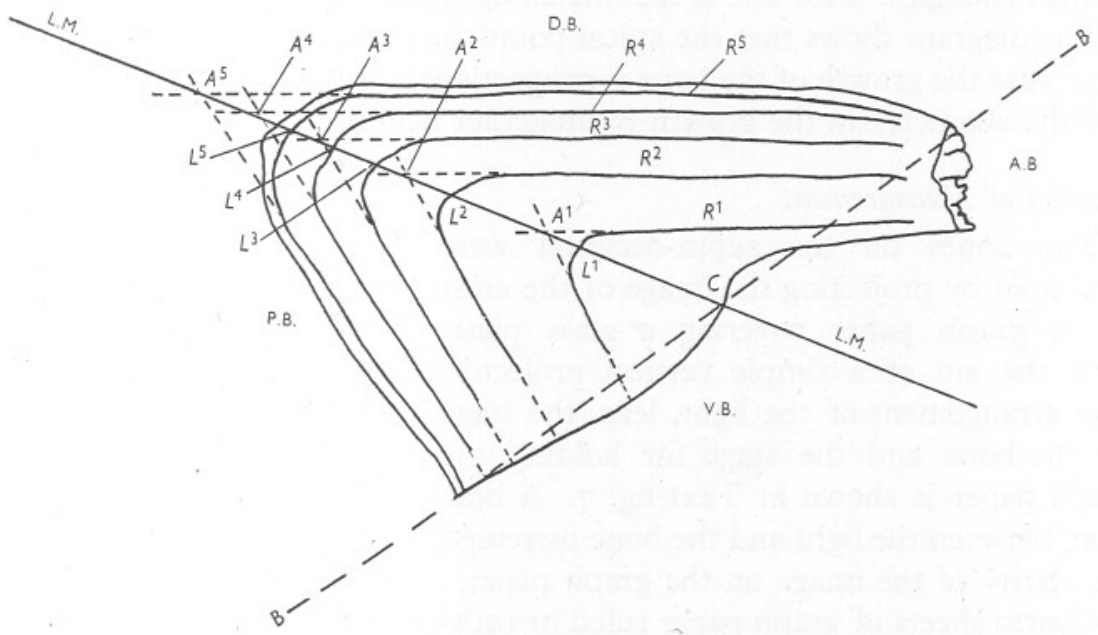

Text-fig. 6. Diagram of the theoretical projection of the rings into hypothetical triangles to fix the line of measurement on the supra-occipital crest. $B-B$, the hypothetical base-line; $R^{1}$ to $R^{5}$, the annual rings (outer limits of the transparent zones); $C$, the centre of measurements; $A^{1}-A^{5}$, the apical points of the hypothetical triangles; $L^{1}-L^{5}$, the points on the annual rings to which the measurements are made from the centre along the 'line of measurement' (L.M.). A.B., D.B., P.B., V.B., the anterior, dorsal, posterior, and ventral borders of the crest, respectively.

\section{Line of Measurement}

In utilizing a bone for the determination of age and rate of growth, the fixing of the line of measurement or axis of measurement is of prime importance. The line of measurement chosen for the supra-occipital crest is shown in Text-fig. 6. This axis of measurement was chosen because, apart from its convenience, (i) it is the median lying between the axis of vertical growth and the axis of horizontal growth of the fish and of the bone, and is therefore likely to give only the smallest error in calculations; and (ii) if all the zones are theoretically projected into hypothetical triangles this is the line which lies nearest to all the apical points and hence is to be regarded as the average of the sum forces of the axis of growth. In Text-fig. 6 it is shown how these 
zones can be hypothetically projected into triangles. Since the anterior border of the crest is comparatively very small, the crest as a whole may be regarded as a triangle. The descending half of the ventral border is projected forward as a straight line meeting the anterior end of the dorsal border, and this forms the base-line of the triangle. Then the dorsal and posterior borders of the crest are projected in straight lines until they meet usually just behind the growing edge. This is the apex of the triangle. In the same way the dorsal and posterior borders of each of the transparent bands are projected to form hypothetical triangles. A line is drawn from the centre of growth passing along an axis which is nearest to the apical points of all the projected hypothetical triangles. This line is the line along which measurements were taken.

The diagram shows that the apical points lie almost in a straight line. This is because the growth of the bone is proportionate with the growth of the head and the allometry in the growth is altogether neglible.

\section{Method of Measurement}

The zones on the supra-occipital were measured by projecting the image of the crest on to graph paper covering a glass plate, with the aid of a simple vertical projector. The arrangement of the light, lens, the stage for the bone and the stage for holding the graph paper is shown in Text-fig. 7. A blue filter between the light and the bone increased the clarity of the image on the graph paper.

Quarto sheets of graph paper ruled in Ioths of an inch proved best for making the measurements. Each inch line is assumed as a separate ordinate and each such ordinate is used for a separate bone. The point of intersection between each such ordinate and the abscissa is taken to mark the centre of growth of the bone and the starting-point of the measurements. This point is superimposed on the centre of growth of the bone in the image. Fixing the graph paper at that point the paper is slightly rotated until the ordinate of that point lies in a line over the accepted axis of measurement of the bone in the image. The

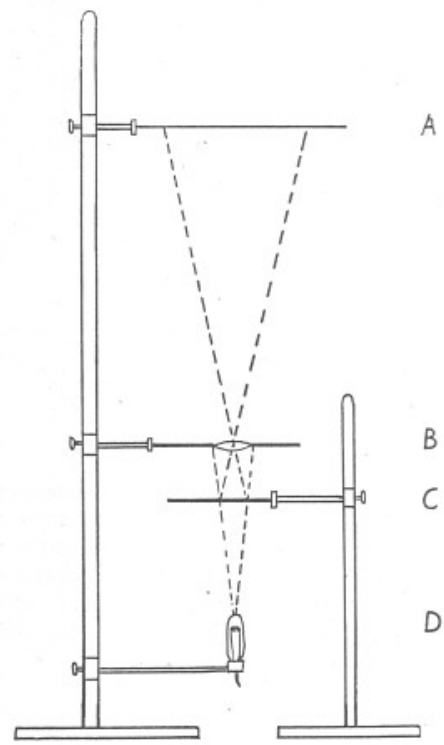

Text-fig. 7. Diagram of the simple vertical projector used for projecting the supra-occipital crests and for measuring them. $A$, stage for holding the graph paper and catching the image; $B$, the lens; $C$, stage for holding the bone; $D$, 6-watt lamp. points at which each 'annual ring' (the sharp beginning of each opaque zone) in the image cuts the ordinate on the paper are then marked with a pencil. The posterior edge of the crest also is marked on the ordinate. The scale of magnification can be found by projecting a millimetre scale to the same 
magnification on the graph paper. Knowing the magnification, the measurements of the zones on the graph paper can be easily converted into absolute measurements. When the various crests are all measured and marked on the graph paper, as described, it will be found that the respective annual-zonepoints of the various crests lie more or less in a straight line. The crests were magnified to about eight times their normal size. With this magnification the percentage of error seems very small.

A few of the bones showed false rings-usually as 'split' or 'doubled' rings. These can be easily distinguished by the split not being continuous throughout the rings. The very few false rings where there was no 'doubling' could be distinguished by weak and incomplete formation, and by abrupt change from opaque to transparent zone, not gradual as with true rings. These were most easily detected in reflected light using a black background.

\section{Validity of the annual nature of the zones}

Graham (I929b), Sund (I927), Hickling (I933), Dannevig (I933) and Le Cren (I947) have all examined the validity of age-determination by scales, otoliths and bones respectively. Graham and Sund based their studies on the agedetermination of cod on scales only, discarding the use of the skeletal parts because of the convincing evidence they got for the validity of the scale method. Hickling used only otoliths for the determination of the age of the hake and he had substantial evidence for its application and validity. The scales and otoliths of the Norwegian cod were critically studied by Dannevig (1933), and he came to the conclusion that 'the age of cod... certainly can be computed by scales and particularly by the otoliths'. The annual nature of the zones on the operculum of the Windermere perch was substantiated by Le Cren (I947).

According to Graham (I929 c), there are five tests for deciding the validity of any method of age determination in fishes:

(i) Agreement with Petersen's method.

(ii) Seasonal record of the ring or zone formation.

(iii) Observation of a stock over a long period of years.

(iv) Marking experiments.

(v) Tank or pond experiments with fish of known age.

The present investigation of $G$. minutus covers only a period of 15 months and so it is not possible to examine the validity of the method of age determination employed from the aspect of test 3. Tests 4 and 5 were not possible for several reasons, and so it has been possible only to apply the remaining two tests to the validity of the present method.

\section{Seasonal record}

This test consists in the observation of the nature of the margin of the supra-occipital crest throughout the year, to find out and establish the period of formation of the opaque and transparent zones, and thus to determine 
whether in the course of I year one opaque zone and one transparent zone only are laid. Graham (I929a) and Hickling (1933) remark that the seasonal record is a convincing test for the validity of the method. But neither of them found a sharp and complete turn over from one kind of marginal zone to the other at any time in the year. Hickling (1933) states: 'It is true that a sharp turn over from one margin to the other is completely lacking. No sample had $100 \%$ of its otoliths with an opaque zone at the edge and none had $\% \%$.'

The percentages of supra-occipital crests of $G$. minutus with the opaque zones and transparent zones at the margin respectively for each month of the period of investigation are given in Table XI and in Text-fig. 8.

It can be seen from Table XI that in no month has there been a sample with $100 \%$ of the supra-occipital crests with either opaque zone or transparent zone at the margin. The maximum and minimum percentages of supraoccipital with the opaque and transparent zones have been 86 and 3I, and 69 and I4 respectively. Hickling (I933) attributed the lack of complete turn over from one type of margin to the other in the otolith of the hake to the formation of 'subsidiary rings' in the growth of otolith as a normal feature. In the cod of Norwegian waters, on the other hand, Dannevig (1933) found a complete turn over from one type of margin to the other in both scales and otoliths. According to Hickling (1933) the causative factor for the ring formation in the otolith of the hake is an internal one and the nature of the zones depends on the condition of the fish and seasonal rate of growth of fish. Dannevig (I933) has suggested that the zone formation 'may be due to the variation in the quantity of organic substances'. The zones in the scales of cod, according to him, may 'originate in different ways by moderately low or very high temperature'.

The data of the supra-occipital crests of G. minutus show that the percentage of these crests with an opaque zone at the margin remains fairly high from January to August. This percentage is low from September to November, the lowest being in the month of October. Hickling (1933) also got more or less identical results with the hake otolith. It was found that although there was no sharp turn over in the nature of the marginal zone at any particular period of the year, there were two distinct periods when the major emphasis was for the formation of one or the other type of zone. Thus the major period for laying the opaque zone is from January to August and that for the transparent zone is from September to November.

The results of the analysis of the margin of the supra-occipital crest are shown in Text-fig. 9. In addition two other factors, the condition factor $K$ for the fish in each month, and the average volume of food in the stomachs of ten fish in each month, have been included for comparison. The condition factor $K$ used is the average for fish of all length groups and of both sexes together. Hickling (1933), in a similar study, treated the otolith data without taking sex into consideration and then compared it to the condition factor of 
Table Xi. Percentage of Fish with Opaque or Transparent ZONES at THE MARgIN OF THE SUPRA-OCCIPITAL CREST

The figures in brackets are the actual number of crests examined having the respective type of zone at the margin.

$\begin{array}{lcc}\text { Month } & \begin{array}{c}\text { Percentage of crests } \\ \text { with opaque zone at } \\ \text { the margin }\end{array} & \begin{array}{c}\text { Percentage of crest } \\ \text { with transparent } \\ \text { at the margin }\end{array} \\ \text { May I948 } & 86(68) & \text { I4 (II) } \\ \text { June } & 68(76) & 32(36) \\ \text { July } & 55(34) & 45(28) \\ \text { Aug. } & 58(77) & 42(55) \\ \text { Sept. } & 48(67) & 52(72) \\ \text { Oct. } & 31(32) & 69(70) \\ \text { Nov. } & 44(5 \mathrm{I}) & 56(66) \\ \text { Dec. } & 53(49) & 47(43) \\ \text { Jan. I949 } & 58(\mathrm{I} 35) & 42(98) \\ \text { Feb. } & 52(\mathrm{II}) & 48(\mathrm{IIO}) \\ \text { Mar. } & 57(\mathrm{I} 3 \mathrm{I}) & 43(96) \\ \text { Apr. } & 6 \mathrm{I}(92) & 39(59) \\ \text { May } & 70(\mathrm{III}) & 30(47) \\ \text { June } & 73(5 \mathrm{I}) & 27(\mathrm{I})\end{array}$

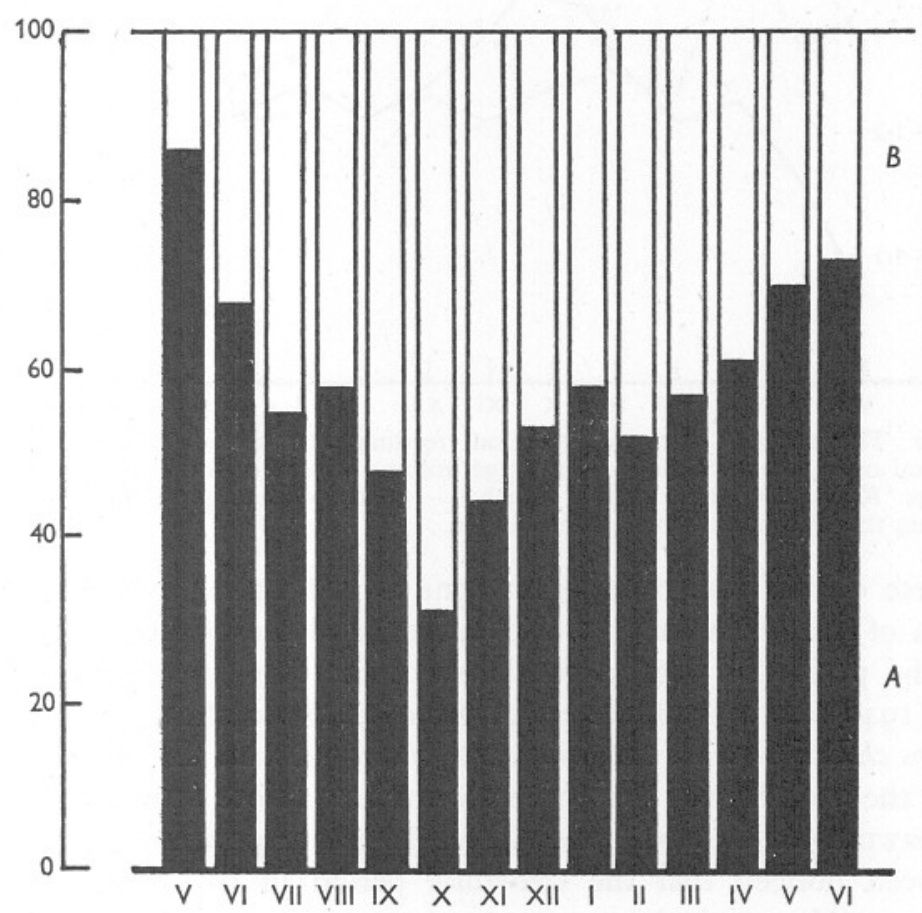

Text-fig. 8. Histogram showing the number of supra-occipitals per roo examined exhibiting $(A)$ the opaque zone, and $(B)$ the transparent zone respectively at their margins in successive months. 
the adolescent female hake. Although this did not lead to any conflicting results with the hake, it is better to treat such data from comparable factors and common standards when possible.

The condition factor is lowest during the spawning period February to May. This is the main period of formation of the opaque zone on the supraoccipital crests. Hickling (I933) found that 'the transluscent band is laid on the otolith of the hake at the time of the poorest condition, that is, of greatest physiological stress. In mature fish this is the exhaustion due to spawning and in immature fish to its precursor in the innate physiological rhythm which can be detected in the somatic tissues.' The observations on G. minutus show just

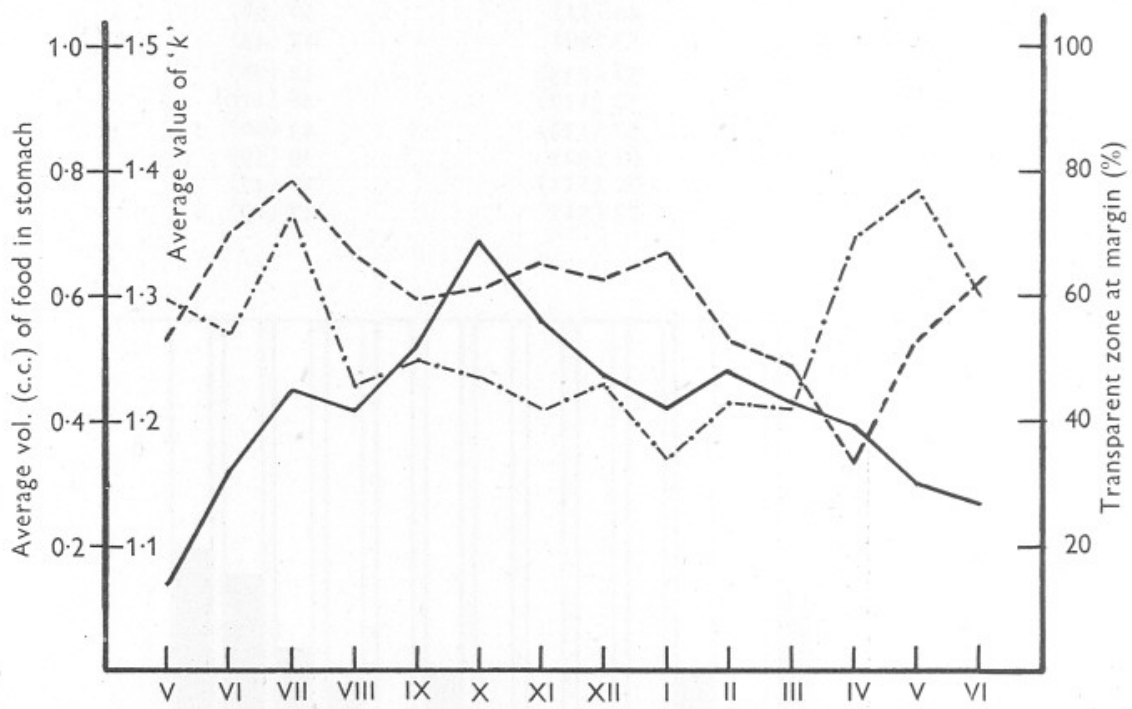

Text-fig. 9. The relation between condition, feeding, and zone formation in the supraoccipital of G. minutus. -...-.-, average volume in c.c. of food per stomach; -.----, average ' $K$ ' for the whole sample of fish; _- , the percentage of supra-occipital crests showing the transparent zone at the margin.

the reverse of this: the transparent zone is laid during a period of normal condition of fish (September to November) and the opaque zone is formed during the period of poorest condition of the fish (the spawning period). Yasuda (I940) made a similar observation on the otoliths and vertebrae of Scombrops chilodipteroides and Theragra chalcogramma. He observed that the rings on the otoliths and vertebrae are formed before spawning-3 months before spawning on the otolith and $\mathrm{I} \frac{1}{2}$ months before spawning on the vertebrae. It has been noticed that the spawning period in Gadus minutus is from February to May and the transparent zone (the counterpart of Yasuda's 'rings') is laid on the supra-occipital crest from September to November, i.e. the transparent zone is laid nearly 4-6 months after the spawning or, conversely, it is laid $2-4$ months before the next spawning. If were are to accept 
Hickling's (1933) finding that the fluctuation in the 'physiological stress' is the causative factor for the zone formation in the skeletal parts, it will have to be assumed that the effect of the physiological stress becomes apparent on the supra-occipital crest of $G$. minutus only some months after its actual occurrence.

Taking the average volume of food (Table I, p. I89) into consideration, we find that there is not much of a correlation with the zone formation. The highest percentage of supra-occipital crests with opaque zone at the margin is found during the period of 'most active feeding' and the lowest percentage of opaque-zone formation occurs during the period of 'average feeding'. But the correlation ends with this.

It appears that of these two factors-the physiological stress and feedingthe physiological stress is the more acceptable as the causative factor for the formation of the 'ring'. The effect of the physiological stress is made apparent on the bone as the transparent zone.

Without going further into the question on the causative factor, we find that the zones are annual, being laid at definite periods of the year and can be used as valid indices of age in G. minutus.

\section{Agreement with Petersen's Method}

This test is useful only if the following conditions are satisfied: (i) the sample analysed must be large; (ii) the samples must contain all the year groups in a proportion at least fairly comparable with their proportion in the population; (iii) the Petersen graph of the size analysis must show reasonably distinct modes.

Graham (1929c) has pointed out that the test is applicable to the first three or four age groups, and he further asserts that even in cases of agreement it only confirms the correctness of the method of age assessment for a fair majority of the fish.

Examining these three conditions of the utility of this test one notes that the first condition has no limiting factor. The bigger the sample, the closer is the approximation to the truth. There is no absolute criterion of the probable number in the sample to satisfy the condition. With regard to the third condition, only the modes of the early years will be distinct and well defined. As the rate of growth decreases with age the differences in the lengths of older age groups become very small and the Petersen curve tends to flatten at these later age groups. In fishes which have a short span of life this flattening of the curve may occur even earlier.

The second condition is especially important. The curve is one that represents the percentage composition of the length groups in a sample of population. The sample, therefore, should contain primarily all the year groups and, secondly, should contain them in such numbers that are proportionally comparable to their numbers in the population. In actual practice it is always possible that the gear employed for the collection of the samples 
introduces a certain amount of selection in the sampling. In Text-figs. Io and II, showing the monthly analysis of the length groups of the G. minutus examined, the curve shows a very disturbing character, namely the absence of the O-group and I-group in the earlier samples. This is due to the selective

\begin{tabular}{|c|c|c|c|c|c|c|c|c|c|c|c|c|c|c|c|}
\hline \multirow{2}{*}{$\begin{array}{l}\text { Length } \\
\text { of } \\
\text { fish } \\
\text { in } \\
\mathrm{cm} .\end{array}$} & \multicolumn{9}{|c|}{$\underbrace{\text { I948 }}$} & \multicolumn{6}{|c|}{$\underbrace{1949}$} \\
\hline & Apr. & May & June & July & Aug & Sept & Oct. & Nov. & Dec. & Jan. & Feb. & Mar. & Apr. & May & June \\
\hline 7 & $\cdots$ & $\cdots$ & . & $\cdots$ & . & $\cdots$ & I & 96 & $\cdots$ & $\cdots$ & I3 & 6 & . & $\because$ & $\therefore$ \\
\hline 8 & $\cdots$ & . & $\cdots$ & $\cdots$ & $\cdots$ & $\cdots$ & 2 & I8 & $\cdots$ & 9 & 89 & 35 & $\cdots$ & I4 & $\cdots$ \\
\hline 9 & $\cdots$ & $\cdots$ & $\cdots$ & $\cdots$ & $\cdots$ & $\cdots$ & I & I5 & $\cdots$ & 3 & 77 & 24 & I & I9 & $\cdots$ \\
\hline IO & $\because$ & $\ddot{\sigma}$ & $\cdots$ & $\cdots$ & $\cdots$ & $\cdots$ & 7 & I4 & $\cdots$ & 4 & 4I & 9 & 8 & 24 & 6 \\
\hline II & 2 & 6 & 4 & . & $\cdots$ & $\cdots$ & . & . & . & 2 & II & I & II & 6 & 29 \\
\hline 12 & 3 & I4 & I I & $\ddot{x}$ & 2 & $\cdots$ & . & $\cdots$ & . & 5 & 2 & 3 & 8 & 9 & 33 \\
\hline I3 & $2 \mathrm{I}$ & 29 & 74 & 6 & I3 & 2 & 4 & $\cdots$ & $\cdots$ & 9 & 3 & 6 & 5 & 9 & II \\
\hline I4 & 45 & 47 & 70 & 30 & 34 & 34 & I4 & 22 & I4 & 4 & 38 & I4 & 33 & 49 & I7 \\
\hline I5 & 13 & 42 & 57 & 49 & 53 & 60 & I6 & 22 & 6 & 29 & I & I2 & I6 & 33 & 33 \\
\hline I6 & I5 & 43 & $5 \mathrm{I}$ & 32 & 59 & 42 & 25 & 47 & II & 23 & 28 & I8 & 48 & I9 & 30 \\
\hline I7 & 5 & 25 & I3 & 42 & 55 & 53 & 46 & 38 & 49 & II & 36 & I7 & 63 & 37 & I4 \\
\hline I8 & 4 & I7 & 20 & 29 & $3 I$ & I3 & 39 & 9 & I5 & 7 & I I & 8 & 25 & I2 & 8 \\
\hline I9 & 6 & 4 & 4 & I8 & 22 & 5 & I6 & 6 & 3I & .. & 6 & 6 & IO & 7 & $\cdots$ \\
\hline 20 & $\cdots$ & $\cdots$ & . & 8 & II & . & $\cdots$ & . & 6 & $\cdots$ & 3 & $\cdots$ & 2 & 4 & $\cdots$ \\
\hline $2 I$ & $\cdots$ & $\cdots$ & $\cdots$ & 3 & 3 & $\cdots$ & I & . & 4 & $\cdots$ & $\cdots$ & $\cdots$ & $\because$ & $\cdots$ & $\cdots$ \\
\hline 22 & $\cdots$ & $\cdots$ & $\cdots$ & $\cdots$ & $\cdots$ & . & $\cdots$ & . & $\cdots$ & $\cdots$ & $\cdots$ & . & I & . & $\cdots$ \\
\hline \multirow[t]{2}{*}{23} & $\cdots$ & $\cdots$ & $\because$ & $\because$ & $\ddot{\theta}$ & $\because$ & $\because$ & $\because$ & $\ddot{*}$ & 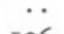 & $\because$ & $\cdots$ & 2 & $\cdots$ & 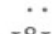 \\
\hline & II 4 & 227 & 304 & 217 & 283 & 2099 & I 72 & 287 & 136 & I06 & 370 & I59 & 233 & 242 & I8I \\
\hline
\end{tabular}

Table XIII. Table Showing the Monthly Analysis of the Size Length
of OF THE Specimens Examined. Male

\begin{tabular}{|c|c|c|c|c|c|c|c|c|c|c|c|c|c|c|c|}
\hline fish & & & & & I 948 & & & & & & & & 49 & & \\
\hline 1. & pr. & May & June & July & Aug & Sept. & Oct. & Nov. & Dec. & Jan. & $\mathrm{Feb}$ & $\mathrm{Ma}$ & Apr & May & ur \\
\hline 7 & . & . & $\cdots$ & . & . & . & $\cdots$ & 9 & . & . & I4 & $\ddot{x}$ & . & . & . \\
\hline 8 & $\cdots$ & $\cdots$ & $\cdots$ & . & . & . & . & 4 & . & . & & 36 & . & & . \\
\hline 9 & $\cdots$ & $\cdots$ & $\cdots$ & . & $\cdots$ & $\cdots$ & I & 3 & . & 2 & 76 & 26 & 2 & IO & . \\
\hline IO & $\cdots$ & $\because$ & $\cdots$ & $\cdots$ & . & $\cdots$ & 3 & $\cdots$ & $\cdots$ & 7 & 39 & II & 5 & 3 & 4 \\
\hline & $\ldots$ & I8 & 9 & . & . & . & I & 2 & $\cdots$ & 2 & 5 & 6 & 3 & $\ldots$ & I 2 \\
\hline 1 & 5 & 3 & 25 & 4 & 2 & $\cdots$ & . & $\cdots$ & $\cdots$ & 2 & 4 & II & 6 & 7 & 7 \\
\hline I & 24 & I4I & 34 & 9 & 3 & II & 4 & 8 & I 1 & 23 & 28 & 36 & 28 & 2 & I8 \\
\hline I & 21 & 5 & 59 & I4 & I 4 & $2 \mathrm{I}$ & 3 & I6 & 9 & 47 & I7 & I2 & I7 & 22 & I7 \\
\hline Is & 7 & 29 & 28 & I8 & 25 & 25 & IC & I5 & 6 & 39 & $2 I$ & 33 & 40 & 23 & 9 \\
\hline I & $\cdots$ & II & 7 & 8 & II & I3 & I2 & $2 \mathrm{I}$ & . & 5 & 2 & 5 & 3 & 3 & 2 \\
\hline I & $\cdots$ & $\cdots$ & 5 & 4 & I & IO & 5 & $\cdots$ & $\cdots$ & $\ldots$ & . & $\cdots$ & I7 & 5 & . \\
\hline & $\cdots$ & $\cdots$ & $\cdots$ & $\cdots$ & 2 & 2 & $\cdots$ & $\cdots$ & $\cdots$ & . & $\cdots$ & $\cdots$ & $\cdots$ & $\cdots$ & . \\
\hline & $\cdots$ & 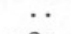 & $\because$ & $\cdots$ & I & 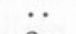 & I & $\cdots$ & $\cdots$ & $\cdots$ & $\cdots$ & $\cdots$ & $\cdots$ & $\cdots$ & $\cdots$ \\
\hline & 57 & 285 & I67 & 57 & 59 & 82 & 46 & 78 & 26 & I27 & 301 & I76 & I2I & II 4 & 69 \\
\hline
\end{tabular}

sampling by the gear (Tables XII and XIII). Throughout the investigation the main gear used for the collection of the samples was the otter trawl, which would be liable to select against the smaller size groups. This is clearly seen in the earlier part of the investigation in which the O-group was completely lacking. Later it was possible to collect a few of the O-group specimens from 


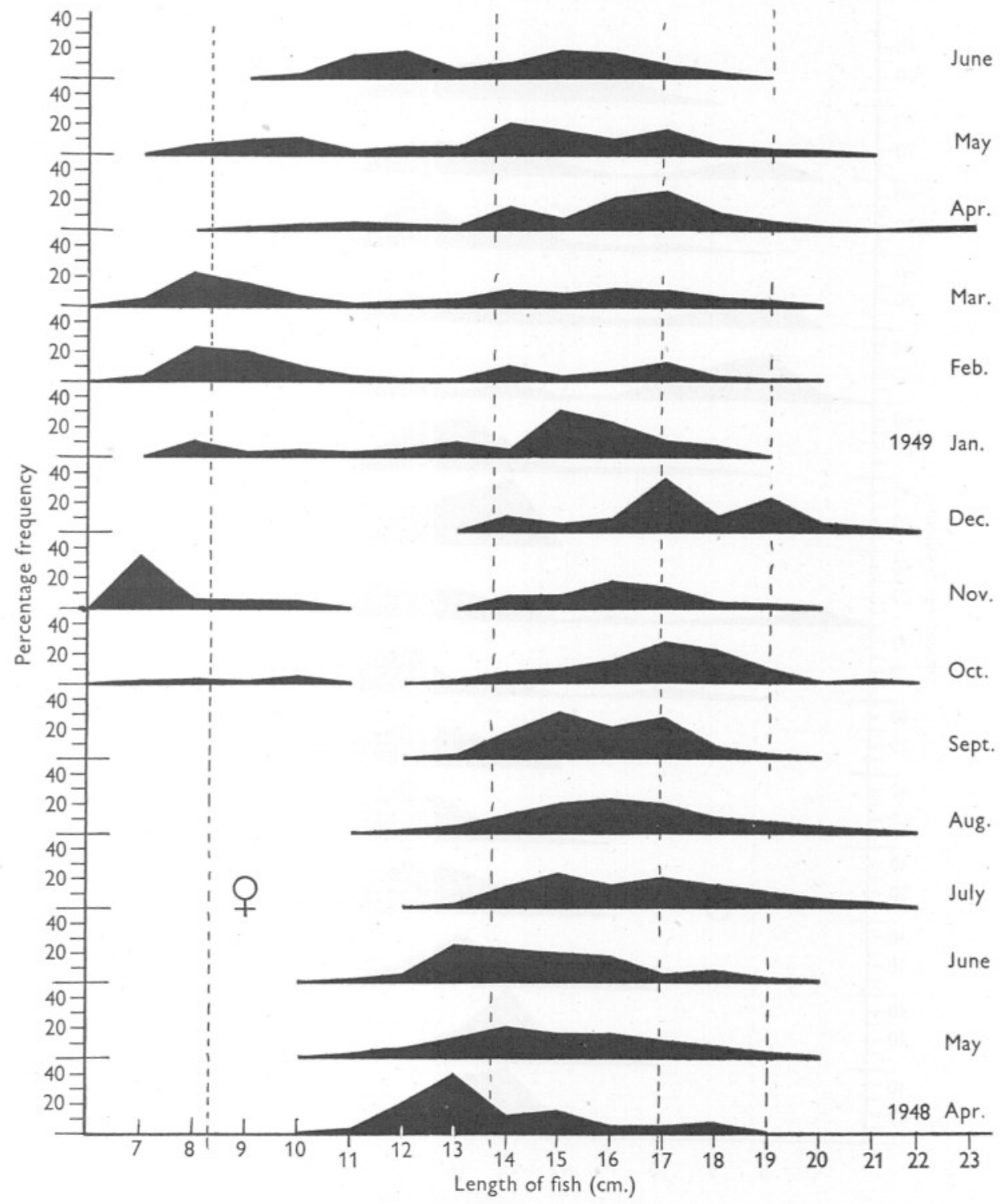

Text-fig. Io. The size-composition (length-frequency) of the females in the samples of G. minutus in successive months. -----, the yearly lengths back-calculated from the supra-occipital crests. 


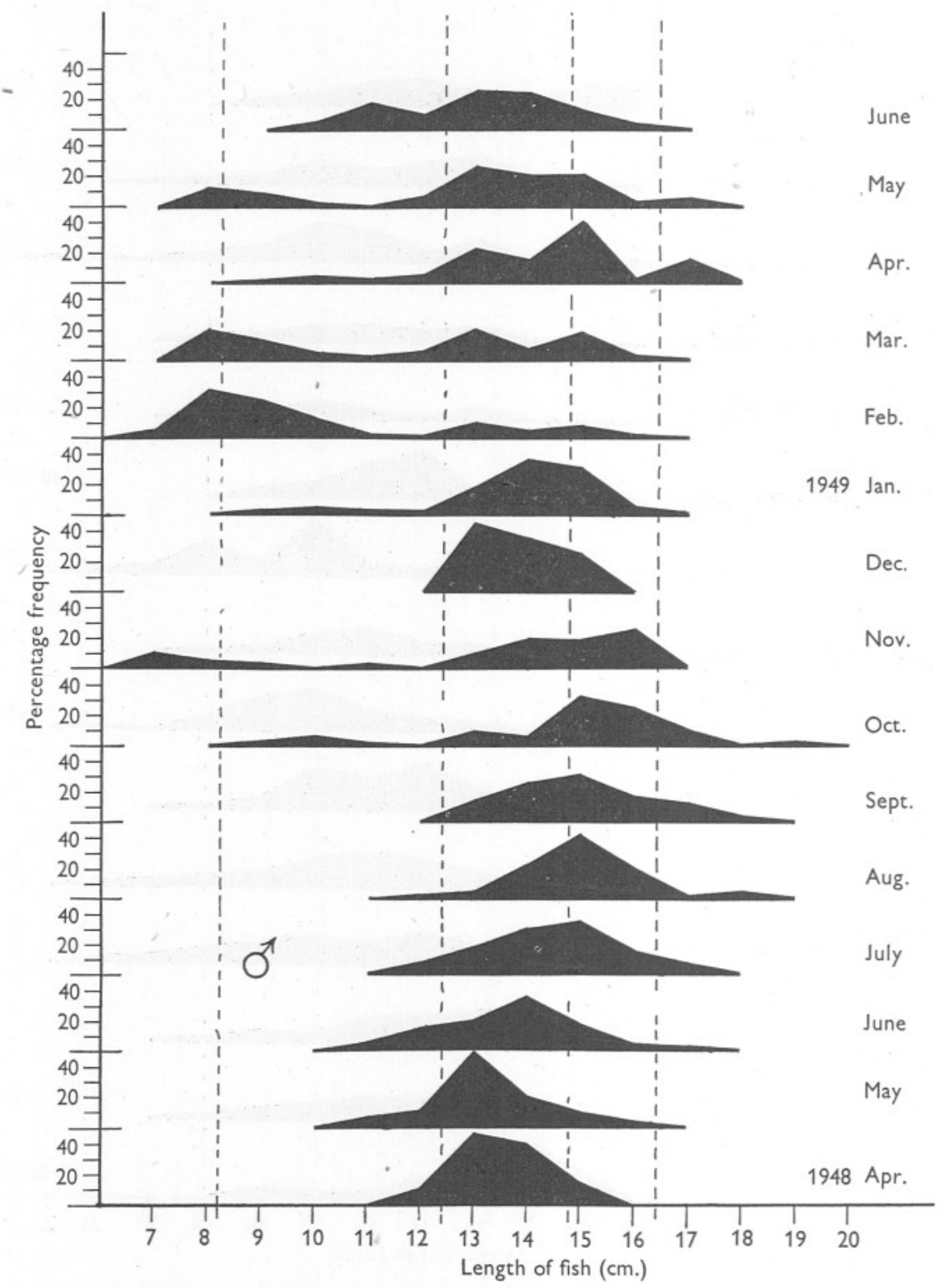

Text-fig. Ir. The size-composition (length-frequency) of the males in the samples of G. minutus in successive months. --.---, the yearly lengths back-calculated from the supra-occipital crests. 
the trawling surveys of Mr P. G. Corbin, who used the ordinary otter trawl with a sprat-net cod-end. All these have been included in the graphs. Also plotted on the graphs are the lengths that the fish reaches at the end of each year calculated from the supra-occipital. These are shown as vertical lines at the respective 'calculated lengths'. The spawning period of the fish is from February to May with its maximum in April. It can then be assumed that this period is the initial starting-point of the annual growth. It can be seen from the graphs that the first mode of the curves in the graphs for January, February and March in the female, and February, March and May in the male, lie more or less on the calculated lengths. In November 1948, another month when some specimens of $\mathrm{O}$ - and I-groups were obtained, the first mode lies much in front of the calculated length for the first year. The 2nd year and 3 rd year modes also show more or less the same position as the calculated lengths in the months of February, March, April and May in the size-analysis graphs for both male and female. It is not possible to follow one lower-age

\begin{tabular}{|c|c|c|c|c|}
\hline \multirow[b]{2}{*}{$\begin{array}{l}\text { At the } \\
\text { end of }\end{array}$} & \multicolumn{3}{|c|}{ TABLE XIV } & Female \\
\hline & $\begin{array}{c}\text { Mode or } \\
\text { observed } \\
\text { length in } \mathrm{cm} .\end{array}$ & $\begin{array}{l}\text { Calculated } \\
\text { length in cm. } \\
\text { (from supra- } \\
\text { occipital) }\end{array}$ & $\begin{array}{c}\text { Mode or } \\
\text { observed } \\
\text { length in } \mathrm{cm} \text {. }\end{array}$ & $\begin{array}{l}\text { Calculated } \\
\text { length in cm. } \\
\text { (from supra- } \\
\text { occipital) }\end{array}$ \\
\hline Ist year & 8 & $8 \cdot 2$ & 8 & $8 \cdot 3$ \\
\hline 2nd year & I3 & I $2 \cdot 4$ & I4 & 13.7 \\
\hline 3 rd year & 15 & 14.8 & I7 & $\begin{array}{l}16.9 \\
\end{array}$ \\
\hline
\end{tabular}

class throughout the year in the graphs due to the influence of selective sampling by the gear. But the close approximation of the first three modes to the calculated lengths for the first 3 years in the months of February to May, in general, is a fair vindication of the test and the validity of the method (see Table XIV). Considering that the modes are given only to the nearest $\mathrm{cm}$. the agreement is as exact as can be expected.

\section{Age and Rate of Growth of GadUs MINUTUS}

The above two tests have substantially confirmed that the zones are annual and one opaque zone and its immediately succeeding transparent zone denote I year's growth and that they are the 'annual rings' comparable to the annual rings of the scales and otoliths of other fishes.

The mean lengths of the supra-occipital crest at each $5 \mathrm{~mm}$. body-length in the male and female respectively are given in Table XV and plotted in Textfigs. I 2 and I3 against the respective body-lengths as correlation curves.

The mean lengths of the Ist, 2nd, 3rd rings, etc., at each respective bodylength, have been included in the graphs to represent the respective rings on the length-group of the supra-occipital. It can be seen from this that the lengths of each annual ring lie along a straight line, to quite a remarkable 
degree, clearly proving that the rings once formed did not show any addition or diminution in their sizes and quality. The back-calculation was done in two ways - graphically and by the Lea-Dahl formula. The graphical back-calculation was carried out as follows.

Table XV. Table showing the Length of the Supra-Occipital Crest AT THE DifFerent LeNGTHS OF Fish

Length of the supra-occipital crest in mm.

\begin{tabular}{|c|c|c|c|c|c|c|}
\hline \multirow[b]{2}{*}{$\begin{array}{l}\text { Length } \\
\text { of fish } \\
\text { in } \mathrm{cm} \text {. }\end{array}$} & \multicolumn{3}{|c|}{ Female } & \multicolumn{3}{|c|}{ Male } \\
\hline & $\begin{array}{c}\text { Empirical } \\
\text { mean } \\
\text { lengths }\end{array}$ & $\begin{array}{l}\text { S.E. of } \\
\text { mean }\end{array}$ & $\begin{array}{l}\text { Theoretical } \\
\text { lengths } X\end{array}$ & $\begin{array}{l}\text { Empirical } \\
\text { mean } \\
\text { lengths }\end{array}$ & $\begin{array}{l}\text { S.E. of } \\
\text { mean }\end{array}$ & $\begin{array}{l}\text { Theoretical } \\
\text { lengths } Y\end{array}$ \\
\hline $7 \cdot 0$ & $2 \cdot 8 \mathrm{I}$ & 0.029 & 2.69 & $2 \cdot 78$ & 0.033 & $2 \cdot 69$ \\
\hline $7 \cdot 5$ & 3.07 & 0.033 & 2.97 & $2 \cdot 99$ & 0.024 & 2.97 \\
\hline 8.0 & 3.38 & 0.031 & $3 \cdot 24$ & 3.32 & 0.028 & $3 \cdot 24$ \\
\hline $8 \cdot 5$ & 3.60 & 0.034 & 3.52 & $3 \cdot 44$ & 0.017 & 3.52 \\
\hline $9 \cdot 0$ & $3 \cdot 83$ & 0.026 & $3 \cdot 7 \mathrm{I}$ & $3 \cdot 72$ & 0.033 & $3 \cdot 79$ \\
\hline 9.5 & 3.99 & 0.033 & 4.03 & 3.98 & 0.038 & 4.07 \\
\hline 10.0 & $4 \cdot 4 \mathrm{I}$ & 0.033 & $4 \cdot 34$ & $4 \cdot 36$ & 0.037 & $4 \cdot 34$ \\
\hline 10.5 & $4 \cdot 79$ & 0.020 & 4.66 & $4 \cdot 57$ & 0.035 & 4.62 \\
\hline II.O & 4.96 & 0.039 & 4.98 & 5.01 & 0.026 & $4 \cdot 89$ \\
\hline II 5 & $5 \cdot 21$ & 0.030 & $5 \cdot 30$ & $5 \cdot 21$ & 0.025 & $5 \cdot 16$ \\
\hline $12 \cdot 0$ & 5.58 & 0.030 & $5 \cdot 62$ & 5.42 & 0.035 & 5.44 \\
\hline I2. 5 & 5.92 & 0.047 & $5 \cdot 94$ & $5 \cdot 62$ & 0.038 & $5 \cdot 71$ \\
\hline 13.0 & $6 \cdot 32$ & 0.031 & $6 \cdot 25$ & 6.04 & 0.032 & 5.99 \\
\hline 13.5 & $6 \cdot 60$ & 0.039 & 6.57 & $6 \cdot 30$ & 0.035 & $6 \cdot 26$ \\
\hline 14.0 & $6 \cdot 8 I$ & 0.083 & 6.89 & $6 \cdot 68$ & 0.042 & $6 \cdot 54$ \\
\hline 14.5 & $7 \cdot 12$ & 0.052 & $7 \cdot 21$ & $6 \cdot 85$ & 0.035 & 6.81 \\
\hline I5.O & $7 \cdot 56$ & 0.052 & $7 \cdot 53$ & $7 \cdot 10$ & 0.038 & 7.09 \\
\hline 15.5 & $7 \cdot 85$ & 0.058 & $7 \cdot 85$ & $7 \cdot 54$ & 0.039 & $7 \cdot 36$ \\
\hline 16.0 & $8 \cdot 16$ & 0.035 & $8 \cdot 17$ & $7 \cdot 7 I$ & 0.045 & $7 \cdot 64$ \\
\hline 16.5 & $8 \cdot 66$ & 0.049 & $8 \cdot 48$ & $8 \cdot 08$ & 0.052 & $7 \cdot 91$ \\
\hline I $7 \cdot 0$ & $8 \cdot 86$ & 0.056 & 8.80 & $8 \cdot 32$ & 0.029 & $8 \cdot 19$ \\
\hline 17.5 & 9.07 & 0.082 & $9 \cdot 12$ & 8.45 & 0.039 & $8 \cdot 46$ \\
\hline 18.0 & $9 \cdot 45$ & 0.082 & $9 \cdot 44$ & 8.69 & 0.021 & $8 \cdot 74$ \\
\hline 18.5 & 9.87 & 0.074 & $9 \cdot 76$ & $(8 \cdot 88)$ & . & 9.01 \\
\hline 19.0 & IO. 24 & 0.071 & 10.08 & . & . & . \\
\hline 19.5 & 10.37 & 0.046 & 10.39 & . & . & . \\
\hline 20.0 & 10.69 & 0.064 & 10.71 & $\ldots$ & . & $\cdots$ \\
\hline $20 \cdot 5$ & II I I 3 & 0.048 & II.O3 & . & . & $\cdots$ \\
\hline $2 I \cdot 0$ & II 40 & 0.058 & II 35 & $\ldots$ & . & . \\
\hline $2 I \cdot 5$ & II. 60 & 0.067 & II 67 & . & $\ldots$ & . \\
\hline $22 \cdot 0$ & $(I I \cdot 96)$ & . & II'99 & . & . & $\ldots$ \\
\hline $22 \cdot 5$ & $(12 \cdot 26)$ & 0.010 & $12 \cdot 30$ & . & $\cdots$ & $\cdots$ \\
\hline
\end{tabular}

Notes. $X, Y$; the theoretical lengths calculated from the formulae: and

$L=3.18+\mathrm{I} \cdot 57 l$ for the females above $9.0 \mathrm{~cm}$.,

$L=2 \cdot 10+\mathrm{I} \cdot 82 l$, for the males.

The theoretical lengths for the groups below $9.0 \mathrm{~cm}$. in the females were calculated from the formulae used for the males. The empirical lengths are nearly the same in both sexes towards the lower length groups. The difference in the lengths of the supra-occipital crests in the two sexes is marked from maturity.

The figures in brackets denote that the number of crests examined were less than 5 .

The mean lengths of the Ist, 2nd, 3 rd, 4 th and 5 th 'rings' were worked out from all the supra-occipitals examined for either sex irrespective of the lengths of the fish (Table XVI). 


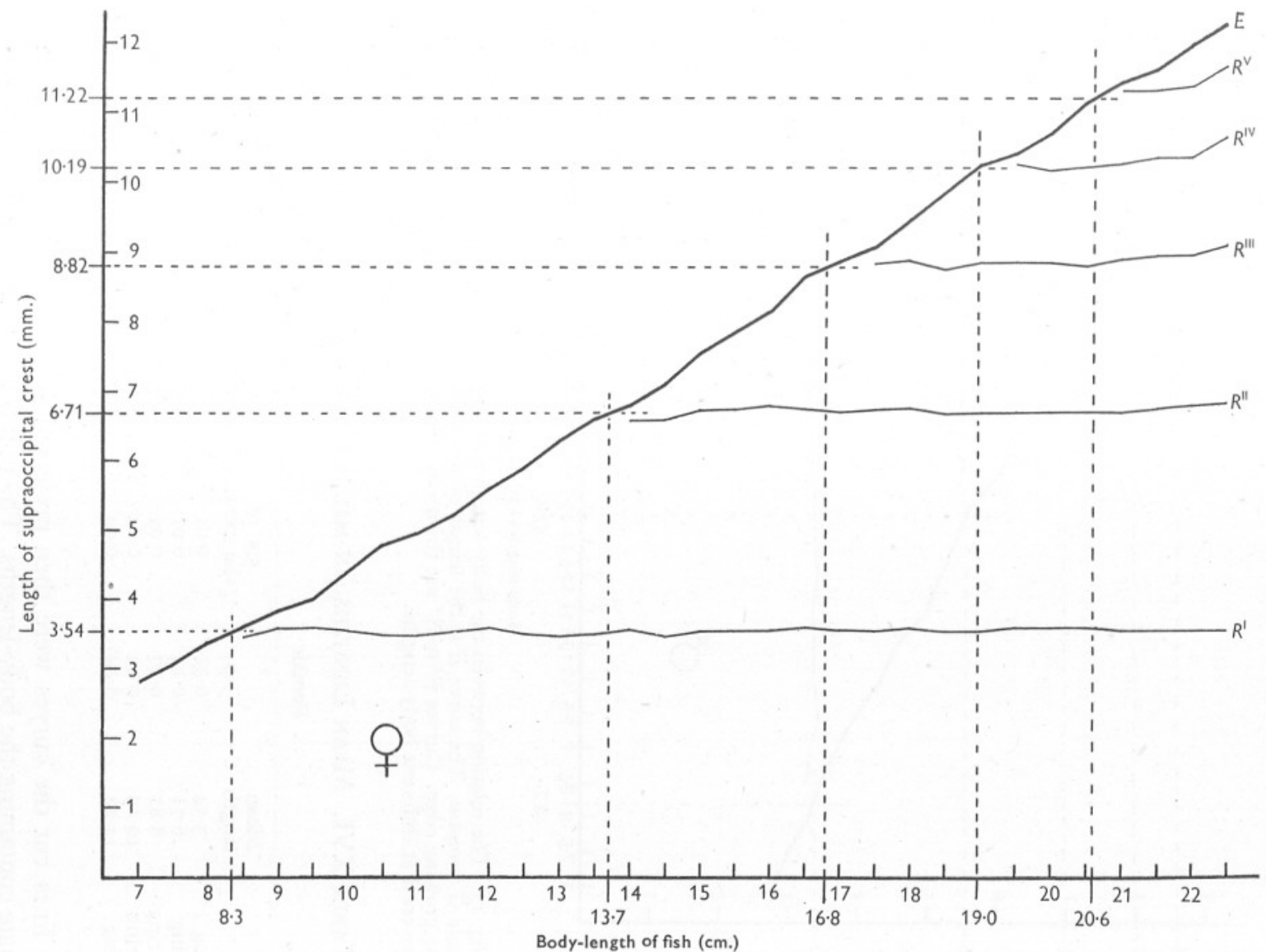

Text-fig. I2. The relation between the body-length of fish and length of supra-occipital crests in the female $G$. minutus. The curve $E$ is the length of crest from the centre of measurements to the growing edge. Curves $R^{\mathrm{I}}$ to $R^{\mathrm{V}}$ are the mean lengths of the respective annual rings on the crest at different body-lengths. 
These lengths were then plotted on the abscissa of the graph of the curve of correlation of the length of fish and length of supra-occipital crests. They were then projected straight to cut the correlation curve. The points at which

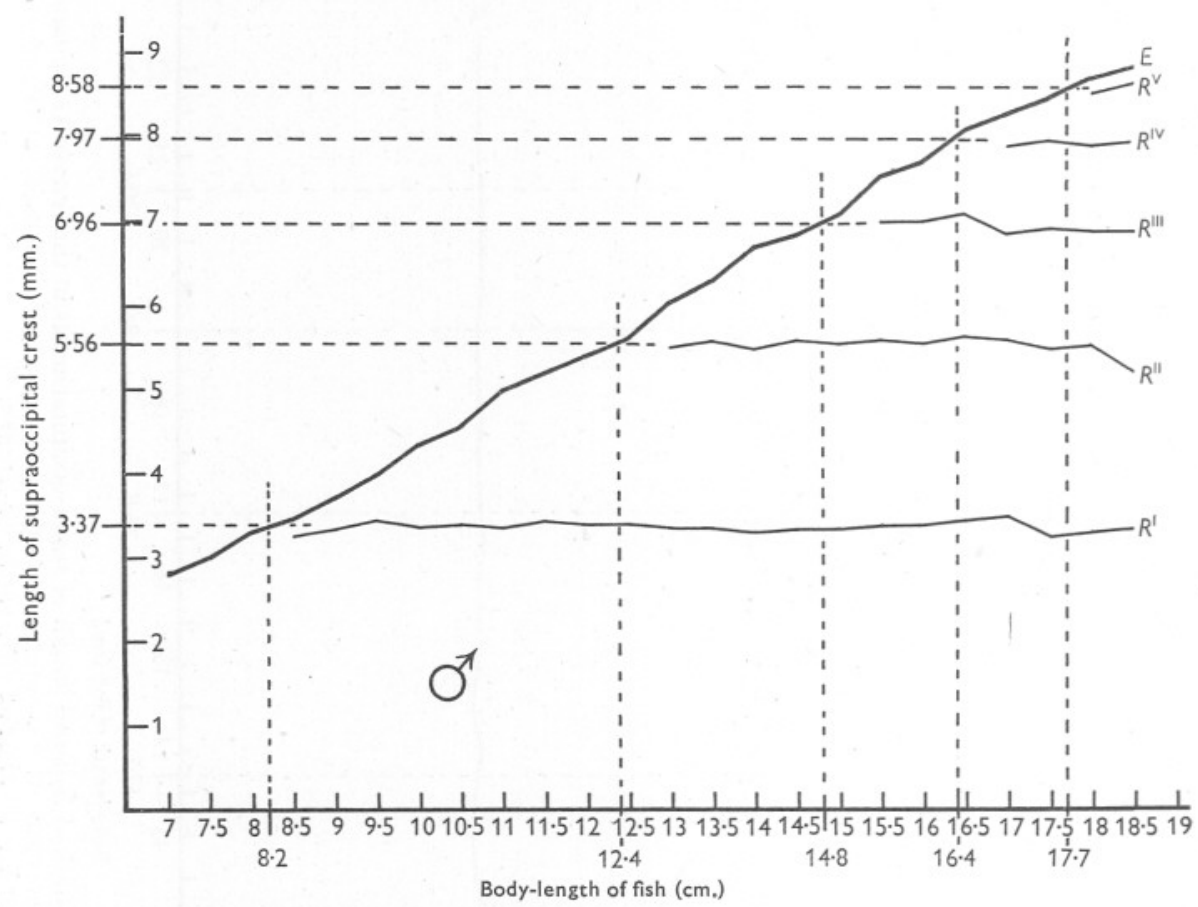

Text-fig. 13. The relation between the body-length and length of supra-occipital crest in the male G. minutus. The curve $E$ is the length of crest from the centre of measurement to the growing edge. Curves $R^{\mathrm{I}}$ to $R^{\mathrm{V}}$ are the mean lengths of the respective annual rings on the crest at different body-lengths.

Table XVI. Mean Lengths (in mm.) of Successive Annual Rings

\begin{tabular}{|c|c|c|c|c|c|c|}
\hline & \multicolumn{3}{|c|}{ Female } & \multicolumn{3}{|c|}{ Male } \\
\hline & $\begin{array}{l}\text { Mean } \\
\text { length }\end{array}$ & S.D. & $\begin{array}{l}\text { S.E. of } \\
\text { the mean }\end{array}$ & $\begin{array}{l}\text { Mean } \\
\text { length }\end{array}$ & S.D. & $\begin{array}{l}\text { S.E. of } \\
\text { the mean }\end{array}$ \\
\hline I ring & 3.54 & 0.31 & 0.01 & $3 \cdot 37$ & 0.27 & $0.0 I$ \\
\hline II ring & $.6 \cdot 71$ & 0.24 & 0.01 & $5 \cdot 56$ & 0.21 & 0.01 \\
\hline III ring & $8 \cdot 82$ & 0.27 & 0.02 & 6.96 & 0.23 & 0.02 \\
\hline IV ring & 10.19 & 0.29 & 0.04 & $7 \cdot 97$ & 0.17 & 0.03 \\
\hline $\mathrm{V}$ ring & II $\cdot 22$ & 0.14 & . 0.04 & $8 \cdot 58$ & 0.21 & $0.1 \mathrm{I}$ \\
\hline
\end{tabular}

these lines cut the curves were then projected vertically down to meet the ordinate containing the body-lengths. The points at which these vertical projections cut the ordinate denoted the 'calculated lengths' of the fish at the end of the Ist, 2 nd, 3 rd, 4 th and 5 th years respectively. The calculated lengths thus arrived at are given in Table XVII. 
The actual observations from the supra-occipital crests show slightly higher values for the body-lengths. The various $5 \mathrm{~mm}$. length groups of either sex are tabulated below according to the number of ' annual rings' or age discerned on their respective supra-occipital crests as with the scales and otoliths (Table XVIII).

Table XVII. 'Calculated Lengths', Derived from Measurements of the Supra-Occipital Crest

\begin{tabular}{lrr} 
& \multicolumn{2}{c}{ Body-length of fish in cm. } \\
\cline { 2 - 3 } At the end of & Female & Male \\
Ist year & 8.3 & 8.2 \\
2nd year & $13 \cdot 7$ & $12 \cdot 4$ \\
3rd year & $16 \cdot 9$ & 14.8 \\
4th year & $19 \cdot 0$ & $16 \cdot 4$ \\
5th year & c. 20.6 & c. $17 \cdot 7$
\end{tabular}

Table XVIII. Analysis of the Supra-Occipital Crests of Gadus MINUTUS ACCORDING TO THE LENGTH AND AgE OF THE FisH

\begin{tabular}{|c|c|c|c|c|c|c|c|c|c|c|c|c|c|}
\hline \multirow{3}{*}{$\begin{array}{l}\text { Length } \\
\text { of fish } \\
\text { in } \mathrm{cm} \text {. }\end{array}$} & \multicolumn{12}{|c|}{ Age in years } & \multirow[b]{3}{*}{ Total } \\
\hline & \multicolumn{6}{|c|}{ Female } & \multicolumn{6}{|c|}{ Male } & \\
\hline & $\mathrm{I}-$ & $I+$ & $2+$ & $3+$ & $4+$ & $5+$ & $\mathrm{I}-$ & $\mathrm{I}+$ & $2+$ & $3+$ & $4^{+}$ & $5+$ & \\
\hline $7 \cdot 0$ & 20 & . & . & $\ldots$ & . & . & II & . & . & $\cdots$ & . & . & $3 I$ \\
\hline $7 \cdot 5$ & 36 & $\cdots$ & $\cdots$ & $\cdots$ & $\cdots$ & . & I0 & . & . & . & . & . & 46 \\
\hline 8.0 & 34 & 9 & $\cdots$ & $\cdots$ & $\cdots$ & . & 36 & I & . & . & . & . & 80 \\
\hline $8 \cdot 5$ & 24 & I8 & $\cdots$ & $\ldots$ & . & $\cdots$ & 23 & 19 & . & .. & . & $\cdots$ & 84 \\
\hline 9.0 & 12 & 22 & $\cdots$ & $\cdots$ & $\cdots$ & $\cdots$ & I5 & 26 & . & . & . & $\cdots$ & 75 \\
\hline 9.5 & 6 & 34 & $\ldots$ & $\cdots$ & $\cdots$ & $\cdots$ & $\ldots$ & 32 & $\ldots$ & $\cdots$ & . & $\cdots$ & 72 \\
\hline 10.0 & $\ldots$ & 50 & $\cdots$ & $\cdots$ & . & . & . & 20 & . & $\cdots$ & . & $\cdots$ & 70 \\
\hline 10.5 & . & $3 I$ & $\cdots$ & . & $\cdots$ & $\cdots$ & . & 19 & $\cdots$ & $\cdots$ & . & $\cdots$ & 50 \\
\hline II 0 & $\ldots$ & 35 & $\cdots$ & $\cdots$ & $\ldots$ & $\cdots$ & $\ldots$ & 32 & $\ldots$ & $\cdots$ & . & $\cdots$ & 67 \\
\hline II 5 & $\ldots$ & 38 & $\cdots$ & $\cdots$ & $\cdots$ & $\ldots$ & $\cdots$ & 34 & . & $\cdots$ & . & $\cdots$ & 72 \\
\hline $12 \cdot 0$ & $\cdots$ & 26 & $\cdots$ & $\ldots$ & $\cdots$ & $\cdots$ & . & 30 & $\ddot{0}$ & . & .. & $\cdots$ & 56 \\
\hline I 2.5 & $\cdots$ & 35 & $\cdots$ & $\cdots$ & $\cdots$ & $\cdots$ & . & 33 & 8 & $\cdots$ & . & $\cdots$ & 76 \\
\hline I3.0 & $\ldots$ & 40 & $\ldots$ & . & $\cdots$ & $\cdots$ & $\ldots$ & II & 50 & . & $\ldots$ & . & IOI \\
\hline I 3.5 & $\ldots$ & 24 & 9 & . & . & $\ldots$ & . & 4 & 58 & $\cdots$ & . & . & 95 \\
\hline 14.0 & . & 20 & I6 & .. & $\ldots$ & $\ldots$ & . & $\cdots$ & 65 & 2 & . & . & IO3 \\
\hline I 4.5 & $\ldots$ & I6 & 26 & $\ldots$ & $\ldots$ & . & $\ldots$ & $\ldots$ & 65 & 9 & . & $\ldots$ & II 6 \\
\hline I5.0 & . & 4 & 54 & . & $\ldots$ & $\ldots$ & . & . & 42 & I9 & . & . & II9 \\
\hline 15.5 & .. & I & 57 & . & $\ldots$ & $\ldots$ & . & . & 3 & 56 & 2 & . & II 9 \\
\hline 16.0 & . & $\ldots$ & 74 & I & $\ldots$ & $\cdots$ & . & . & . & I4 & 7 & $\cdots$ & 96 \\
\hline I6.5 & .. & . & 54 & 5 & $\ldots$ & $\cdots$ & . & $\cdots$ & $\cdots$ & 9 & 9 & $\cdots$ & 77 \\
\hline 17.0 & $\ldots$ & . & 40 & II & $\ldots$ & $\cdots$ & . & . & . & $\cdots$ & 9 & $\ldots$ & 60 \\
\hline I7.5 & $\cdots$ & $\ldots$ & I4 & 22 & $\ldots$ & $\ldots$ & $\ldots$ & $\ldots$ & $\ldots$ & $\cdots$ & 2 & 2 & 40 \\
\hline I 8.0 & . & . & 4 & 29 & $\ldots$ & $\cdots$ & . & . & $\cdots$ & $\cdots$ & I & I & 35 \\
\hline I 8.5 & $\ldots$ & $\ldots$ & . & 22 & 4 & $\ldots$ & $\ldots$ & $\ldots$ & . & $\cdots$ & . & I & 27 \\
\hline 19.0 & . & . & . & I4 & 5 & $\cdots$ & . & . & . & . & . & $\ldots$ & I9 \\
\hline 19.5 & . & . & $\cdots$ & 7 & I I & $\cdots$ & $\ldots$ & $\cdots$ & . & $\cdots$ & . & $\cdots$ & I8 \\
\hline $20 \cdot 0$ & $\cdots$ & $\cdots$ & $\cdots$ & . & II & $\cdots$ & . & $\cdots$ & $\ldots$ & . & . & $\cdots$ & II \\
\hline 20.5 & $\cdots$ & . & . & . & IO & $\cdots$ & $\ldots$ & $\ldots$ & . & $\cdots$ & . & $\cdots$ & IO \\
\hline $21 \cdot 0$ & . & . & . & $\ldots$ & 2 & 5 & . & $\cdots$ & . & . & . & $\cdots$ & 7 \\
\hline $2 \mathrm{I} \cdot 5$ & $\cdots$ & $\cdots$ & . & . & I & 3 & $\ldots$ & $\ldots$ & $\cdots$ & . & $\cdots$ & . & 4 \\
\hline $22 \cdot 0$ & $\cdots$ & $\cdots$ & $\cdots$ & . & $\cdots$ & I & . & . & $\cdots$ & $\ldots$ & . & $\cdots$ & I \\
\hline $22 \cdot 5$ & $\cdots$ & $\cdots$ & $\cdots$ & $\cdots$ & $\cdots$ & 2 & $\cdots$ & $\cdots$ & $\cdots$ & $\cdots$ & . & $\cdots$ & 2 \\
\hline Total & I 32 & 403 & 348 & III & 44 & II & 95 & $26 \mathrm{I}$ & $29 I$ & 109 & 30 & 4 & I839 \\
\hline
\end{tabular}


From this table the means of lengths arrived at the end of each year were calculated as with the data of scales and otoliths. These mean lengths are the 'observed lengths' (Table XIX).

Table XiX. 'Observed Lengths', Derived from Grouping the Fish ACCORDING to THE NUMBer OF ANNUAL RINGS IN THE CREST

Length of fish in $\mathrm{cm}$.

At the end
of year
rst
2nd
3 rd
$4^{\text {th }}$

\begin{tabular}{|c|c|c|c|}
\hline \multicolumn{2}{|c|}{ Female } & \multicolumn{2}{|c|}{ Male } \\
\hline Range & Mean & Range & Mean \\
\hline $8 \cdot 5-9 \cdot 0$ & $8 \cdot 75$ & $8 \cdot 5-9 \cdot 0$ & $8 \cdot 75$ \\
\hline $14.0-14.5$ & 14.25 & $12.5-13.0$ & 12.75 \\
\hline $17.0-17.5$ & 17.25 & $15.0-15.5$ & 15.25 \\
\hline $19.0-19.5$ & 19.25 & $16 \cdot 0-16.5$ & 16.25 \\
\hline
\end{tabular}

Working out these means as with otoliths and scales, it is found that the differences between the graphically calculated lengths and the 'observed mean lengths' diminish with age.

The growth of G. minutus diminishes with age. The maximum size to which the fish usually grows is about $22.5 \mathrm{~cm}$. in the female and $19.0 \mathrm{~cm}$. in the male. The maximum age to which the fish generally lives is found to be 5 years. Only four males and eleven females of over 5 years' age have been seen, and so the measurements of their supra-occipital crests give only rough and approximate averages. Because of this the length that the fish reaches at the end of its 5 th year, calculated from the measurements of the crest, is not included in Table XXI. The calculated lengths of the fish at the end of each year have been plotted in Text-fig. I4. It is seen from this that the rate of growth is extremely rapid in the first year. In the 2 nd and 3 rd years the growth diminishes, and it is very little from the 4 th year onwards. The sexes grow at different rates. This is a well known feature in several other fishes, the males growing more slowly than the females. Comparing the growth rate of males with that of the females it is seen that both grow at the same rate and pace in the first year reaching almost the same lengths, viz. 8.2 and $8.3 \mathrm{~cm}$. respectively. Maturity is reached at the beginning of the 2nd year and spawning occurs for the first time in the and year of life. The males grow slower than the females in this 2nd year but the difference in growth is not very marked, the final lengths at the end of the 2nd year being $13.7 \mathrm{~cm}$. in the female and $12.4 \mathrm{~cm}$. in the male. After the spawning the differential growth between the male and the female becomes very marked. Hickling (1933), in Merluccius merluccius, and Hart (1946), in Merluccius hubbsi, have pointed out that the metabolic strain of spawning is greater in mature males than in females. Greater energy is spent in building up the reserves of the reproductive elements than in linear growth in a spent male. This is a very likely cause for the difference in growth rate between the males and females of Gadus minutus after the first spawning in the 2nd year. The diminution in the rate of growth of females 
after the first spawning is also marked, but not to the same extent as in the males. With every succeeding year the growth rate diminishes at such a rate that the males reach the same length in 4 years as the females reach in 3 years.

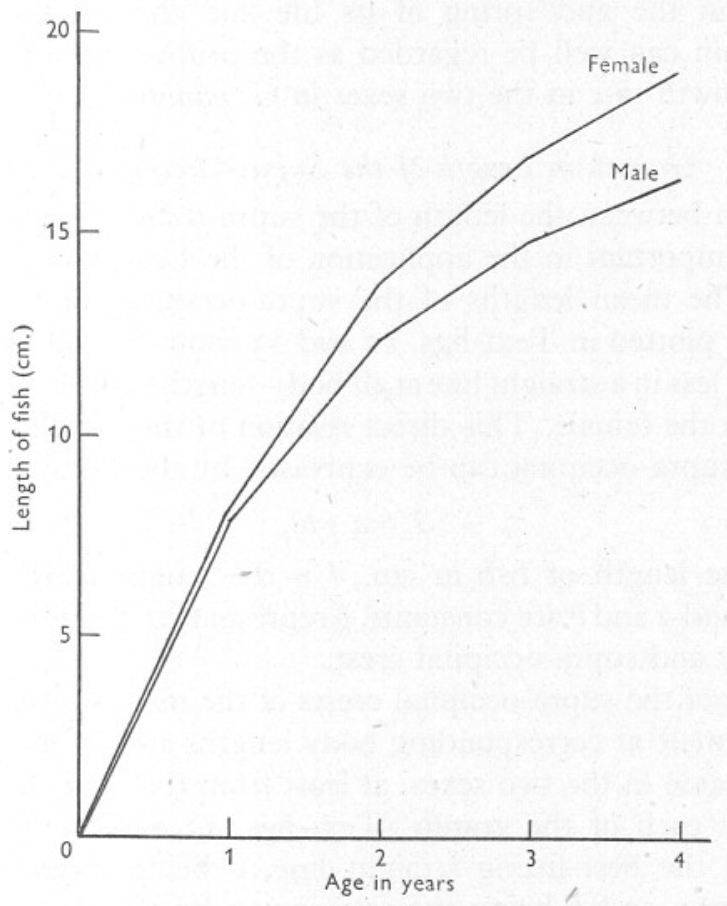

Text-fig. 14. Average growth rate of the male and female G. minutus.

The respective annual increments for each of the first 4 years of life in the male and the female are shown in Table XX.

It is significant that while the growth of females in each year is approximately two-thirds that of the preceding year, the growth in the male is approximately only half that of the preceding year.

Table XX. Annual Growth Increments (CM.) Derived from 'Calculated Lengths'

$\begin{array}{ccc}\text { Year } & \text { Female } & \text { Male } \\ \text { Ist } & 8 \cdot 3 & 8 \cdot 2 \\ \text { 2nd } & 5 \cdot 4 & 4 \cdot 2 \\ \text { 3rd } & 3 \cdot 2 & 2 \cdot 4 \\ \text { 4th } & 2 \cdot 0 & 1 \cdot 6\end{array}$

The comparatively much smaller number of males over 5 year's age in the population analysed can only be due to the reason suggested by Hickling (1933) for the hake. 'In the male hake, it is certainly true that the metabolic strain of the reproduction cycle increases at a very high rate with increase of length and there is no evidence that the male can prolong its life by a slackening off 
of sexual activity.' The facts point rather towards a condition when 'reproduction may eventually overbalance normal metabolism and result in death' (Orton, 1929). The maturity at the beginning of the 2nd year, the occurrence of spawning in the 2nd spring of its life and the consequent differential metabolic strain can well be regarded as the primary factors influencing the differential growth rate in the two sexes in $G$. minutus.

\section{Growth in Length of the Supra-Occipital Crest}

The relation between the length of the supra-occipital crest and the length of the fish is important in the application of the Lea-Dahl formula for backcalculation. The mean lengths of the supra-occipital crests at the different lengths of fish plotted in Text-figs. I2 and I3 show that all the points in each sex lie more or less in a straight line at all body-lengths above $7.0 \mathrm{~cm}$. in the male and $9.0 \mathrm{~cm}$. in the female. This direct relation of the length of the fish to the length of the supra-occipital can be expressed by the formula

$$
L=a+b l,
$$

where $L$ is the length of fish in $\mathrm{cm}$., $l$ is the length of the supra-occipital crest in mm., and $a$ and $b$ are constants, $b$ representing the ratio of increments of length of body and supra-occipital crest.

The lengths of the supra-occipital crests of the male are slightly lower than those of the female at corresponding body lengths and so the constants $a$ and $b$ are not the same in the two sexes, at least from the time they are beginning to mature. In each of the graphs (Text-figs. I2 and I3) the constants are obtained from the best-fitting straight line, $a$ being given by the value of $L$ when $l$ is zero, and $b$ being the ratio given by the slope of the line (the tangent of its angle to the vertical).

Interpolating the values of the constants in the formula for $G$. minutus, it becomes

$$
\text { and } \quad \begin{aligned}
& L=3 \cdot 18+\mathrm{I} \cdot 57 l \\
& L=2 \cdot 10+\mathrm{I} \cdot 82 l
\end{aligned}
$$

Using these formulae it is possible to back-calculate the lengths of fish at any particular length of the supra-occipital crest. Conversely the theoretical lengths of the supra-occipital crests at any particular body-length also can be calculated. The theoretical lengths of the supra-occipital crests calculated by means of these formulae are given in Table XV (p. 220).

It is found that the back-calculated lengths of fish estimated by these formulae differ from the actual observed lengths only by $0 . \mathrm{I}-0.5 \mathrm{~cm}$.

It would appear from the formula $L=a+b l$ that the value of ' $a$ ' is the length of fish at which the supra-occipital crest begins to develop. If so the crest ought to develop at $2 \cdot \mathrm{I} \mathrm{cm}$. But actually the supra-occipital crest is first observed when the fish is $\mathrm{I} \cdot \mathrm{I} \mathrm{cm}$. long (it appears as a very narrow and small streak on the dorsal aspect of the neurocranium). If this 'presupraoccipital 
fish length' of $\mathrm{I} \cdot \mathrm{I} \mathrm{cm}$. is applied to the orthodox Lea-Dahl formula it is possible to back-calculate body-lengths from the formula

$$
L_{r}=\frac{L_{R}}{l_{R}} l_{r}+\mathrm{I} \cdot \mathrm{I},
$$

where $L_{r}$ and $L_{R}$ are two different body-lengths, with $l_{r}$ and $l_{R}$ their corresponding crest-lengths. The ratio $L_{R} / l_{R}$ has been found empirically, $l_{r}$ is any chosen crest-length, and $L_{r}$ the body-length which is to be calculated. The modified Lea-Dahl formula differs from that used above (viz. $L=a+b l$ ) in having a smaller value for ' $a$ ' and in using an empirical ratio which tends to be greater than ' $b$ '. The lengths back-calculated by the modified Lea-Dahl formula usually differ from the actual observed lengths by 0.1 to $0.9 \mathrm{~cm}$, and, except for the smallest immature fish, the formula seems to have no particular merit.

\section{Comparison between the Growth Rate Determined by Supra-Occipital Crest, Scales, Otoliths and Petersen Method}

The length of the fish at the end of the respective years of its life history arrived at by examination of the scales, otoliths, supra-occipital crests and the size analysis are now compared (Table XXI). The data of the lengths calculated from the supra-occipital crests are given in two ways-one showing the lengths calculated by the graphical method, and the other calculated by the Lea-Dahl formula.

\section{Table XXI. Calculated Lengths in cm. of Gadus minutus}

\begin{tabular}{|c|c|c|c|c|c|}
\hline \multirow{2}{*}{$\underset{\text { (years) }}{\text { Age }}$} & \multirow{2}{*}{$\begin{array}{l}\text { From } \\
\text { scales }\end{array}$} & \multirow{2}{*}{$\begin{array}{c}\text { From } \\
\text { otoliths }\end{array}$} & \multicolumn{2}{|c|}{ From supra-occipital } & \multirow{2}{*}{$\begin{array}{c}\text { From } \\
\text { size } \\
\text { analysis }\end{array}$} \\
\hline & & & Graphical & L-D formula & \\
\hline & \multicolumn{5}{|c|}{ Female } \\
\hline I & $8 \cdot 75$ & $9 \cdot 75$ & $8 \cdot 3$ & $7 \cdot 7$ & $8 \cdot 0$ \\
\hline 2 & 14.25 & 14.75 & 13.7 & 13.5 & I4.0 \\
\hline 3 & $17 \cdot 25$ & $17 \cdot 75$ & I6.9 & $17 \cdot 4$ & $17 \cdot 0$ \\
\hline 4 & $19 \cdot 75$ & 19.25 & $19 \cdot 0$ & 19.0 & $\therefore$ \\
\hline \multicolumn{6}{|c|}{ Male } \\
\hline I & $8 \cdot 75$ & $9 \cdot 75$ & $8 \cdot 2$ & $8 \cdot 0$ & $8 \cdot 0$ \\
\hline 2 & $12 \cdot 75$ & 13.25 & $12 \cdot 4$ & $12 \cdot 5$ & $13 \cdot 0$ \\
\hline 3 & $15 \cdot 25$ & $15 \cdot 75$ & 14.8 & $15 \cdot 4$ & 15.0 \\
\hline 4 & 16.75 & $17 \cdot 25$ & I6.4 & 16.4 & $\therefore$ \\
\hline
\end{tabular}

In the back-calculation by the Lea-Dahl formula all the lengths have been calculated from the fish length and supra-occipital length of the fish at the end of the 4th year. All these lengths are standard lengths. The values arrived at by using the supra-occipital measurements are nearest to the actual observed lengths found in the size analysis. The lengths derived by examination of the otoliths and scales are higher than the empirical lengths. The differences between the lengths calculated by the graphical method and those by the Lea-Dahl formula are only $0.2-0.6 \mathrm{~cm}$., which are unimportant in adults. 
These calculated lengths and the age and growth rate of female G. minutus calculated from supra-occipital crests compare quite well with the findings of Stuart Thomson (1904), allowing for certain personal errors. Cunningham (I89I) made some interesting observations on the growth rate of G. minutus by size analysis. The measurements and other details given by him are quoted in Table XXII.

Cunningham states that the more than 200 specimens less than 3 in. in length collected from Whitsand Bay 'are undoubtedly from the ova shed the preceding spring....It is also clear that the specimens of $4 \cdot 5-6 \cdot 4$ in. obtained on 9 July I89I near the Eddystone were in their second year.' As growth rate decreases gradually, he regarded specimens of April I89I to be 2 years of age.

Table XXII. Summary of CunNingham's ObSeRvations on GADUS MINUTUS

\begin{tabular}{|c|c|c|c|c|}
\hline Date & $\begin{array}{l}\text { Length } \\
\text { in } \mathrm{cm} \text {. }\end{array}$ & $\begin{array}{l}\text { Length } \\
\text { in in. }\end{array}$ & Calculated age & Place of capture \\
\hline May 1890 & $2 \cdot 8-4 \cdot 3$ & $\mathrm{I} \cdot \mathrm{I}-\mathrm{I} \cdot 7$ & $8-\mathrm{I} 2$ weeks & Cattewater \\
\hline June I89I & $4 \cdot 2-7 \cdot 2$ & $I \cdot 6-2 \cdot 9$ & About 3 months & Whitsand Bay \\
\hline July $189 \mathrm{I}$ & II $\cdot 5-16 \cdot 2$ & $4 \cdot 5-6 \cdot 4$ & I year and 3 months & North of Eddystone \\
\hline April I89I & $14 \cdot 3-19 \cdot 0$ & $5 \cdot 6-7 \cdot 5$ & 2 years & East of Eddystone \\
\hline June 1889 & $\left\{\begin{array}{c}13.7-15.0 \\
20 \cdot 0\end{array}\right.$ & $5 \cdot 4-5 \cdot 8$ & $\begin{array}{l}\text { I year and } 2 \text { months } \\
2 \text { years and } 2 \text { months }\end{array}$ & $\begin{array}{l}\text { Whitsand Bay } \\
\text { Whitsand Bay }\end{array}$ \\
\hline
\end{tabular}

Cunningham's estimation of the length reached in the Ist year coincides fairly well with the present findings. His consideration of the $14 \cdot 3-20 \mathrm{~cm}$. lengthgroup as belonging to one and the same age group, viz. past 2 years, is incorrect. That length group is really composed of two or even three age classes. The treatment of the data irrespective of sex also has contributed to the mixing of the different year classes.

\section{The Relation Between the Length and Weight of Gadus minutus and its Value as an Index of the Spawning Season}

Hickling (1930, 1940) and Hart (1946) have shown how the analysis of the weights of fish may yield interesting results from which important conclusions can be drawn. All the G. minutus were weighed in a Salter spring balance to the nearest gram. These weights were treated separately for each $\mathrm{cm}$. length group and month in either sex. From the weights of several specimens of a $\mathrm{cm}$. length group, the average weight for that particular length group was worked for each month. These average weights were used for computing the ponderal index for separate $\mathrm{cm}$. length-groups of either sex. The ponderal index was worked out from the formula used both by Hickling (1930) and Hart (1946), viz.:

$$
K=\frac{W}{L^{3}} \times 100,
$$

where $W$ is the average weight of fish in gm., $L$ is the mean length of fish in $\mathrm{cm}$. and $K$ is the ponderal index to be calculated. With suitable precautions 
the ponderal index can often be taken as a measure of the fish's condition, and in these circumstances can appropriately be termed 'condition factor'.

Ponderal indices have been computed in three ways:

(i) Ponderal index for each mean $\mathrm{cm}$. length group for each month in either sex.

(ii) The average ponderal index for each $\mathrm{cm}$. length group of either sex for the whole year.

(iii) The average ponderal index of the whole sample of fish of either sex in every month.

Hart (I946) has stated that the $K$ values may give a very good idea of the broad outline of the seasonal cycle for the species. He observed that 'apart from the seasonal variation in condition there is a secondary variation related to the length of the fish'. With increase in age 'there is a lower level of condition throughout the seasonal cycle consequent upon the increased metabolic strain of spawning. The point of inflexion on a curve showing this diminution of $K$ with increasing length is thus a good indication of the length at which sexual maturity is attained.' In a growing organism a progressive variation of the ponderal index can be due to allometric growth. This point has been borne in mind when using the ponderal index variation of the G. minutus as an indicator of the spawning period.

The average values of $K$ in relation to the length of the fish of either sex are given below (Table XXIII).

\begin{tabular}{|c|c|c|c|c|}
\hline \multirow[b]{2}{*}{$\begin{array}{l}\text { Mean length of } \\
\text { fish in } \mathrm{cm} .\end{array}$} & & LE XX & \multicolumn{2}{|c|}{ Male } \\
\hline & $\begin{array}{c}\text { No. of } \\
\text { specimens }\end{array}$ & K & $\begin{array}{c}\text { No. of } \\
\text { specimens }\end{array}$ & $K$ \\
\hline 7 & II 6 & I. 224 & 23 & I. 224 \\
\hline 8 & 167 & $1.270^{\circ}$ & 147 & $\mathrm{I} \cdot 282$ \\
\hline 9 & I40 & $\mathrm{I} \cdot 235$ & 120 & $I \cdot 27 I$ \\
\hline I0 & II3 & 1.250 & 72 & 1.280 \\
\hline I I & 72 & I. 297 & 58 & I. 347 \\
\hline 12 & 90 & 1.383 & IO4 & $\mathrm{I} \cdot 320$ \\
\hline I3 & I92 & I. 448 & 407 & $\mathrm{I} \cdot 272$ \\
\hline 14 & 465 & 1.402 & 344 & $\mathrm{I} \cdot 266$ \\
\hline I5 & 453 & $\mathrm{I} \cdot 356$ & 334 & $\mathrm{I} \cdot 253$ \\
\hline 16 & $49 \mathrm{I}$ & 1.322 & IO3 & I. 275 \\
\hline I7 & 504 & I. 299 & 47 & $\begin{array}{l}1.225 \\
\end{array}$ \\
\hline 18 & 248 & $\mathrm{I} \cdot 273$ & $\begin{array}{r}41 \\
4\end{array}$ & $\begin{array}{l}1 \cdot 209 \\
\end{array}$ \\
\hline 19 & $\mathrm{I} 4 \mathrm{I}$ & I.263 & 2 & $\mathrm{I} \cdot 2 \mathrm{I} 4$ \\
\hline 20 & 34 & $\mathrm{I} \cdot 224$ & .. & .. \\
\hline $2 \mathrm{I}$ & II & I.23I & .. & .. \\
\hline & I & 1.018 & .. & .. \\
\hline 23 & 2 & 0.789 & .. & .. \\
\hline
\end{tabular}

These average values of $K$ in relation to the length of fish of either sex have been plotted as two curves in Text-fig. I5.

From the above graph it is seen that the $K$ value is low in the very small length groups and gradually builds up until it falls in the greater length groups. If the point of inflexion of these curves is to be taken as an index of the length 
at first spawning, it is found that the males mature at an average length of II $\mathrm{cm}$. and the females at an average length of $I_{3} \mathrm{~cm}$. The $K$ values of males are higher than those of the females of corresponding lengths before maturity. The $K$ values of mature and post-mature males are lower than those of the females of corresponding lengths. This agrees with the observations of Hickling (1930) on the European hake and Hart (1946) on the Patagonian hake. These low values of $K$ for the mature and post-mature males have been explained by Hickling (1930) as due to 'the very rapidly increasing metabolic strain of spawning in the older males'. From direct observation it has been

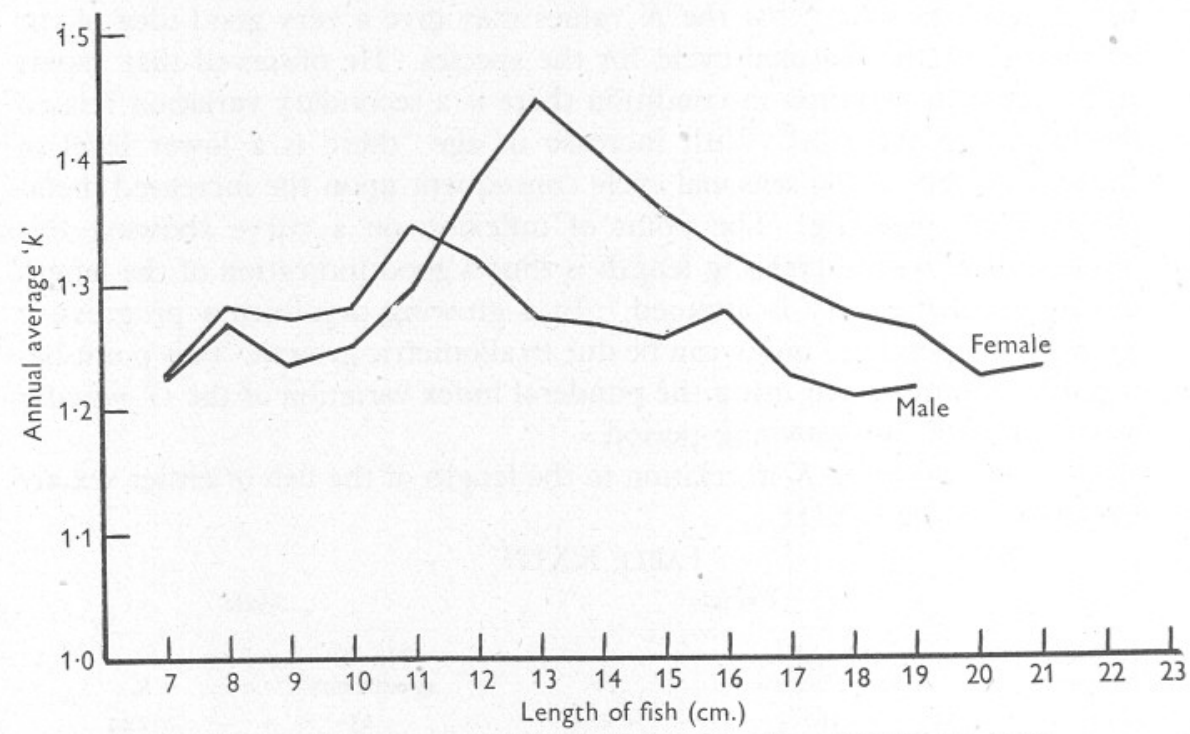

Text-fig. I5. The average $K$ at the different lengths of fish in the male and female $G$. minutus.

noticed that the majority of males below II cm. and the majority of females below $13 \mathrm{~cm}$. are immature; but observations on the actual gonadial changes could not be carried out in detail. In general, however, the deduction seems fairly substantiated that the average male matures at II cm. and the average female at $13 \mathrm{~cm}$. Maturity is thus attained when the fish is in its 2nd year of life. The early maturity in contrast to the long adolescence of so many other larger gadoids is presumably due to the shorter span of life of G. minutus.

The length at which the fish matures now having been fixed, data from the $K$ values have been selected to examine the seasonal variation of the ponderal index of each length group of either sex. These monthly variations of $K$ are given in Table XXIV.

The variation of $K$ values indicates the spawning period of the fish. The decline in the values denotes the beginning of the spawning in the species, since this downward trend is assumed to be consequent upon the lower level 
Table XXIV. Table Showing the Ponderal Index $K$ for the Individual Length Groups in the Different Months

Length in $\mathrm{cm}$.

\begin{tabular}{|c|c|c|c|c|c|c|c|c|c|c|c|c|c|c|c|c|c|c|}
\hline Year & Month & 7 & 8 & 9 & IO & II & 12 & I3 & I4 & I5 & I6 & I7 & I8 & I9 & 20 & 21 & 22 & 23 \\
\hline \multicolumn{19}{|c|}{ Female } \\
\hline \multirow[t]{8}{*}{ I948 } & May & $\cdots$ & $\cdots$ & .. & $\cdots$ & $I \cdot 248$ & I.393 & $\mathrm{I} \cdot 488$ & $\mathrm{I} \cdot \mathrm{I} 85$ & $I \cdot 233$ & $I \cdot 22 I$ & I.079 & $I \cdot 235$ & $I \cdot 283$ & $\cdots$ & $\cdots$ & $\cdots$ & $\cdots$ \\
\hline & June & . & . & . & . & $I \cdot 254$ & $I \cdot 4 \mathrm{IO}$ & $I \cdot 639$ & I.294 & $I \cdot 252$ & $I \cdot 367$ & $1 \cdot 303$ & $I \cdot 235$ & $I \cdot 370$ & 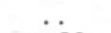 & $\ldots$ & .. & .. \\
\hline & July & . & . & .. & .. & . & $\cdots$ & $I \cdot 684$ & 1.603 & I.5II & $I \cdot 489$ & $I \cdot 434$ & $I \cdot 285$ & $I \cdot 3 I 2$ & $I \cdot I 88$ & $(I \cdot 296)$ & . & . \\
\hline & Aug. & . & . & $\cdots$ & $\cdots$ & .. & $(I \cdot 447)$ & $I \cdot 442$ & $I \cdot 567$ & $I \cdot 48 I$ & $I \cdot 318$ & $I \cdot 425$ & $I \cdot 344$ & $I \cdot 283$ & I. 338 & $(I \cdot 339)$ & $\cdots$ & . \\
\hline & Sept. & 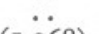 & $\cdots$ & $\cdots$ & 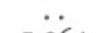 & . & $\therefore$ & $(I \cdot 43 I)$ & $I \cdot 385$ & $I \cdot 363$ & I. 294 & $1 \cdot 303$ & $I \cdot 372$ & $I \cdot 3 I 2$ & . & 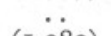 & $\cdots$ & .. \\
\hline & Oct. & $(\mathrm{I} \cdot 268)$ & $(I \cdot 290)$ & $(I \cdot 235)$ & $I \cdot 264$ & .. & . & $I \cdot 468$ & I.585 & $I \cdot 463$ & I. 416 & $I \cdot 343$ & $I \cdot 269$ & I. 327 & . & $(\mathrm{I} \cdot 080)$ & . & . \\
\hline & $\begin{array}{l}\text { Nov. } \\
\text { Dec }\end{array}$ & $1 \cdot 215$ & $I \cdot 272$ & I.255 & $\mathrm{I} \cdot 28 \mathrm{I}$ & $\cdots$ & . & $\cdots$ & $\mathrm{I} \cdot 603$ & $I \cdot 523$ & I. 440 & $I \cdot 323$ & $I \cdot 235$ & $I \cdot 356$ & $\because 8$ & $\ddot{x}$ & $\cdots$ & $\cdots$ \\
\hline & Dec. & $\cdots$ & $\cdots$ & $\cdots$ & $\cdots$ & $\cdots$ & $\cdots$ & $\cdots$ & I.54I & $I \cdot 492$ & I.4I6 & $I \cdot 364$ & $I \cdot 252$ & I.254 & $\mathrm{I} \cdot \mathrm{I} 88$ & $I \cdot 209$ & $\cdots$ & $\cdots$ \\
\hline \multirow[t]{5}{*}{ I949 } & & $\ddot{8}$ & $I \cdot 276$ & $(I \cdot 246)$ & $I \cdot 24 I$ & $(\mathrm{I} \cdot 325)$ & $I \cdot 33 I$ & I.488 & I.505 & $I \cdot 5 I 4$ & $\mathrm{I} \cdot 392$ & $I \cdot 364$ & $I \cdot 372$ & $\cdots$ & 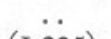 & . & . & $\cdots$ \\
\hline & $\begin{array}{l}\text { Feb. } \\
\text { Mar. }\end{array}$ & $\mathbf{I} \cdot \mathbf{I} 89$ & $I \cdot 260$ & $I \cdot 22 I$ & I.23I & I.254 & $(I \cdot 403)$ & $(I \cdot 332)$ & I.348 & $I \cdot 3 I 4$ & I.270 & I.3I 2 & I.303 & $I \cdot 196$ & $(I \cdot 325)$ & . & . & $\cdots$ \\
\hline & Apr. & 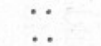 & $\begin{array}{c}I \cdot 242 \\
\ldots\end{array}$ & $\begin{array}{l}1.214 \\
(1 \cdot 239)\end{array}$ & $\begin{array}{l}\mathrm{I} \cdot 224 \\
\mathrm{I} \cdot 259\end{array}$ & $\begin{array}{c}(I \cdot 25 I) \\
I \cdot 25 I\end{array}$ & $\begin{array}{c}(I \cdot 33 I) \\
I \cdot 373\end{array}$ & $\begin{array}{l}I \cdot 304 \\
I \cdot 304\end{array}$ & $\begin{array}{l}\mathrm{I} \cdot 276 \\
\mathrm{I} \cdot \mathrm{I} 30\end{array}$ & $\begin{array}{l}I \cdot I 85 \\
I \cdot I 26\end{array}$ & $\begin{array}{l}I \cdot 270 \\
I \cdot I I 8\end{array}$ & $\begin{array}{l}I \cdot 282 \\
I \cdot 229\end{array}$ & $\begin{array}{l}I \cdot 303 \\
I \cdot I 43\end{array}$ & $\begin{array}{l}I \cdot I 66 \\
I \cdot I O I\end{array}$ & (I) & $\cdots$ & $\cdots$ & $(0.789)$ \\
\hline & May & $\ldots$ & $I \cdot 246$ & $I \cdot 224$ & $\mathrm{I} \cdot 234$ & $\mathrm{I} \cdot 387$ & $\mathrm{I} \cdot 366$ & $\mathrm{I} \cdot 370$ & $\mathrm{I} \cdot 228$ & $I \cdot 252$ & $I \cdot 200$ & $\mathrm{I} \cdot \mathrm{I} 3 \mathrm{I}$ & $\mathrm{I} \cdot 2 \mathrm{I} 2$ & $\mathrm{I} \cdot \mathrm{I} 96$ & $\begin{array}{l}(1.125) \\
I \cdot 180\end{array}$ & $\begin{array}{l}\cdots \\
\cdots\end{array}$ & . & $\begin{array}{c}(0709) \\
\ldots\end{array}$ \\
\hline & June & . & I. 294 & I. 246 & $I \cdot 266$ & $\mathrm{I} \cdot 34 \mathrm{I}$ & I. 392 & $I \cdot 424$ & $\mathrm{I} \cdot 284$ & $I \cdot 272$ & I. 298 & $I \cdot 222$ & $I \cdot 262$ & .. & .. & $\ldots$ & $\ldots$ & . \\
\hline & \multicolumn{18}{|c|}{ Male } \\
\hline \multirow[t]{7}{*}{ I948 } & May & . & $\cdots$ & . & . & I.297 & $I \cdot 33 I$ & $I \cdot 286$ & $I \cdot 276$ & $I \cdot 22 I$ & $I \cdot 22 I$ & . & .. & . & & & & \\
\hline & June & . & .. & .. & .. & $I \cdot 317$ & $I \cdot 465$ & $I \cdot 350$ & $I \cdot 309$ & $I \cdot 294$ & I. 468 & $I \cdot 29 I$ & . & . & • & & & \\
\hline & July & $\cdots$ & .. & .. & . & . & $I \cdot 40 I$ & $I \cdot 3 I 4$ & $I \cdot 3 I 2$ & $I \cdot 310$ & I. 492 & $I \cdot 253$ & . & . & & & & \\
\hline & Aug. & $\cdots$ & $\cdots$ & $\cdots$ & . & . & $(I \cdot 33 I)$ & $(\mathrm{I} \cdot 26 \mathrm{I})$ & $I \cdot 290$ & $I \cdot 27 I$ & $I \cdot 22 I$ & $(\mathrm{I} \cdot 22 \mathrm{I})$ & $(\mathrm{I} \cdot 2 \mathrm{I} 7)$ & $(\mathrm{I} \cdot 2 \mathrm{I} 8)$ & & & & \\
\hline & Sept. & $\because$ & & $(\mathrm{I} \cdot \overrightarrow{254})$ & $(1 \cdot 270)$ & 북 & . & $I \cdot 257$ & I. 265 & $I \cdot 256$ & $I \cdot 23 I$ & $I \cdot 2 I 4$ & $(I \cdot 200)$ & $\cdots$ & & & & \\
\hline & $\begin{array}{l}\text { Oct. } \\
\text { Nov }\end{array}$ & $\begin{array}{r}\ddot{3} 32 \\
\end{array}$ & $I \cdot \ddot{29 I}$ & $\begin{array}{l}(I \cdot 254) \\
(I \cdot 282)\end{array}$ & $\begin{array}{c}(1 \cdot 270) \\
\ldots\end{array}$ & $(\mathrm{I} \cdot 372)$ & . & I. 268 & $(1 \cdot 276)$ & $I \cdot 268$ & $\mathrm{I} \cdot 25 \mathrm{I}$ & $I \cdot 22 I$ & . & $(\mathrm{I} \cdot 2 \mathrm{IO})$ & & & & \\
\hline & $\begin{array}{l}\text { Nov. } \\
\text { Dec. }\end{array}$ & $\begin{array}{c}1.332 \\
\ldots\end{array}$ & . & $\ldots$ & .. & $\begin{array}{c}(I \cdot 380) \\
\ldots\end{array}$ & . & $\begin{array}{l}I \cdot 26 I \\
I \cdot 272\end{array}$ & $\begin{array}{l}I \cdot 285 \\
I \cdot 27 I\end{array}$ & $\begin{array}{l}I \cdot 276 \\
I \cdot 288\end{array}$ & $\begin{array}{c}\mathrm{I} \cdot 25^{8} \\
. .\end{array}$ & $\cdots$ & . & $\cdots$ & & & & \\
\hline \multirow[t]{6}{*}{ I949 } & Jan. & . & .. & $(I \cdot 242)$ & $I \cdot 290$ & $(\mathrm{I} \cdot 325)$ & $(\mathrm{I} \cdot 242)$ & $I \cdot 264$ & $I \cdot 284$ & $I \cdot 299$ & $I \cdot 37 I$ & $\cdots$ & $\cdots$ & $\cdots$ & & & & \\
\hline & Feb. & $I \cdot I I 6$ & $I \cdot 242$ & $I \cdot 235$ & $I \cdot 280$ & $I \cdot 360$ & $I \cdot 23 I$ & I. 239 & $I \cdot 22 I$ & $I \cdot 215$ & $(\mathrm{I} \cdot 2 \mathrm{OI})$ & $\cdots$ & $\cdots$ & $\cdots$ & & & & \\
\hline & Mar. & .. & $I \cdot 264$ & $I \cdot 228$ & $I \cdot 290$ & $I \cdot 346$ & $I \cdot 209$ & $\mathrm{I} \cdot 2 \mathrm{I} 4$ & $I \cdot 203$ & $I \cdot 165$ & $I \cdot I 70$ & . & .. & . & & & & \\
\hline & Apr. & . & . & $(\mathrm{I} \cdot 2 \mathrm{I} 2)$ & $I \cdot 224$ & (I·209) & I. I99 & $I \cdot I 63$ & $I \cdot 186$ & $I \cdot 156$ & $(I \cdot I 47)$ & I. I I 8 & .. & .. & & & & \\
\hline & May & . & $I \cdot 329$ & $I \cdot 317$ & $(I \cdot 292)$ & . & I. 339 & $I \cdot 292$ & $I \cdot 260$ & $I \cdot 240$ & $(\mathrm{I} \cdot 228)$ & $I \cdot 26 I$ & $\ldots$ & $\ldots$ & & & & \\
\hline & June & . & .. & .. & $I \cdot 302$ & $I \cdot 368$ & I. 435 & $I \cdot 312$ & $I \cdot 286$ & $I \cdot 283$ & $(I \cdot 3 I 4)$ & $\cdots$ & .. & .. & & & & \\
\hline
\end{tabular}

The numbers of individuals on which the above figures are based may be ascertained from Tables XII and XIII.

The figures in brackets are based on 3 or less than 3 individuals. 
of condition 'due to the increased metabolic strain'. The decline occurs after January and the mean $K$ values remain low till May. This indicates that the spawning period of the fish is between February and May. The lowest level of condition is in March-April when the spawning is at its height. This observation agrees well with Cunningham's (I89I) assumption, in his computation of the growth rate of the fish, that the annual life cycle of $G$. minutus begins in April. In June and July there is a rapid recovery and increase of $K$ in both sexes. There is a minor drop in August and September, but this drop is much smaller than that observed during the spawning months. In the analysis of the food of $G$. minutus three periods had been distinguished in the annual life cycle of the fish according to their feeding activity; viz. a period of low feeding synchronizing with the months of spawning, a period of active feeding during the months immediately following the spawning, when the fish is recuperating from the strain of spawning, and a period of 'average feeding' when the fish is growing. During the period of low feeding the $K$ value is very low, and during the period of active feeding there is a sudden increase in the $K$ values. The $K$ values show a fluctuation during the period of average feeding when the fish is growing. At the beginning of this period, i.e. in August and September, there is a minor drop in the condition factor. It is possible that the metabolic changes in the fish at this period tend more towards an increase in linear dimensions than the building up of weight, a process which would automatically reduce the condition factor.

There is a differential seasonal variation of $K$ values between the various year-groups which is quite suggestive. The males and females of the lengthgroup I2-I6 cm. show a bigger seasonal variation than the others. Hart (I946) also observed a similar differential variation in Merluccius hubbsi. He explained the anomaly as due to inadequate sampling. Selective sampling may have contributed to the differential variation in Gadus minutus also to some extent, but the length-group I2-I6 cm. consists of I, II and III groups of males and I and II groups of females, and are mostly spawners for the first and second time. It is probable that the earliest spawnings in the life history of such a short-lived fish are the most important in contributing to a potential increase and stabilization of the population (i.e. contribute a relatively larger bulk of reproductive products), and this may be one of the major causes for the differential variation of $K$ values between particular length-groups.

There is no evidence from ponderal index variation or direct observation to suggest that the older age-groups spawn earlier than the younger. The spawning periods in all the groups synchronize. There is no shoreward movement of the older and larger groups occurring earlier than the smaller ones similar to the movements observed by Hickling (1930) in Merluccius merluccius and Hart (1946) in M. hubbsi. Unlike the long-lived hake, the poor-cod is not an off-shore fish and its total span of life is small. Its distribution is limited within the $200 \mathrm{~m}$. contour, and the population here studied was sampled only 
within some 15 miles of the coast, so that any possible migration towards shallower regions is scarcely apparent.

The males in general show a lower $K$ value throughout the spawning and growing periods than do the females. This agrees with Hickling's (I930)

Table XXV. Ponderal Index $K$ for the Whole Sample in each Month

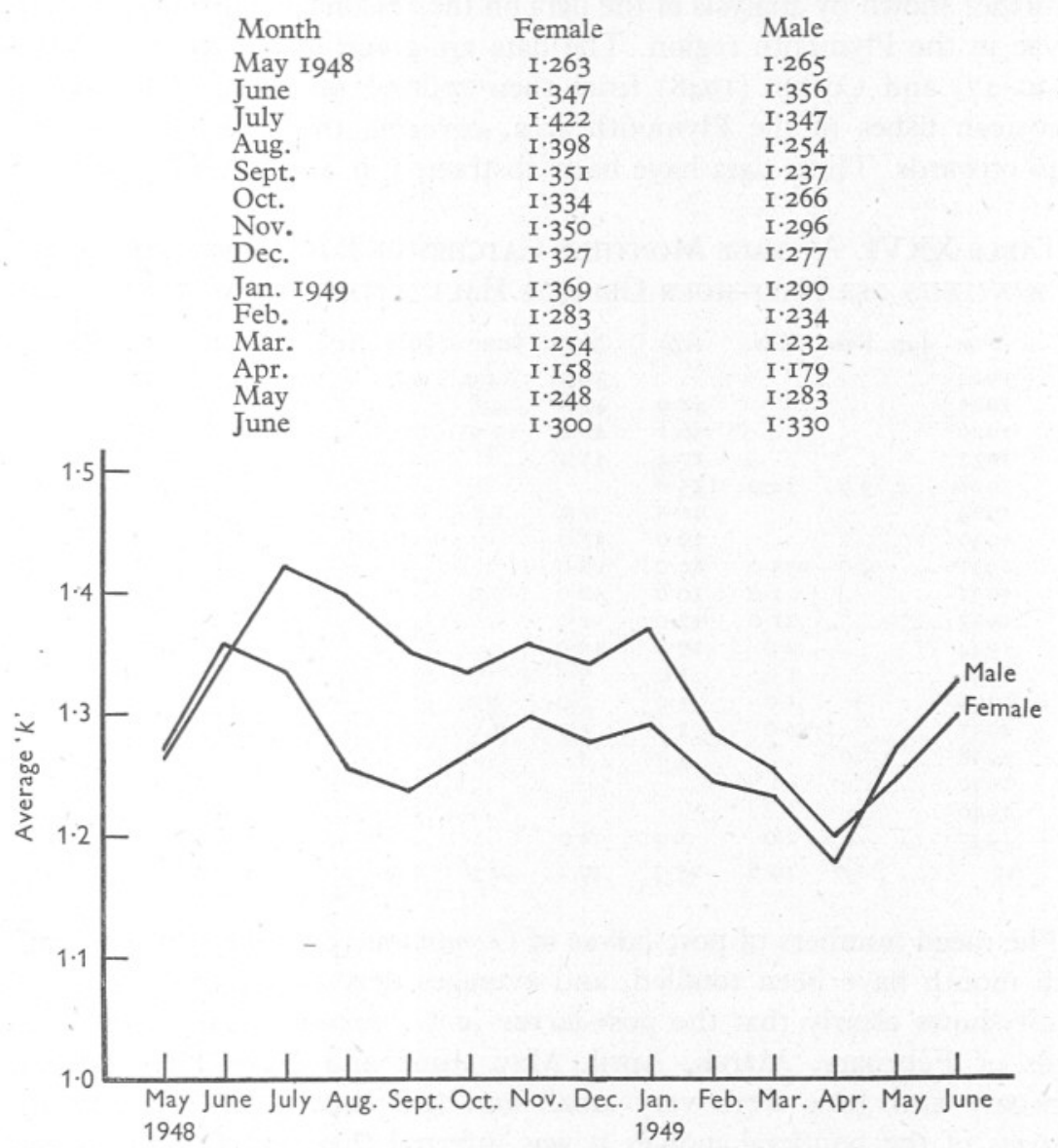

Text-fig. 16. The mean $K$ values for the whole sample of fish in successive months.

observation that the metabolic strain of spawning is greater in males than in females; but the recovery from the metabolic stress appears to be more rapid in the male than in the female when spawning is over.

The average ponderal index has also been calculated for the whole sample of fish of either sex in each month to examine whether by treating the data from bulk sample there is any marked departure from the observations on individual length groups. These monthly averages are given in Table XXV.

These values have been plotted as two curves in Text-fig 16 , which indicates 
the same trend of events as deduced from the variations in condition of individual length-groups. The spawning period is clearly defined as between February and May and the recovery of males after spawning is more rapid than that of the females.

That the main spawning period of Gadus minutus is from February to May is further shown by analysis of the data on the seasonal occurrence of the postlarvae in the Plymouth region. The data are given in the records of Russell (I930-47) and Corbin (1948) from their routine sampling of the young of teleostean fishes in the Plymouth area, covering the periods I924-39, and I946 onwards. These data have been abstracted in Table XXVI.

\section{Table XXVI. Average Monthly Catches of Post-Larvae of Gadus minUtus Per Half-hour Oblique HaUl with the $2 \mathrm{M}$. Ring Trawl}

\begin{tabular}{|c|c|c|c|c|c|c|c|c|c|c|c|c|}
\hline Year & Jar & Feb. & Mar. & Apr. & May & June & July & Aug & Sep & $\mathrm{Oct}$ & Nor & Dec \\
\hline I924 & & & & & 33.9 & 24.9 & $4 \cdot 2$ & & & & & \\
\hline I925 & & & & $42 \cdot 9$ & 49 & $4^{\circ}$ & . & . & & & & \\
\hline I926 & & & & $56 \cdot I$ & $40 \cdot 2$ & I2.9 & $\cdots$ & .. & $\cdots$ & & & \\
\hline $\begin{array}{l}\text { I927 } \\
\text { I } 928\end{array}$ & $\ldots$ & 3.9 & $24 \cdot 0$ & $\begin{array}{r}17 \cdot 4 \\
135.6\end{array}$ & $43 \cdot 2$ & . & . & . & $\cdots$ & $\cdots$ & $\cdots$ & $\cdots$ \\
\hline I929 & & & & 10.5 & 0.9 & $I \cdot 2$ & 0.3 & $\cdots$ & $\cdots$ & $\cdots$ & & \\
\hline I930 & & . & .. & 19.0 & 37.0 & + & $\cdots$ & $\cdots$ & $\cdots$ & . & $\cdots$ & $\cdots$ \\
\hline I93I & $\cdots$ & $9 \cdot 0$ & I $75^{\circ} \mathrm{O}$ & $80 \cdot 0$ & 18.0 & . & .. & $\cdots$ & $\cdots$ & $\cdots$ & . & . \\
\hline I932 & $\ldots$ & . & $I \cdot O$ & 10.0 & $52 \cdot 0$ & $I \cdot O$ & . & . & $\cdots$ & $\cdots$ & . & $\therefore$ \\
\hline I933 & $\cdots$ & $\cdots$ & $2 \mathrm{I} \cdot 0$ & 12.0 & 1.0 & . & $\cdots$ & $\cdots$ & $\cdots$ & $\cdots$ & $\cdots$ & . \\
\hline I934 & $\cdots$ & . & $2 \cdot 0$ & 17.0 & I9.0 & $\cdots$ & $\cdots$ & . & $\cdots$ & $\cdots$ & $\cdots$ & . \\
\hline I935 & $\cdots$ & $\cdots$ & $I \cdot O$ & $\mathrm{I} \cdot \mathrm{O}$ & 5.0 & $\therefore$ & $\cdots$ & $\cdots$ & $\cdots$ & $\cdots$ & $\cdots$ & - \\
\hline I936 & . & + & $I \cdot O$ & $I \cdot O$ & I.O & 4.0 & $\because$ & $\cdots$ & $\cdots$ & $\cdots$ & $\cdots$ & - \\
\hline I937 & $\cdots$ & . & 10.0 & $2 \cdot 0$ & $I \cdot O$ & $1 \cdot 0$ & + & $\cdots$ & $\cdots$ & $\cdots$ & $\cdots$ & . \\
\hline I938 & . & $7 \cdot 0$ & $\cdots$ & 5.0 & + & . & . & $\cdots$ & $\cdots$ & $\cdots$ & $\cdots$ & . \\
\hline I939 & $\cdots$ & . & $\cdots$ & $\cdots$ & + & . & $\ddot{0}$ & $\cdots$ & $\cdots$ & $\cdots$ & $\cdots$ & $\cdots$ \\
\hline $\begin{array}{l}\text { I946 } \\
\text { I947 }\end{array}$ & & & & & & a & $2 \cdot 0$ & $\cdots$ & $\cdots$ & $\cdots$ & $\cdots$ & $\cdots$ \\
\hline $\begin{array}{l}\text { I947 } \\
\text { Av. }\end{array}$ & $\cdots$ & $\cdots$ & 2.0 & 10 & & $\cdots$ & $\cdots$ & $\cdots$ & $\cdots$ & $\cdots$ & $\cdots$ & . \\
\hline Av. & . & I.7 & 19.8 & 25.7 & I9. I & $2 \cdot 9$ & 0.4 & $\cdots$ & $\cdots$ & $\cdots$ & $\cdots$ & . \\
\hline
\end{tabular}

The mean numbers of post-larvae of $G$. minutus (per $\frac{1}{2} \mathrm{hr}$. oblique haul) for each month have been totalled, and averages derived for each month. The result shows clearly that the post-larvae of $G$. minutus occurred only in the hauls of February, March, April, May, June and July. The numbers in February and June were very small and still smaller in July. From the analysis of the ponderal indices it was inferred that the spawning period is from February to May, the height of spawning being in March and April. The number of post-larvae is greatest in April and May. The occurrence of a few post-larvae in June and July may be due to a few late spawners as well as to a few post-larvae being carried over to these months, for there are no data regarding the size of the post-larvae recorded. Thus the post-larvae recorded in the months of June and July may include the slower-growing individuals from earlier spawnings.

When the individual years are considered there is a certain amount of fluctuation in the general picture, the post-larvae occurring earlier in some years 
and later in others. The maximum number of post-larvae occurred in March or April in some years and in May in others. Table XXVII gives the number of times the post-larvae have occurred in the hauls (not numbers of larvae) in individual months during the period under survey.

It is seen from Table XXVI that there has been a gradual decline in the occurrence of post-larvae of G. minutus in Plymouth waters in recent

Table XXVII. Occurrences of Post-Larvae in Particular Months

$\begin{array}{lcc}\text { Month } & \begin{array}{c}\text { No. of } \\ \text { Occurrence }\end{array} & \begin{array}{c}\text { No. of years } \\ \text { covered }\end{array} \\ \text { Jan. } & \circ & \text { II } \\ \text { Feb. } & 4 & \text { I2 } \\ \text { Mar. } & 9 & \text { I2 } \\ \text { Apr. } & \text { I5 } & \text { 16 } \\ \text { May } & \text { I6 } & \text { 16 } \\ \text { June } & 8 & \text { 17 } \\ \text { July } & 4 & \text { I7 } \\ \text { Aug.-Dec. } & \circ & \text { 13-16 }\end{array}$

years. In the collections from the Young Fish Trawl for I948-49 only three post-larvae have been found of $G$. minutus in forty-eight hauls and of these, two post-larvae occurred in April I949 and one in June I948. This decline in the occurrence of post-larvae of G. minutus may be only a part of the general decline of post-larvae of all teleostean fishes in Plymouth waters observed by Russell. This decline is thought to be due to a decrease in the amount of rich Atlantic surface water entering the western channel, so that the more localized stocks of fish have spawned under adverse conditions, resulting from an increased proportion of comparatively impoverished coastal water.

\section{SUMMARY}

The volumetric and qualitative analysis of the food of Gadus minutus has been discussed. The post-larvae feed entirely on copepods, mostly Pseudocalanus elongatus. The O-group feeds on copepods, small decapods, amphipods, polychaetes and isopods. The adolescent and adult groups feed on larger decapods like Processa canaliculata, Galathea spp. and Portunus spp., fish, polychaetes and amphipods.

The age and rate of growth of $G$. minutus have been computed from a study of the supra-occipital crest. These age determinations have been correlated with the age determined by scales, otoliths and size-analysis. Back-calculations have been made by graphical method and by using the Lea-Dahl formula. The differences between the back-calculated lengths and actual observed lengths are negligible.

The spawning period has been determined by analysis of the seasonal fluctuation of the condition factor of the fish. This has been verified by examination of the data on the seasonal abundance of the post-larvae in the Plymouth area. The spawning period is from February to May and the height of spawning is in March and April. 


\section{REFERENCES}

AIKaWa, H., 1938. Age determination of chub-mackerel, Scomber japonicus (Houttuyn). Bull. Fap. Soc. Sci. Fish., Vol. 6, pp. 9-12.

Brown, W. W. \& Cheng, C., I946. Investigations into the food of the cod (Gadus callarias) off Bear Island, and of the cod and haddock (Gadus aeglefinus L.) off Iceland and the Murman coast. Hull Bull. Mar. Ecol., Vol. III, pp. 35-7I.

Chaine, J. \& Duvergier, J., 1927. Distinction des Gadus capelanus, minutus et luscus par leur sagitta. C.R. Acad. Sci., Paris, T. I84, pp. 977-8.

Chevey, P., 1929. Le Tecaud (Gadus luscus). Résumé de nos connaissances actuelles sur ce poisson. Rev. Trav. Off. Pêche. Marit., T. 2, pp. 74-99.

Chugunov, N. I., 1926. Determination of the age and growth-rate of fish by the bones. Siberian Ichthyological Lab. 3372. Krasnoyarsk. (English translation by Mr F. M. Davis). ${ }^{1}$

Corbin, P. G., I948. On the seasonal abundance of young fish. IX. The year I947. fourn. Mar. Biol. Assoc., Vol. xxxvII, pp. 718-22.

CunNingham, J. T., I891. The rate of growth of some sea-fishes and their distribution at different ages. Fourn. Mar. Biol. Assoc., Vol. 2, pp. 95-I40.

Damas, D., I909. Contribution à la biologie des gadides. Cons. Perm. Int. Explor. Mer, Rapp. Proc. Verb., Vol. x, Special Part, B 3, pp. I-227.

Dannevig, A., I933. On the age and growth of the cod (Gadus callarias L.) from the Norwegian Skaggerak coast. Fisk. Skrift. Ser. Havunders. Rep. Norw. Fish. Mar. Invest, Vol. IV, No. I, pp. I-I45.

DAY, FRANCIS, I880-84. The Fishes of Great Britain and Ireland, Vol. I. London.

1888. On the bib (Gadus luscus) and poor-cod (Gadus minutus). Ann. Mag. Nat. Hist., Vol. I, Ser. 6, pp. I5I-4.

EHRENBAUM, E., I9OI-IO. Eier und Larven von Fischen des Nordischen Planktons. - Nordisches Plankton, Lief. x, I905, pp. I-216; 1909, pp. 217-4I3.

FAGE, L., I9I0-II. Le Capelan de la Mediterranée: Gadus capelanus (Risso) et ses rapports avec les espèces voisines: Gadus luscus Linné et Gadus minutus O. Fr. Müller. Arch. Zool. Exp. Gen., Ser. 5, T. vi, pp. 257-282.

ForD, E., I938. Vertebral variation in teleostean fishes. Fourn. Mar. Biol. Assoc., Vol. xxII, pp. I-60.

FRANZ, V. vON, I9IO. Ueber die Ernährungsweise einiger Nordseefische, besonders der Scholle. Wissensch. Meeresunters. Abt. Helgoland, Bd. IX, Heft 2, I4, pp. 197-215.

Fries, B., Ekstrom, C. U. \& Sundervall, C., I892. A History of Scandinavian Fishes. Pt. I, 2nd ed. revised by F. A. Smitt. Stockholm.

Graham, M., I929a. On the collection and preparation of fish scales. Fourn. Cons. Perm. Int. Explor. Mer, Vol. Iv, pp. 339-40.

- I $929 b$. Studies of age determination in fish. Pt. I. Fish. Invest. Min. Agric. Fish, Ser. II, Vol. XI, No. 2. London.

- r 929 c. Studies of age determination in fish. Pt. II. A survey of the literature. Fish. Invest. Min., Agric. Fish., Ser. II, Vol. xI, No. 3. London.

HART, T. J., I946. Report on trawling surveys on the Patagonian continental shelf. Discovery Rep., Vol. xxIII, pp. 223-408.

Hickling, C. F., I927. The natural history of the hake. Parts I and II. Fish. Inv. Min. Agric. Fish., Ser. II, Vol. x, No. 2, Ioo pp. London.

- 1930. The natural history of the hake. Part III. Seasonal changes in the condition of the hake. Fish. Inv. Min. Agric. Fish., Ser. II, Vol. xII, No. I, London.

- 1933. The natural history of the hake. Part IV. Age determination and growthrate. Fish. Inv. Min. Agric. Fish., Ser. II, Vol. xIII, No. 2, I20 pp. London.

${ }^{1}$ I am grateful to $\mathrm{Mr}$ Michael Graham for sending me this paper. 
Hickling, C. F. I940. The fecundity of the herring of the southern North Sea. fourn. Mar. Biol. Assoc., Vol. 24, pp. 619-32.

Hoek, P. P. C., I910. Bericht über Eier und Larven von Gadiden, mit besonderer Berücksichtigung der seit Juli 1908 veröffentlichten Arbeiten über diesen Gegenstand. Cons. Perm. Int. Explor. Mer., Rapp. Proc. Verb., Vol. xII, C, I, pp. I-29.

Johnston, M., I938. Some methods of preparing teleost fish otoliths for examination. fourn. Roy. Micr. Soc., Vol. LVIII, Ser. III, pp. 373-5.

Lebour, M. V., I9I7. The food of post-larval fish. Fourn. Mar. Biol. Assoc., Vol. xI, pp. $433-69$.

— I9I9. The food of young fish. Fourn. Mar. Biol. Assoc., Vol. xII, pp. 26I-324.

LE CREN, E. D., I947. The determination of the age and growth of the perch (Perca fluviatilis) from the opercular bone. Fourn. Anim. Ecology, Vol. I6, pp. I88-204.

Marine Biological Association, 193i. Plymouth Marine Fauna. 2nd ed.

McIntosh, W. C. \& MASTERman, A. T., I897. The Life-Histories of the British Marine Food Fishes. London.

Menon, M. D., I950. The determination of the age and growth-rate in fishes by bones. (In the Press.)

Orton, J. H., 1929. Reproduction and death in invertebrates and fishes. Nature, Vol. cxxxIII, pp. 14-15.

RUSSELL, F. S., I930-47. On the seasonal abundance of pelagic young of the teleostean fishes in the Plymouth area. I-VIII, fourn. Mar. Biol. Assoc., Vols. xvI, pp. 707-22; xx, pp. I47-79; xx, pp. 595-604; XxI, pp. 679-86; XxII, pp. 493-500; xxIII, pp. $38 \mathrm{I}-86$; xxIV, pp. $265-70$; xxvi, pp. $605-8$.

SCHMIDT, JoHs., I902-7. The distribution of the pelagic fry and the spawning regions of the gadoids in the North Atlantic from Iceland to Spain. Cons. Perm. Int. Explor. Mer, Rapp. Proc. Verb. Special Part, B 4, I909, 229 pp.

- I905. The pelagic post-larval stages of the Atlantic species of Gadus. Pt. I. Medd. Kom. Havund. Fiskeri, Bd. I, No. 4.

I906 The pelagic post-larval stages of the Atlantic species of Gadus. Pt. II. Medd. Kom. Havund. Fiskeri, Bd. II, No. 2.

Sund, OsCar, I927. Biological statistics of the stocks of fish. I. The Arcto-Norwegian cod stock. Fourn. Cons. Perm. Int. Explor. Mer, Vol. II, pp. I6I-9.

TÅNING, A. V., I944. Experiments on meristic and other characters in fishes. I. Medd. Kom. Danm. Fisk. Havund. Ser. Fiskeri, Bd. XI, pp. I-66.

Tereschenko, K. K., I917. La brême (Abramis brama L.) de la région du Volga et de la mer Caspienne, son industrie et la biologie. Trav. Lab. Ichth. d'Astrakhan. Vol. IV, Fasc. 2, pp. I-I59. (In Russian.)

Thompson, Harold, I922. Problems in haddock biology. With special reference to the validity and utilisation of the scale theory. I. Preliminary report. Fish. Scot. Sci. Invest. No. v (May I923).

Thompson, WM., I856. The Natural History of Ireland. Vol. Iv. Mammalia, Reptiles and Fishes. London, $156 \mathrm{pp}$.

Thomson, J. S., I902. The periodic growth of scales as an index of age. Fourn. Mar. Biol. Assoc., Vol. vi, N.S., pp. 373-5.

- 1904. The periodic growth of scales in Gadidae as an index of age. Fourn. Mar. Biol. Assoc., Vol. vII, N.S., pp. I-IO9.

Williamson, H. C., I906. On the specific characters of Gadus luscus, Gadus minutus and Gadus esmarcki. Bd. Fish. Scot. Sci. Invest., 24th Rep., pp. II6-40.

YASUDA, H, 1940. On the rings formed on the scale, vertebral centrum and otolith of the same individual fish, Scombrops chilodipteroides and Theragra chalcogramma (Pallas). Bull. Fap. Soc. Sci. Fish. Vol. 8, pp. 298-300. (In Japanese.) 


\section{Appendix. List of Organisms Found in the Stomach Contents OF GADUS MINUTUS}

\begin{tabular}{|c|c|c|c|}
\hline \multirow[b]{2}{*}{ Polychaeta } & \multicolumn{3}{|c|}{ Food of I- to V-Year Groups of Gadus minutus } \\
\hline & $\begin{array}{l}\text { Goniada sp. } \\
\text { Pallasia murata } \\
\text { Amphitrite sp. }\end{array}$ & Decapoda & $\begin{array}{l}\text { Pandalina brevirostris } \\
\text { Hippolyte varians } \\
\text { Spirontocaris cranchi }{ }^{1}\end{array}$ \\
\hline Crustacea & & & Processa canaliculata \\
\hline Copepoda & Calanus finmarchicus & & Crangon vulgaris \\
\hline Cumacea & $\begin{array}{l}\text { Labidocera wollaston } \\
\text { Diastylis sp. }\end{array}$ & & $\begin{array}{l}\text { Philocheras bispinosus } \\
\text { Galathea intermedia }\end{array}$ \\
\hline Leptrostraca & $\begin{array}{l}\text { Diastylis sp. } \\
\text { Nebalia bipes }{ }^{1}\end{array}$ & & $\begin{array}{l}\text { Galathea intermedia } \\
\text { G. dispersa }\end{array}$ \\
\hline Isopoda & Rocinela danmoniensis & & G. strigos $a^{2}$ \\
\hline & Conilera cylindracea & & Munida bamffica ${ }^{1}$ \\
\hline Amphipoda & Orchomenella nana & & Porcellana longicornis \\
\hline & Ampelisca brevicornis & & P. platycheles \\
\hline & A. spinipes & & Upogebia sp. \\
\hline & $\begin{array}{l}\text { A. tenuicornis } \\
\text { A. diadema }\end{array}$ & & Eupagurus bernhardus \\
\hline & $\begin{array}{l}\text { A. dradema } \\
\text { Leucothoë sp. }\end{array}$ & & $\begin{array}{l}\text { E. prideauxi } \\
\text { Portunus pusillus }\end{array}$ \\
\hline & Panoploea minuta & & P. holsatus \\
\hline & Iphimedia obesa & & P. depurator \\
\hline & Urothoë elegans & & Corystes cassivelaunus ${ }^{3}$ \\
\hline & $\begin{array}{l}\text { Monoculodes carinatus } \\
\text { Monoculodes sp. }\end{array}$ & & $\begin{array}{l}\text { Inachus dorsettensis } \\
\text { Macropodia longirostris }\end{array}$ \\
\hline & Apherusa ovalipes & Mollusca & Nucula nitida \\
\hline & Apherusa henneguyi & & Natica catena \\
\hline & Nototropis falcatus & & Turritella communis \\
\hline & Cheirocratus assimilis & & Philine aperta ${ }^{4}$ \\
\hline & Maera othonis & & Heterosepiola atlantica \\
\hline & $\begin{array}{l}\text { Erichthonius brasiliensis } \\
\text { Eurystheus maculatus }\end{array}$ & Echinodermata & $\begin{array}{l}\text { Ophiura texturata } \\
\text { Cucumaria } \text { sp. }^{3}\end{array}$ \\
\hline & Phtisica marina & Fish & Gadus minutus? ${ }^{1}$ \\
\hline & Pseudoprotella phasma & & Callionymus spp. \\
\hline Mysidacea & Leptomysis gracilis & & Crystallogobius nilssoni \\
\hline & Anchialina agilis & & Trigla spp. \\
\hline Euphausiacea & Nyctiphanes couchi & & Ctenolabrus sp. \\
\hline $\begin{array}{l}1 \text { Occu } \\
{ }_{3} \text { Occu }\end{array}$ & rred only once. & only th & $\begin{array}{l}\text { twelve stomachs. } \\
\text { rice. }\end{array}$ \\
\hline
\end{tabular}


Journ. MAR. BIol. Assoc. XXIX (I)

Menon. Plate I
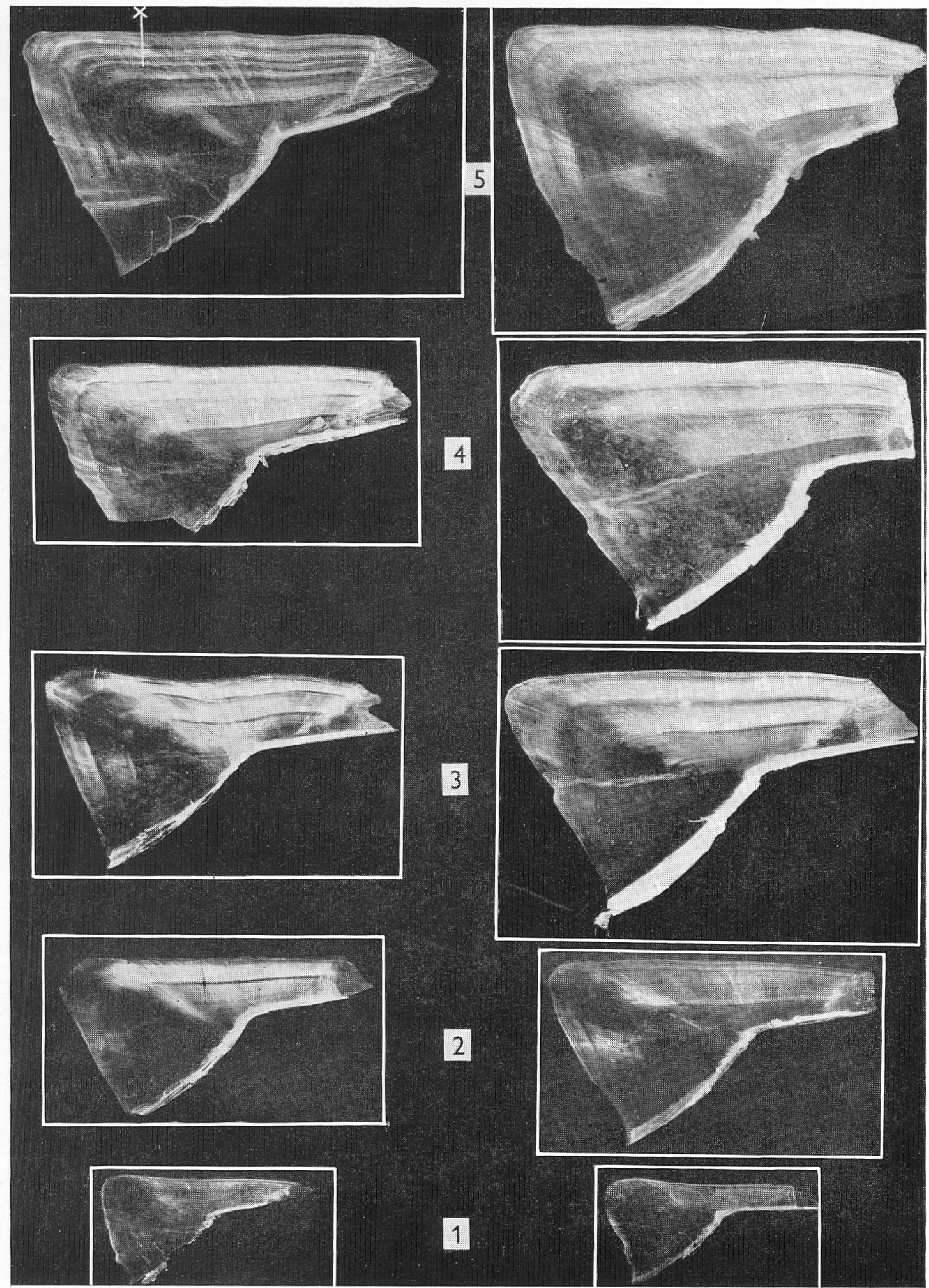

A 


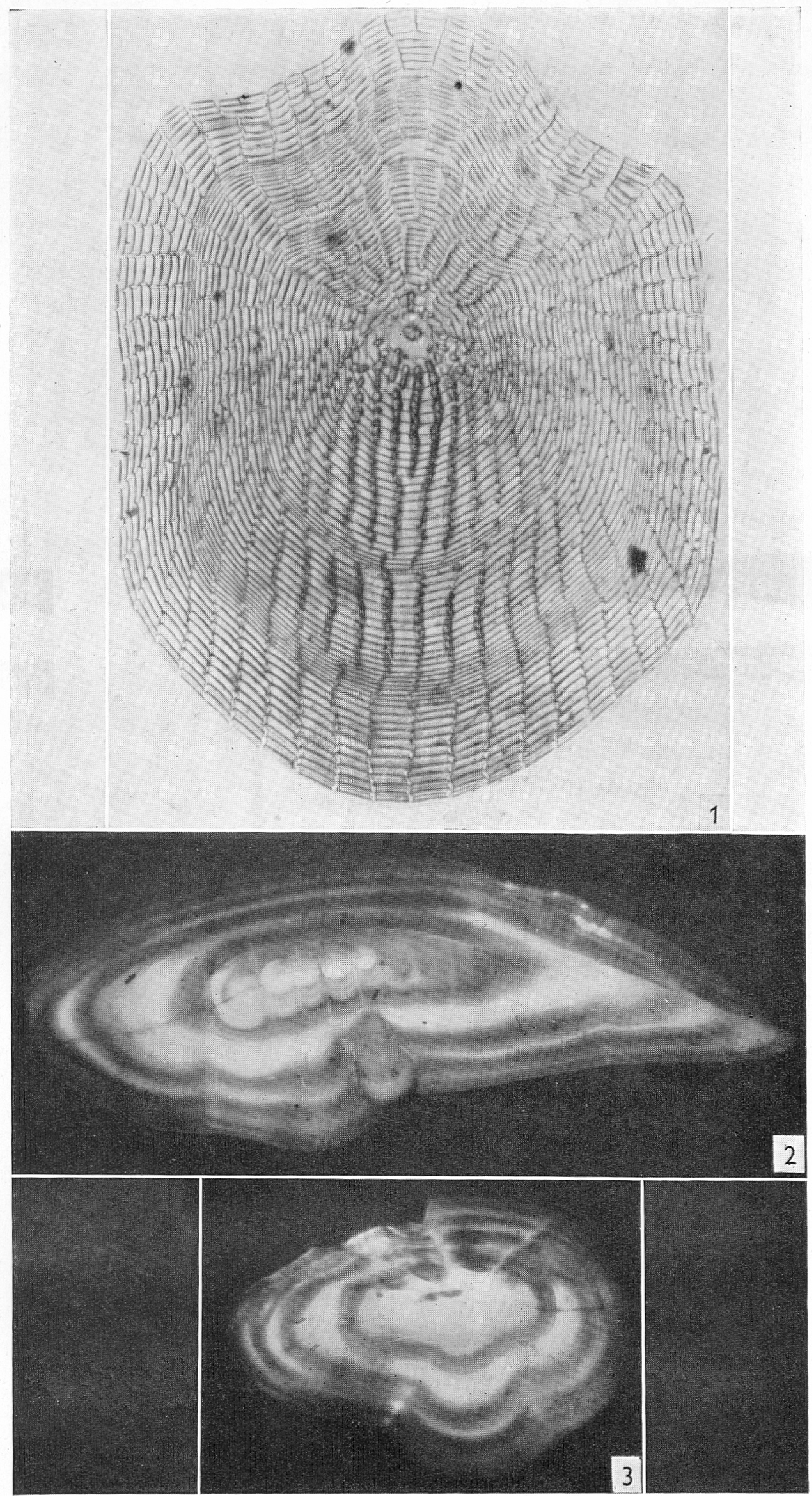

Figs. I-3. 


\section{Food of the O-Group of Gadus minutus}

\begin{tabular}{|c|c|c|c|}
\hline \multirow{6}{*}{$\begin{array}{l}\text { Polychaetes } \\
\text { Crustacea } \\
\text { Copepoda }\end{array}$} & Goniada sp. & Decapoda & $\begin{array}{l}\text { Pandalina brevirostris } \\
\text { Hippolyte varians }\end{array}$ \\
\hline & Calanus finmarchicus & & Small Processa \\
\hline & Pseudocalanus elongatus & & canaliculata \\
\hline & Centropages typicus & & Crangon vulgaris \\
\hline & Temora longicornis & & Philocheras bispinosus \\
\hline & Acartia clausi & & Galathea intermedia \\
\hline Isopoda & Conilera cylindracea & & Small Porcellana \\
\hline Amphipoda & $\begin{array}{l}\text { Small Ampelisca } \\
\text { spinipes and } A \text {.diadema }\end{array}$ & & $\begin{array}{l}\text { longicornis } \\
\text { Eupagurus bernhardus }\end{array}$ \\
\hline & $\begin{array}{l}\text { Apherusa ovalipes } \\
\text { A. henneguyi } \\
\text { Phtisica marina }\end{array}$ & Mollusca & $\begin{array}{l}\text { Small Portunus spp. } \\
\text { Nucula nitida } \\
\text { Natica catena }\end{array}$ \\
\hline Mysidacea & Leptomysis gracilis & & Small Turritella \\
\hline Euphausiacea & Nyctiphanes couchi & & communis \\
\hline
\end{tabular}

\section{EXPLANATION OF PLATES}

Plate I

Ten supra-occipital crests of Gadus minutus photographed against a black background by reflected light. $\times 3.8$.

A, five supra-occipital crests belonging to male Gadus minutus measuring (I) $8.0 \mathrm{~cm}$. - age I;

(2) $12.4 \mathrm{~cm}$. - age 2, just completing the 2nd transparent zone; (3) $14.6 \mathrm{~cm}$. - age 3 ;

(4) $16.5 \mathrm{~cm}$.-age 4 , just completing the 4 th transparent zone; (5) $18.1 \mathrm{~cm}$.- age 5 (the ring marked $X$ is a false one caused by 'doubling': it can be seen that this ring is not complete and becomes continuous with the succeeding transparent zone in the vertical portion of the crest). B, five supra-occipital crests belonging to female Gadus minutus measuring (I) $8.4 \mathrm{~cm}$. - age I; (2) $13.4 \mathrm{~cm}$. - age 2; (3) $16.4 \mathrm{~cm}$. - age 3 ; (4) $18.8 \mathrm{~cm}$. - age 4 ; (5) $2 \mathrm{I} \cdot \mathrm{I} \mathrm{cm}$. - age 5.

\section{Plate II}

Fig. I. A scale from a male Gadus minutus measuring $14.9 \mathrm{~cm}$. The photograph is of an alizarine-stained scale. $\times 42$.

Fig. 2. Longitudinal section of the otolith of a female Gadus minutus measuring $18.8 \mathrm{~cm}$. Four opaque zones and four transparent zones are clearly visible. The 4 th transparent zone is at the margin. This is one of the very few of the older fishes in which the 'age rings' could be so clearly discerned in the otolith. $\times$ II .5 .

Fig. 3. The transverse section of the above same otolith. $\times$ II 5 . 